\title{
Remote Control: Revised Article 9 and the Negotiability of Information
}

\author{
JONATHAN C. LIPSON*
}

This article considers the effect that rules on the continuity of security interests and proceeds under Article 9 of the Uniform Commercial Code will have on the negotiability (i.e., free alienability) of information assets, such as data and biotechnologies. The continuity of interest rules provide that a security interest will presumptively continue in collateral, even after disposition by the debtor. The proceeds rules provide that a security interest will automatically attach to, among other things, "rights arising out of" collateral, and to whatever is received upon the disposition of the collateral.

Information assets, such as data and biotechnology assets, are often highly mobile, mutable and replicable. Thus, security interests in these assets will arise readily and will endure, even as these assets may travel through the chain of commerce, into the hands of good faith purchasers or licensees remote from the debtor and secured party that created the interest in the first place. This article calls the power to assert a security interest in assets at such a remove "remote control."

The article then considers arguments against remote secured party control under these circumstances. Among other things, remote secured party control presents challenges to historic understandings of the treatment of bona fide purchasers, and to doctrinal and theoretical approaches to property.

This article concludes by suggesting that courts can mitigate the problem of remote control by relaxing the definition of property in this context. If data and biotechnology assets are property at all-a contested claim-it is not clear that they should be treated as such for the benefit of remote, prior secured parties in disputes with later bona fide purchasers.

* Assistant Professor of Law, University of Baltimore School of Law. A prior draft of this paper was presented at the Arthur Moller Workshop at the University of Texas in November 2001. Jay Westbrook and the other talented participants at that workshop provided valuable comments on this article. I have also benefitted from the comments of, or discussions with, Hanoch Dagan, Steve Harris, Rebecca Huss, Ted Janger, Kathleen Noonan, and David Snyder. You can reach me at 410-837-4054 or jlipson@ubmail.ubalt.edu. Phil Karasik and Richard Smith provided valuable research assistance with this article. Errors and omissions are mine, alone. Copyright $\odot 2002$ by Jonathan C. Lipson. 


\section{TABLE OF CONTENTS}

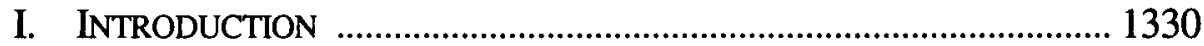

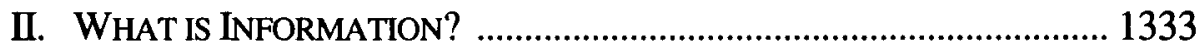

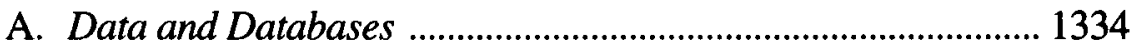

B. Biotechnologies ........................................................................... 1336

III. MODELS AND THEORIES OF NEGOTIABILITY .................................. 1339

A. Models of Negotiability .......................................................... 1339

1. "Strong Negotiability"-The Negotiable Instrument ....... 1339

2. "Weak Negotiability"-General Intangibles .................... 1343

B. Theories of Negotiability ............................................................. 1345

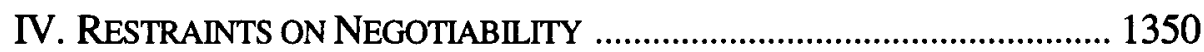

A. Property Rules ....................................................................... 1350

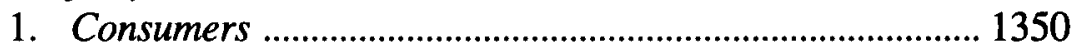

2. Commercial Usage ............................................................ 1352

a. Trade Secret ............................................................. 1353

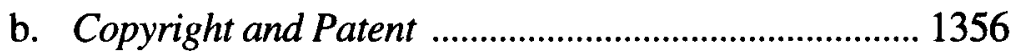

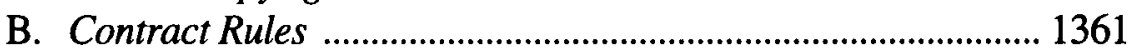

C. Regulatory Restraints .............................................................. 1366

V. REMOTE CONTROL-ARTICLE 9 AND THE

NEGOTIABILITY OF INFORMATION ................................................. 1369

A. Article 9 as Restraint on Negotiability ..................................... 1369

1. Rule of Effectiveness ............................................................ 1370

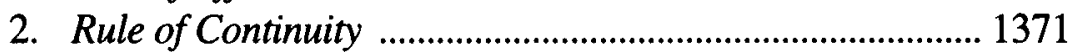

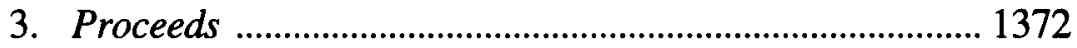

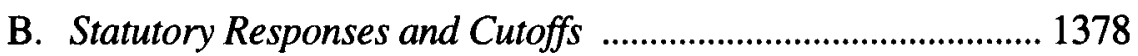

1. Licensee in Ordinary Course ........................................... 1379

2. Nonexclusive License ............................................................ 1381

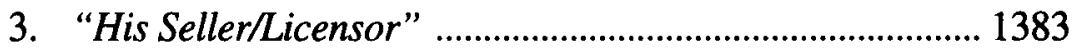


VI. THREE ARgUMENTS AgAINST ARTICLE 9 REMOTE CONTROL ....... 1388

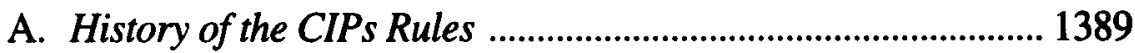

1. Continuity of Interest of Rules .............................................. 1389

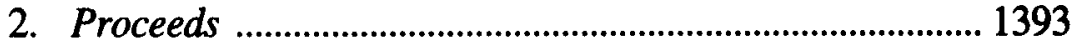

B. The Full Priority Debate ........................................................ 1404

C. CIPs Rules and Recent Property TheoryThe Strategies of the Anticommons ............................................. 1410

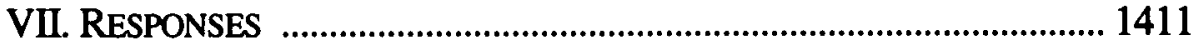

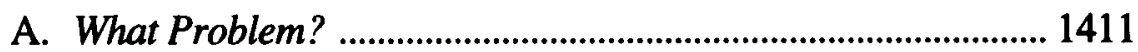

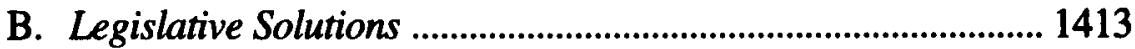

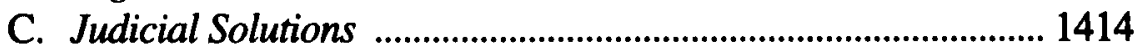

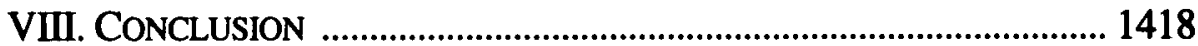


[W] henever any kind of property came into the market-that is, became the subject of a large volume of transactions either of outright sale or of transfer for security-then that kind of property sooner or later acquired some or all of the attributes of negotiability: commercial property must be freely transferable ....

The cereal you ate for breakfast this morning was probably covered with security interests. Yuk! ${ }^{2}$

\section{INTRODUCTION}

As information-whether customer spending habits or genetic codebecomes increasingly valuable, fights about its negotiability will become increasingly fierce. In this context, negotiability simply means free alienability: Can A sell (negotiate) information about B to C, free of claims that B (or anyone else) may have to the information?

Others have written at length about the claims that the Bs of the world have to information about themselves, on theories of privacy, property, tort and contract. ${ }^{3}$ This article assumes as its starting point that, one way or another, the As of the world will overcome most of these obstacles and will have the right to traffic in information about the Bs of the world. This article considers, instead, the powerful, but rarely considered, restraints created by Article 9 of the Uniform Commercial Code.

Article 9 governs secured transactions-transactions in which personal property secures payment or performance of an obligation. ${ }^{4}$ Like the rest of the U.C.C., Article 9 (which has recently undergone a significant revision ${ }^{5}$ ) attempts to strike a balance on negotiability. In general, property that is subject to a security interest (in technical terms, "collateral") remains subject to the security interest notwithstanding sale, exchange, or other disposition. ${ }^{6}$ Thus, in general, Article 9 collateral is not freely negotiable. So, for example, if a debtor (D) granted a security interest in an electronic list of its customers, which was bought or licensed by another business $\left(\mathrm{B} / \mathrm{L}^{1}\right)$, the security interest should follow the list into the computer of that buyer $\left(\mathrm{B} / \mathrm{L}^{1}\right)$. At least in theory, the secured party (SP)

${ }^{1}$ Grant Gilmore, The Good Faith Purchase Idea and the Uniform Commercial Code: Confessions of a Repentant Draftsman, 15 GA. L. REV. 605, 611 (1981).

2 Lynn LoPuCki et al., Commercial Transactions: A Systems ApProach 804 (1998).

${ }^{3}$ See discussion at Part IV, infra.

${ }^{4}$ See U.C.C. \& 1-201(37) (2001) (defining "security interest").

${ }^{5}$ Revised Article 9 has been enacted in all states, and in most went into effect July 1 , 2001. See NCCUSL-Introductions \& Adoptions of Uniform Acts, at http://www.nccusl.org/ nccusl/uniformact_factsheets/uniformacts-fs-ucca9.asp.

$6 \S 9-315(a)(1)(2001)$. 
would have the right to "take" the list from $B / L^{1}$ if $D$ failed to satisfy its obligations to SP.

This general rule is, however, subject to an important exception: A party that acquires collateral "in ordinary course" takes its rights in the collateral free of the security interest. ${ }^{7}$ The ordinary course model was developed with a specific kind of collateral in mind-"goods." Goods is the term Article 9 uses to describe most tangible personal property. ${ }^{8}$ Although not without its critics, the ordinary course model as applied to goods seems to have worked reasonably well. ${ }^{9}$ The problem is that most information assets will not be "goods," but rather will be "general intangibles." 10 General intangibles-such as information-are subject to the same ordinary course model. But here, the model will break down for at least four reasons. ${ }^{11}$

First, the ordinary course rules will only apply to "nonexclusive licenses" of general intangibles. ${ }^{12}$ It is not at all clear what a "license" is, much less what would make one "nonexclusive" for this purpose. It is, however, clear that the security interest would not be cut off on an outright sale of information assets, no matter how "ordinary course" the transaction.

Second, the ordinary course rules will cut off a security interest only when the licensor/debtor is "in the business" of licensing general intangibles of "that kind." 13 If the licensor happens to be in another business, it will probably not be in the business of licensing intangibles. So, for example, if $\mathrm{D}$ were a retailer of toys that happened to develop a valuable customer list, its granting of a license to $\mathrm{B} / \mathrm{L}^{1}$ to use that list would probably not be "ordinary course." This is because $\mathrm{D}$ is not "in the business" of generating customer lists; it sells toys. ${ }^{14}$ This means that the ability to acquire information free of the prior security interest turns not on the good faith of the buyer/licensee, but instead on the practices of the seller/licensor.

A third class of restraint arises from the so-called "created by his seller" rule. ${ }^{15}$ Under this rule, even an ordinary course disposition will be free only of the security interest created by the immediate debtor that disposed of the collateral.

${ }^{7}$ See id. $\$ \$ 9-320,-321$ (2001) (setting forth "ordinary course" rules).

${ }^{8}$ See id. §9-102(a)(44) (2001) ("“Goods' means all things that are moveable when a security interest attaches.").

${ }^{9}$ A critical history of the development of the ordinary course model appears in Part VI.A, infra.

${ }^{10}$ This is so for Article 9 purposes. As discussed in Part IV.B below, a line of cases from the Seventh Circuit may cast some doubt on this characterization for other purposes.

11 See § 9-102(a)(42) (2001) (defining "general intangibles").

12 See id. \& 9-321(b) (2001).

13 See id. $\$ 9-321$ (a) (2001).

14 This, of course, describes at least part of the problem in Federal Trade Commision v. Toysmart.com, $L . L C$., discussed in Part IV.C, infra.

15 §-321(a) (2001). 
Security interests in the same property created by someone prior in the chaine.g., a prior seller or licensor-would not be discharged.

Assume, for example, that $\mathrm{B} / \mathrm{L}^{1}$ was not another retailer, but instead was a data aggregator, which routinely purchased (or licensed) customer lists from the Ds of the world, and then resold (or relicensed) them. $\mathrm{B} / \mathrm{L}^{1}$ would, in other words, be "in the business" of licensing "general intangibles" of "that kind," meaning lists of retail customers. If $B / L^{2}$ purchased or licensed the list of $D$ 's customers from $B / L^{1}$ (perhaps commingled with names $B / L^{1}$ obtained from other debtors), $B / L^{2}$ might (reasonably) assume that it acquired the list free of any encumbrances, assuming that it searched the public U.C.C. records for encumbrances against $\mathrm{B} / \mathrm{L}^{1}$ 's property, and found none. $\mathrm{B} / \mathrm{L}^{2}$ would, however, be wrong. Even though "ordinary course," $B / L^{2}$ 's transaction was with $B / L^{1}$, not $D$, the party that created the security interest. It was therefore not "his $\left[B / L^{2}\right.$ 's] seller or licensor"16 that created the security interest; it was D, a party prior in the chain of production. Worse, there is virtually no way that $B / L^{2}$ could have discovered SP's security interest. $B / L^{2}$ would have had no reason to search the public records against $D$, the party that created the security interest. $B / L^{2}$ may not even know that $D$ exists.

Article 9's fourth class of restraint will arise by virtue of the rules on "proceeds." Proceeds include - among many other things-"whatever is acquired upon ... disposition of collateral."17 Thus, even if D only grants a security interest in its inventory (the goods that it sells to customers), SP would have a security interest in the customer list if, as is highly likely, D acquired the names of its customers "upon disposition" of D's collateral (inventory). The customer list sold to $B / L^{1}$, in other words, would be proceeds of the inventory sold by $D$, and therefore also subject to SP's security interest.

The proceeds security interest is not limited to collateral in the hands of the debtor. If the first buyer from $D\left(B / L^{1}\right)$ sold or licensed the collateral to a second buyer $\left(B / L^{2}\right), B / L^{1}$ would then hold proceeds of the original collateral. If $B / L^{2}$ sold or licensed the collateral to a third buyer $\left(\mathrm{B} / \mathrm{L}^{3}\right), \mathrm{B} / \mathrm{L}^{2}$ would hold proceeds, and so on, ad infinitum, all the way to a buyer/licensee I will characterize as $\mathrm{B} / \mathrm{L}^{\infty}$. "[O]f course," the official comments tell us, the secured party "may have only one satisfaction." 18

The proceeds rules as applied to information technology and biotechnology assets could create even greater problems than the continuity of interest rules. Revised Article 9 has significantly expanded the definition of proceeds, to capture virtually all rights and value incident to the original collateral. ${ }^{19}$ Thus, data collected by a retailer should be proceeds of the goods sold; licenses of software

\footnotetext{
${ }^{16} \mathrm{Id}$.

17 § 9-102(a)(64)(A) (2001).

$18 \mathrm{Id}$ § 9-315 cmt. 2 (2001).

${ }^{19}$ See id. § 9-102(a)(64) (2001).
} 
should be proceeds of the copyright that protects the software; organs grown from stem cells should be proceeds of both the stem cells themselves and the patent or other intellectual property governing the creative process. A proceeds security interest can arise without warning, and will, by virtue of the continuity of interest rules, likely continue long after the proceeds leave the debtor. And, because proceeds need not be "received by the debtor," the secured party should be able to pursue these assets no matter who has them or how they were acquired.

Thus, the problem of remote control: the unique power created by Article 9 to assert rights in assets in the hands of parties far removed from the original debtor, in a transaction that is likely undiscoverable by that remote party.

A reflexive response may be to point out that those who develop and traffic in information assets do not generally grant security interests in their assets for a variety of reasons, including that they do not finance their operations with borrowed money. Rather, most technology-oriented businesses are financed with equity capital investments that do not come with security interests in personal property of the firm. Thus, none of the rules described above on the continuity of security interests or proceeds (which I will call collectively the "CIPs Rules") would attach to the assets of most technology-oriented firms.

While this may be true, two facts must be considered. First, as information assets become more stable sources of value-as they become more obviously commercial property-they will increasingly become collateral for Article 9 security interests. Second, and more importantly, the CIPs Rules are both covert and resilient. Thus, even if the technology firm itself grants no security interests in its assets, it may well unwittingly acquire information assets that are subject to security interests of which it does not and (realistically) cannot know. These encumbrances will continue in the information assets as acquired and negotiated by the firm, notwithstanding the good faith of the firm or its customers.

This article examines Article 9's effect on the negotiability of information assets. Part II surveys briefly two types of information assets that will likely be important in this context, data and biological information. Part III then considers models and theories of negotiability, with a special emphasis on the treatment of bona fide purchasers (BFPs). Parts IV and V focus, respectively, on restraints on negotiability outside and within Article 9. Part VI marshals historical and theoretical arguments against Article 9's restraint on the negotiability of information. Part VII offers a solution to the problem of remote secured party control through a careful assessment of the role of property doctrine in transactions in information assets.

\section{WHAT IS INFORMATION?}

Information-as-asset is hardly new. Those in business have long understood that know-how, trade-secrets, facts, figures, patents, copyrights and so on have great value. New technologies and new markets, however, have significantly 
transformed the collection, manipulation, and distribution of information. As Amelia Boss, a leading writer on commercial uses of technology, recently put it: "With the advent of the Internet and the rise of computer technologies generally, we have witnessed the commoditization of information: Information itself has become the subject of commercial transactions, not just the medium for performing them."20

Two general classes of information assets will be especially valuable: databases and biological information. ${ }^{21}$ These two classes of assets will, by virtue of new technologies and markets, share three important characteristics: (i) high mobility; (ii) ready mutability; and (iii) virtually limitless replicability. All three traits will, not surprisingly, matter greatly both to those who traffic in these assets and the secured parties who, wittingly or not, acquire security interests in them.

\section{A. Data and Databases}

The most obvious store of information is the electronic database, a digitized collection of associated facts. ${ }^{22}$ It is estimated that every individual in the United States may be listed on scores, perhaps hundreds, of databases at any given time. ${ }^{23}$ Valuable data often reflect consumer buying habits. In the bankruptcy of toysmart.com, for example, the debtor sought to sell its computerized customer list, despite having promised on its website that it would not do so. ${ }^{24}$ The same occurred in the more recent bankruptcy of Egghead.com. ${ }^{25}$

Valuable data are not simply discrete facts about individuals. Data may also be proprietary information about a trading partner's spending habits, product designs, or finances, all of which may be acquired through Electronic Data Interchanges (EDI), business-to-business web sites (B2B), business-to-consumer exchanges (B2C), or private business exchanges. EDI "is the movement of electronic business messages, such as purchase orders, from computer to computer." 26 B2Bs are business-to-business electronic marketplaces that use the

20 See Amelia H. Boss, Taking UCTTA on the Road: What Lessons Have We Learned?, 7 ROGER WILLIAMS U. L. REV. 167, 170 (2001).

${ }^{21}$ As discussed below, these two obviously overlap: many databases contain biological information (e.g., the Human Genome).

22 See, e.g., J.H. Reichman \& Pamela Samuelson, Intellectual Property Rights in Data?, 50 VAND. L. REV. 51, 64 (1997) (citation omitted).

23 See Jeff Sovern, Opting In, Opting Out, or No Options at All: The Fight for Control of Personal Information, 74 WASH. L. REV. 1033, 1036 (1999).

24 See Fed. Trade Comm'n v. Toysmart.com, L.L.C., No. Civ. A. 00-CV11341RGS, 2000 WL 1523287, at *1 (D. Mass. Aug. 21, 2000).

25 Troy Wolverton, Egghead Sale Could Crack on Privacy Issues, CNET NEws.COM, at http://news.cnet.com/news/0-1007-200-6962164.html (Aug. 24, 2001).

26 JANE KAUfFMAN WinN, The LAW OF ELECTRONIC COMMERCE $\$ 2.05$ (2000); see also 
Internet to connect businesses to each other electronically. ${ }^{27}$ Private business exchanges are similar to B2Bs but involve only selected business partners. ${ }^{28}$

As has been well explained elsewhere, digital data differ from older forms of information in three ways. First, it is highly mobile, often traveling with the aid of "bots" or other digital agents. ${ }^{29}$ Second, databases can be readily "mined" or manipulated through the use of extraction tools. 30 Third, "works in digital form are vulnerable to uncontrolled replication and dissemination in networked environments." 31 Although these features dramatically enhance the value of electronic data, ${ }^{32}$ they also present unique challenges, both to the regimes that

The Elec. Messaging Servs. Task Force, The Commercial Use of Electronic Data Interchange-A Report, 45 BUS. LAW. 1645, 1649 (1990).

27 See Fed. TRADE COMM'N, ENTERING THE 21ST CENTURY: COMPETTTION POLICY IN THE WORID OF B2B ELECTRONIC MARKETPLACES 2 (Oct. 2000), available at http://www.ftc.gov/os/2000/10/b2breport.pdf (last visited Nov. 6, 2002).

${ }^{28}$ See Nicole Harris, "Private Exchanges" May Allow B-to-B Commerce to Thrive After All, WALL ST. J., Mar. 16, 2001, at B1. Some have noted that B2Bs have not paid off. See Time to Rebuild, ECONOMIST, May 19, 2001, at 55 ("The once promising field of business-tobusiness exchanges is in turmoil."). Nevertheless, it is clear that the exchange of digitized information in one way or another will be critical to future economic development. See The Beast of Complexity, EconomisT, Apr. 14, 2001, Special Section: The Age of The Cloud, at 3-4 (discussing possible migration of software and data to "Internet-borne cloud of electronic offerings").

${ }^{29}$ Stephen T. Middlebrook \& John Muller, Thoughts on Bots: The Emerging Law of Electronic Agents, 56 Bus. LAW. 341, 342 (2000).

30 See Gregory M. Hunsuker, The European Database Directive: Regional Stepping Stone to an Intemational Model, 7 FordHAM INTELL. PROP. MEDIA \& ENT. L.J. 697, 700 (1997).

${ }^{31}$ See Reichman \& Samuelson, supra note 22, at 108 n.258 (quoting Pamela Samuelson, Technology Protection for Copyrighted Works (Feb. 22, 1996) (paper presented to the Thrawer Symposium, Emory Law School)).

32 Professor Perritt has developed a ten-part taxonomy of the value typically associated with information assets, including those in electronic form:

(1) authorship;

(2) chunking and tagging (delineating sections, paragraphs, other boundaries);

(3) internal pointers (tables of contents and indices);

(4) external pointers (bibliographies, footnotes);

(5) presentation of information;

(6) duplication of information product;

(7) distribution of information product;

(8) promotion of product;

(9) billing for products; and

(10) integrity assurance.

See Henry H. Perritt, Jr., Tort Liability, The First Amendment, and Equal Access to Electronic Networks, 5 HARV. J.L. \& TECH. 65, 68-69 (1992) (discussing the role of the "modem print publisher"). 
have historically governed these kinds of assets, and to other related regimes, such as those at commercial law. ${ }^{33}$

\section{B. Biotechnologies}

Electronic databases are not the only form of information asset likely to present challenges to negotiability. Biotechnologies, and especially their informational infrastructure, are also likely to become part of the stream of commerce. $^{34}$

We tend to think of transactions in biological materials as donative, but this assumption masks a significant and well-established commercial component. ${ }^{35}$ Transplants of whole organs $s^{36}$ and tissues ${ }^{37}$ have gone on for some time..$^{38}$

33 As to the challenges presented to the traditional regimes (usually characterized as intellectual property), see Reichman \& Samuelson, supra note 22.

34 See, e.g., Julia D. Mahoney, The Market for Human Tissue, 86 VA. L. REv. 163, 164 67 (2000) (defending use of market principles in human tissues). Compare E. RICHARD GOLD, BODY PARTS: PROPERTY RIGHTS AND THE OWNERSHIP OF HUMAN BIOLOGICAL MATERIALS 177 (1996) (arguing for the rejection of "property-law analysis" for the human body and its components), Leon R. Kass, Organs for Sale? Propriety, Property, and the Price of Progress, 107 PUB. INT. 65, 65 (1992) (claiming "impropriety" of discussing markets in human materials), and Thomas $\mathrm{H}$. Murray, On the Human Body as Property: The Meaning of Embodiment, Markets and the Meaning of Strangers, 20 U. MICH. J.L. REFORM 1055, 1088 (1987) (asserting that human body components should not be regarded as "commodityproperty"), with Gloria J. Banks, Legal and Ethical Safeguards: Protection of Society's Most Vulnerable Participants in a Commercialized Organ Transplantation System, 21 AM. J.L. \& MED. 45, 46 (1995) (arguing for the need for legal safeguards to protect potentially "vulnerable" organ donors), Gregory S. Crespi, Overcoming the Legal Obstacles to the Creation of a Futures Market in Bodily Organs, 55 OHIO ST. L.J. 1, 6, 10-17 (1994) (tracking the history of organ donation law and arguing in favor of a "futures market" for organ transplants), Michelle Bourianoff Bray, Note, Personalizing Personalty: Toward a Property Right in Human Bodies, 69 TEX. L. REV. 209, 210 (1990) (arguing for the creation of a limited legal property right in the human body), and Susan Hankin Denise, Note, Regulating the Sale of Human Organs, 71 VA. L. REV. 1015, 1016 (1985) (suggesting the creation of a properly regulated organ market).

35 Although it sounds new-fangled, transactions in biological materials have been a feature of our economy for many years. Louis Pastuer, for example, sought and obtained a patent on a yeast. See Robert L. Baechtold et al., Property Rights in Living Matter: Is New Law Required?, 68 DENV. U. L. REV. 141, 143 (1991) (citing U.S. Patent No. 141,072).

36 An organ is a part of the body having a special function as part of an integrated living system. TABER's CYCLOPEDIC MEDICAL DiCTIONARY 1368 (Clayton L. Thomas ed., 17th ed. 1993). Vital organs include the heart, lung, liver, pancreas, stomach, and kidneys. The comea, which is often discussed separately from other organs, is a thin clear tissue that covers the iris.

${ }^{37} \mathrm{~A}$ tissue is a group or collection of similar cells and intercellular substance that acts together in the performance of a particular function. The primary tissues are epithelial, connective, skeletal, muscular, glandular, and nervous. Id. at 2000. 
"Donors" have long been paid for their "donations." ${ }^{39}$ Like the acquisition fees paid for organs, private ova donation agencies typically pay for the "time and inconvenience" involved in the "donative" process. ${ }^{40}$ And then there are the regenerative tissues, the most notorious of which is the embryonic stem cell, a primitive, self-regenerating cell from which a variety of biological materials may be grown or manufactured. 41

While there is strong evidence of the commercialization of biological materials, the more profound shifts, both scientifically and economically, appear to be occurring at the informational level. Indeed, control of the human genome may render the more traditional transactions in human materials-organ transplants, tissue donations, and so on-quaintly inefficient. The goal of genetic engineering is not necessarily to make products of processes, but to gain control of the informational foundations of these things. ${ }^{42}$ At this level, disputes will ultimately be about information: both the genetic code that describes our biological construction and the various categories of intellectual property that protect rights in it ${ }^{43}$

The best known example of this endeavor is the Human Genome Project, the mapping and sequencing of the human genetic construct. ${ }^{44}$ The leading private

38 Doctors in the Soviet Union conducted the first kidney transplant in 1936, using a cadaver. Curtis E. Harris \& Stephen P. Alcom, To Solve a Deadly Shortage: Economic Incentives for Human Organ Donation, 16 Issues L. \& MED. 213, 214 (2001). The first successful live kidney transplant was accomplished in the United States in 1956; the first successful heart transplant was accomplished in South Africa in 1967. Id.

${ }^{39}$ Mahoney, supra note 34 , at $170-71$ (citing RichaRd M. TtTmuss, THE GIFT RelationshIP: From Human BloOd to Social POliCY 100, 113 (1971) (blood); Russell SCOTT, THE BODY AS PROPERTY 180, 211 (1981) (hair and sperm)).

${ }^{40}$ See Harris \& Alcom, supra note 38, at 218 (observing that women who "donate" ova receive between $\$ 5,000$ and $\$ 8,000$ per donation).

41 See Molecular Cell Biology 215 (Harvey F. Lodish et al. eds., 3d ed. 1995). Embryonic stem cells, unlike the more differentiated adult stem cells or other cell types, have the ability to develop into a wide variety of cell types. See NAT'L BIOETHICS ADVISORY COMM., ETHICAL IsSUES IN HUMAN STEM CELL RESEARCH: EXECUTIVE SUMMARY 1-2 (1999).

42 Michael D. Davis, The Patenting of Products of Nature, 21 RUTGERS COMPUTER \& TECH. L.J. 293, 308 (1995) (arguing that biotechnology companies seek to control channels of scientific innovation rather than products).

43 See LeSTER C. THUROW, BUILDING WEALTH 116-129 (1999) (arguing that the current intellectual property regime cannot address the needs of the biotechnology industry); Michael A. Heller \& Rebecca S. Eisenberg, Can Patents Deter Innovation? The Anticommons in Biomedical Research, 280 SCIENCE 698 (1998).

44 See Sonia Suter, Genetic Testing and the Use of Information, 41 JURIMETRICS J. 261, 262 (2001) (book review) (arguing that information obtained through the Human Genome Project "can be of great value to those who want to use it to make reproductive or health-care decisions and of detrimental value if used to deny access to insurance, employment, or other societal benefits"). 
company mapping the human genome is Celera Genomics, which was established in May 1998 by the PE Corporation and J. Craig Venter, Ph.D., a leading genomic scientist and founder of The Institute for Genomic Research (TIGR). ${ }^{45}$ Celera announced its first assembly of the human genome on June 26, 2000. The company began the analysis or annotation phase at that time and published the human genome in Science in February 2001. Celera claims to be "the only genomics firm that is using its sequencing power to directly sequence the human genome."46

As an "information company," Celera claims that its mission is to "assist researchers in academia and industry." 47 It apparently provides this assistance by patenting the genes it maps and selling subscriptions to its databases of gene sequence data. ${ }^{48}$ Database subscribers will, according to the company, be primarily pharmaceutical and biotech companies. ${ }^{49}$ As Celera's databases expand beyond genomic sequence data and related annotation to include protein structure and function and metabolic pathways, Celera believes that researchers will use the databases to understand and control body functions at the genetic level. ${ }^{50}$

Biotechnology assets, and especially bioinformation assets, present many of the same challenges as found with data. These challenges include mobility, mutability and replicability. ${ }^{51}$ And, as with data, most legal attention to biotechnology assets focuses on the intellectual property rights and normative aspects of these technologies. Nevertheless, as with data, there seems to be

45 Celera, Company Information: Celera Business and Strategy Questions, at http://www.celera.com/company/home.cfm?ppage=overview\&cpage=faq (last visited Oct. 26, 2002).

46 Id.

${ }^{47}$ Id.

$48 \mathrm{Id}$.

${ }^{49}$ According to Celera, as of September 20, 2001, its 160 customers included "leading companies such as American Home Products, Pfizer, Amgen and Takeda, and prestigious academic and research institutions such as the National Cancer Institute, University of Oxford in England, and Harvard University." Celera, supra note 45.

50 According to the company, "Celera's human and mouse reference genomes with sequence and annotation tracking are fundamental for life science research, allowing researchers to bypass the intense data gathering stage and ask the higher level questions." Celera, Company Information: Overview, at http://www.celera.com/company/home.cfm? ppage=overview\&cpage=default (last visited Oct. 26, 2002).

A new, and perhaps more vital, twist is the rise of "bioinformatics," "the science of using information to understand biology." See Charles Vorndran \& Robert L. Florence, Bioinformatics: Patenting the Bridge Between Information Technology and the Life Sciences, 42 IDEA 93, 94 (2002). Bioinformatics uses "computers and computer related tools for the management of biological information." Id. at 95 .

51 See Baechtold, supra note 35, at 145 ("One of the more troublesome issues relates to protection of the patent holder's rights when the invention is capable of propagation."). 
significant and growing pressure to increase the flow of traffic in bioinformation assets for any number of legitimate reasons, from saving lives to reducing healthcare costs. Saying that there is pressure to increase the volume of transactions in these materials, however, is simply another way of saying that there is increasing pressure to maximize their negotiability.

\section{MODELS AND THEORIES OF NEGOTIABILITY}

Before considering restraints on the negotiation of information-and in particular, the restraints imposed by U.C.C. Article 9-it may be worth exploring what "negotiability" means.

\section{A. Models of Negotiability}

There are many models of negotiability. The U.C.C. alone recognizes a kind of negotiability in section $2-403$, permitting the negotiability of goods free of prior claims and interests; section 3-201, regarding negotiable instruments; sections 7-501 and 7-502, regarding negotiable documents of title to goods; sections 8-302 and 8-303, regarding investment securities; and sections 9-320 and 9-321, regarding property subject to a security interest.

At a higher level of generality, there are two models of negotiability, the "strong" and the "weak." Strong negotiability is represented by the U.C.C. Article 3 negotiable instrument, where a bona fide purchaser of a qualifying piece of paper (a "negotiable instrument") may acquire it free even of prior claims that the paper was stolen. The "weak" model has historically been associated with intangible property, and tends to respect the rights of prior claimants in the property as against the rights of BFPs.

\section{1. "Strong Negotiability"-The Negotiable Instrument}

The strongest, and best developed, model of negotiability is that of the "negotiable instrument." Under U.C.C. Article 3, a "negotiation" occurs whenever there is a legally effective transfer of a "negotiable instrument," a special kind of paper evidencing a monetary undertaking (e.g., a check or promissory note).$^{52}$ Grant Gilmore, a principal architect of Article 9 and leading authority on the U.C.C., once observed that the terms " [n]egotiable' and

52 U.C.C. § 3-201 (2001). Strictly speaking, a negotiation is "a transfer of possession, whether voluntary or involuntary, of [a negotiable] instrument by a person other than the issuer to a person who thereby becomes its holder." Id. A "holder" is defined in U.C.C. section 1201(20) (2001) as "the person in possession if the [negotiable] instrument is payable to bearer or, in the case of an instrument payable to an identified person, if the identified person is in possession." 
'negotiability' are words rarely, if ever, defined." 53 Despite this, in the 1950s, Professor Gilmore developed a useful taxonomy of the attributes of negotiability:

- First, the rights in question (as embodied in the paper) must be "freely assignable; no restraints on alienation will be tolerated." 54

- Second, underlying obligations (i.e., debts) must be "'merged' into the paper evidencing the claim." 55 Thus, the paper itself in many respects embodies the underlying claim. ${ }^{56}$

- Third, the holder of the rights (i.e., the holder of the negotiable instrument) "receives the benefit of a series of presumptions which cast on the defendant the greater part of the burden of proof normally carried by plaintiffs in contract actions." 57

- Fourth, the holder would on default have an automatic right of recourse against prior owners (indorsers) of the paper..$^{58}$

- Fifth, the purchaser of the paper enjoys "bona fide purchaser" status so long as the purchaser "subjectively" is honest "at the time he takes the paper; he is under no duty of inquiry; he may even have 'forgotten' relevant information."59 The purchaser would then be known as a

${ }^{53}$ Grant S. Gilmore, The Commencial Doctrine of Good Faith Purchase, 63 YALE LJ. 1057,1063 (1954) ("They mean not one but many things.").

54 Id. at 1064 .

55 Id. Today, the free negotiability of commercial paper is assured by U.C.C. section 3206 (2001), which provides that an indorsement "limiting payment to a particular person or otherwise prohibiting further transfer or negotiation of the instrument is not effective to prevent further transfer or negotiation of the instrument."

${ }^{56}$ Gilmore, supra note 53 , at 1064 . Today, the merger rule is effectively embodied in U.C.C. section 3-310 (2001), which suspends the underlying obligation when a negotiable instrument is given for the obligation. U.C.C. sections 3-310 and 3-601 to 3-605 (2001) set forth rules on the discharge of obligations embodied in the instrument as well as the underlying obligation that gave rise to the negotiable instrument.

57 Gilmore, supra note 53 , at $1064-65$.

58 ld.

59 Id. at 1065 . The holder in due course doctrine has been limited to some extent. "Good faith" is now defined under Article 3 to include an objective component- "the observance of reasonable commercial standards of fair dealing." U.C.C. § 3-103(a)(4) (2001). In addition, the holder in due course doctrine has been essentially eliminated in consumer debt transactions by virtue of Federal Trade Commission regulations which require that promissory notes contain a legend stating that "[a]ny holder of this consumer credit contract is subject to all claims and defenses which the debtor could assert against the seller of goods and services obtained pursuant hereto." 16 C.F.R. $\$ 433.2$ (a) (2001). Finally, there have been occasional cases holding that willful ignorance will not be tolerated, at least in the consumer context. See, e.g., Gen. Inv. Corp. v. Angelini, 278 A.2d 193, 197 (N.J. 1971) (denying holder in due course status to purchaser of negotiable instrument who "willfully failed to seek actual knowledge [regarding contract defenses of maker] because of a belief or a fear that an inquiry would disclose a failure of consideration for the note"). 
"holder in due course" (HDC).

- Sixth, any purchaser from an HDC is sheltered by the HDC's rights, unless that purchaser engaged in fraud or illegality affecting the instrument. ${ }^{60}$

- Seventh, the HDC or person whose rights derive from the holder in due course may enforce the instrument "free both of equities of prior owners of the instrument, and of defenses of the obligor except the so-called 'real' defenses." 61 The HDC is, in short, the "super-plaintiff."

Although Professor Gilmore offered this list in the early 1950s, it still more or less describes the strong form of negotiability contemplated by Article 3 . Article 3's strong negotiability has a variety of implications, the most important of which is that when the instrument is issued, the person to whom it is issued (usually the initial "holder"), obtains "title" to the instrument. The instrument itself, then, is a species of property which the holder can sell ("negotiate") to a purchaser, who would thereby become the holder. ${ }^{62}$

In addition to passage of title, negotiation confers a range of rights that we typically associate with doctrines of property, contract, and tort. ${ }^{63}$ Contract rights include the promise or order to pay money embodied in the instrument, as well as the several incidental undertakings that may surface in an instrument. ${ }^{64}$ Rights in tort include the right to sue a thief of the instrument for possession or in conversion. 65

The Article 3 model of negotiability is considered strong because of the rights it confers on the holder in due course, Article 3's version of the bona fide purchaser. The HDC of a negotiable instrument is one who takes an instrument for value, in good faith, without notice of a variety of somewhat unusual problems with the instrument. ${ }^{66}$ The HDC can enforce the instrument against most parties obligated, notwithstanding a variety of legitimate legal defenses (e.g.,

${ }^{60}$ Gilmore, supra note 53, at 1066 . Today, this rule-known as the "shelter rule"appears in U.C.C. section 3-203(b) (2001).

61 Gilmore, supra note 53, at 1066; see also U.C.C. § 3-305 (2001).

${ }^{62}$ See § 3-201 (2001) (“'Negotiation' means a transfer of possession ... to a person who thereby becomes its holder.").

${ }^{63}$ See id. §3-203(b) (2001) ("Transfer of an instrument ... vests in the transferee any right of the transferor to enforce the instrument.").

$64 \mathrm{Id}$. \$ 3-104(a)(3) (2001). These incidental, but permissible, undertakings include the granting of a security interest, a confession of judgment, or waivers of rights otherwise benefiting the obligor. $I d$.

${ }^{65}$ Id. $\S \S 3-306,-420$ (2001) (discussing possessory and conversion claims, respectively).

${ }^{66}$ Id. $\$ 3-301$ (a)(2) (2001). The problems are that the instrument contains an unauthorized signature, is subject to a property claim, or that anyone obligated on the instrument has a defense to payment. Id. 
the instrument had been stolen following indorsement in blank, or the contract for which the instrument was given was breached). ${ }^{67}$

HDC status is the ultimate form of bona fide purchase-"negotiability in excelsis," in the words of Professor Gilmore. ${ }^{68}$ Like the "market overt"-where goods could be sold free even of claims of theft ${ }^{69}$-the Article 3 negotiability model works on a bright line, giving the holder in due course the maximum bundle of rights assuming it satisfies the essential statutory elements of bona fide purchase.

Others have thoughtfully and thoroughly charted the rise of negotiability across species of property ${ }^{70}$ The analysis has focused principally on negotiable instruments, since these legal artifacts presented the earliest and most powerful challenges to ancient theories about property and contract. ${ }^{71}$ Here, the strong form of negotiability has generally enabled bona fide purchasers (HDCs) to enforce payment rights against a remote, prior party, notwithstanding most claims or defenses of that prior party. ${ }^{72}$ Although the continuing relevance of strong negotiability in the payments context is open to question, ${ }^{73}$ there remains pressure to permit the negotiability (broadly understood) of most commercial propertyincluding intangibles, such as information assets.

${ }^{67}$ Id. § 3-305(b) (2001).

${ }^{68}$ Grant Gilmore, Formalism and the Law of Negotiable Instruments, 13 CREIGHTON L. REv. 441, 461 (1979).

${ }^{69}$ See Robert H. Skilton, Buyer in Ordinary Course of Business Under Article 9 of the Uniform Commercial Code (and Related Matters), 1974 WIS. L. REv. 1, 33 (citing 30 HALSBURY, STATUTES OF ENGLAND 21 (3d ed. 1969)); see also Harold R. Weinberg, Markets Overt, Voidable Titles, and Feckless Agents: Judges and Efficiency in the Antebellum Doctrine of Good Faith Purchase, 56 TUL. L. REV. 1, 15-32 (1981). For example, French law provides: "If the present possessor of a thing stolen or lost bought it at a fair or at a market or at a public sale, or from a merchant selling similar things, the original owner may have it returned to him only by reimbursing the possessor for the price which it cost him." THE FRENCH CIVIL CODE art. 2280, at 419 (John Crabb trans., rev. ed. 1995).

${ }^{70}$ Morton J. HoRwitz, The Transformation of AMERICAN LAw, 1780-1860, at 212-26 (1977); Gilmore, supra note 68, at 441; Gilmore, supra note 53, at 1057; Menachem Mautner, "The Eternal Triangles of Law": Toward a Theory of Priorities in Conflicts Involving Remote Parties, 90 MiCh. L. REV. 95, 95 (1991).

71 See, e.g., HoRwIT, supra note 70, at 212 (negotiable instruments "challenged a whole range of accepted legal notions").

72 See § 3-305(a)-(b) (2001) (giving holders in due course right to enforce instrument notwithstanding claims or defenses of maker or drawer).

${ }^{73}$ See LOPUCKI ET AL., supra note 2, at 568-70 (questioning relevance of negotiability and holder in due course doctrine). 


\section{2. "Weak Negotiability"-General Intangibles}

General intangibles - the U.C.C. label that would cover most information assets $^{74}$-have met some obstacles in their seemingly inexorable march toward full negotiability. Initially, intangibles were not negotiable at all, for any of several reasons. Professor Gilmore suggested that reluctance to permit negotiation of intangibles may have reflected the fact that "our simple-minded ancestors were incapable of conceiving the transfer of rights in property that was not visible and tangible. 75 Others restricted the negotiation of intangibles on a privity of contract theory, ${ }^{76}$ or prohibited the assignment of intangibles as a function of public policy. ${ }^{77}$ For example, "Lord Coke remarked in Lampet's Case that if choses in action were assignable the result would be 'the occasion of multiplying contentions and suits, great oppression of the people, and chiefly terre-tenants, and the subversion of the due and equal execution of justice." 78

Nevertheless, Professor Gilmore observed that, consistent with the "steady progress in Anglo-American law toward complete alienability of rights," 79 general intangibles "have moved from being completely non-assignable, to being assignable in equity, to being assignable at law." 80 The kind of intangible that presented the greatest challenge to negotiability was the account receivable-the unpapered obligation owed by one person (the "account debtor") to a creditor for

$74 \S 9-102(a)(42)(2001)$.

751 GRANT GILMORE, SECURITY INTERESTS IN PERSONAL PROPERTY 200-01 (1965) (citing F.W. Maitland, The Mystery of Seisin, 2 L.Q. REV. 481 (1886)).

${ }^{76}$ Id. at 200-01 (citing AMES, THE INALIENABLITY OF CHOSES IN ACTION, LECTURES ON LEGAL HISTORY 210 (1913)). See generally 8 W.S. HOLDSWORTH, A HISTORY OF ENGLISH LAW 115 (1922); 2 SPENCE, THE EQUTTABLE JURISDICTION OF THE COURT OF CHANCERY 849 (n.p., 1850) (asserting "personal bond" theory); W.S. Holdsworth, The History of the Treatment of Choses in Action by the Common Law, 33 HARV. L. REV. 997 (1920)).

${ }^{77} 1$ GLLMORE, supra note 75, at 201 (citing Garrard Glenn, The Assignment of Choses in Action: Rights of Bona Fide Purchaser, 20 VA. L. REV. 621, 635 (1934)).

78 Id. (quoting Lampet's Case, 77 Eng. Rep. 994, 997 (1727)). Another, and doubtless correct, explanation is that "transactions in intangibles had never been of the slightest commercial importance." See Gilmore, supra note 1, at 612.

791 GLMORE, supra note 75, at 213.

${ }^{80}$ Id. Professor Gilmore observed that courts came to accept the alienability of intangibles by way of agency principles. The assignee of the contract right could sue in the name of the assignor, if the assignee held the "power of attorney." Id. at 201 (citing Holdsworth, supra note 76, at 1018-22). Gilmore explained this occurred because "[t]he social or economic utility of permitting creditors to transfer rights [was] believed to outweigh the utility of permitting obligors to forbid the transfer. That one utility outweighs the other lies beyond demonstration and proof." 1 GILMORE, supra note 75, at 212-13 (citing 1 MACLEOD, PRINCIPLES OF ECONOMIC PHILOSOPHY 481 (2d ed. 1872)). 
goods sold or services rendered.81 Although he acknowledged that "[n]othing less like a negotiable instrument can be imagined than an open account receivable," Professor Gilmore nevertheless observed that the U.C.C. as originally drafted sought to "give[] to commercial accounts [receivable] the free assignability which is a basic element of negotiability." 82

A critical issue in the negotiability of accounts receivable, then as now, was the effect of negotiation (transfer) on the equities, claims and defenses of the account debtor. The account debtor faced at least two problems. First, there was the problem of proof. It is easy to imagine that if the creditor (that is, the original obligee on the account) either sold or pledged his accounts receivable (including the account debtor's obligation), there was a chance that someone unknown to the account debtor would demand payment. Who was the account debtor supposed to pay - the original creditor, or some stranger purporting to have the rights of the original creditor? If the account debtor faced conflicting claimants, "he had to decide, at his peril, whom to pay." 83 Even if he paid in good faith, he remained liable to the rightful owner of the account. ${ }^{84}$

Second, there was the problem of defenses to payment. Unlike a statutory negotiable instrument, there could be no "holder in due course" of an account receivable. The only way to insure that the transferee of the receivable - whether an outright purchaser or a lender against the receivable-had the maximum power to enforce this intangible right was through the agreement that gave rise to the right in the first instance. Thus, the transferee of an account could obtain no better rights than those the transferor had. But nothing precluded the originator of the receivable from inserting terms in the contract that stripped the account debtor of equities, claims, and defenses against the assignee. This is known as "contractual" negotiability, a topic of modest historical interest. 85

Today, Article 9 attempts to maximize the negotiability of accounts receivable under section $9-406(d)$. This section essentially neutralizes any contract term, rule of law, statute or regulation that "prohibits, restricts, or requires the consent of the account debtor [to]" an assignment of an account, or the

81 Today, we define the account receivable as "a right to payment of a monetary obligation, whether or not earned by performance." See U.C.C. $\$ 9-102(a)(2)$ (2001). The definition of account excludes most other forms of payment obligation, including the negotiable instrument. See id.

82 Gilmore, supra note 53, at 1119 (citing U.C.C. \$ 9-318 (1972)).

83 Gilmore, supra note 68 , at 451 .

${ }^{84} \mathrm{Id}$.

85 See Gilmore, supra note 53, at 1089-93 ("We do not mean to cast doubt through anything written here upon the capacity of merchants to create new forms of negotiability by contract or by estoppel."') (quoting President \& Dirs. of Manhattan Co. v. Morgan, 150 N.E. 594, 598 (N.Y. 1926)). 
granting of a security interest in the account. ${ }^{86}$ This section does not, of course, strip the account debtor of claims or defenses, to the extent created by, or retained in, the agreement that gave rise to the receivable.

Perhaps the most important recent development is the statutory application of this model of negotiability to general intangibles, including information assets. Section 9-408(d) of the revision applies the section 9-406(d) model to general intangibles, permitting a transfer or the grant of a security interest notwithstanding a contractual or other legal restriction. I have suggested elsewhere that, if the equipment leasing model is any guide, then negotiability will be assured contractually, by the requirement that the licensee/account debtor agree to pay rent or other obligations "come hell or high water," thus insuring the liquidity of the contract notwithstanding claims and defenses. ${ }^{87}$ This kind of contractual negotiability may therefore be on the rise. ${ }^{88}$

As we shall see later, although Article 9 contemplates a kind of negotiability, in the sense that it permits certain dispositions free of a security interest, it also significantly restrains alienation in ways that will produce surprising and perhaps unjust results when information assets are collateral.

\section{B. Theories of Negotiability}

We tend today to assume the merits of free negotiability. This was not always so. Professor Gilmore, a principal architect of Article 9, opened one of his most famous articles by observing: "The triumph of the good faith purchaser has been one of the most dramatic episodes in our legal history."89 When Karl Llewellyn, the reporter for all of the U.C.C. and the principal drafter of Article 2 (sales of goods), was asked why the U.C.C. tended to prefer good faith purchasers over those with prior claims of ownership, he is reported to have replied: "The choice is hard, and it gives little satisfaction either way; but the Code's choice fits more comfortably into the whole body of our commercial law." 90

$86 \S 9-406(d)(1)$, -(f)(1) (2001) (discussing contract provisions and other provisions of law, respectively).

87 See Jonathan C. Lipson, Financing Information Technologies: Fairness and Function, 2001 WIS. L. REV. 1067, 1127-28.

${ }^{88} \mathrm{~A}$ kind of contractual negotiability also appears permissible under UCITA, as discussed in Part IV.B, infra.

${ }^{89}$ Gilmore, supra note 53, at 1057.

90 See William D. Warren, Cutting off Claims of Ownership Under the Uniform Commercial Code, 30 U. CHI. L. REV. 469, 493 (1963) (quoting 1 LAW REVISION COMM'N OF N.Y., HEARINGS ON THE UNIFORM COMMERCIAL CODE 59 (1954)); see also William H. Lawrence, The "Created by His Seller" Limitation of Section 9-307(1) of the U.C.C.: A Provision in Need of an Articulated Policy, 60 IND. L.J. 73, 88 (1984) ("[B]ona fide purchasers have become favorites of the law."). 
Although a complete consideration of the merits of negotiability is beyond the scope of this article, it would seem that negotiability has been justified on some combination of historical necessity and/or economic efficiency. Each may be seen to play a role in the growing negotiability of information assets.

The first famous pronouncement about negotiability did not bode well. In 1702, English Chief Justice Holt held that a promissory note sold by the payee, B, to $\mathrm{C}$ could not be enforced against the maker, $\mathrm{A} .{ }^{91} \mathrm{He}$ also notoriously observed that "[s]uch notes, were innovations upon the rules of the common law . . . and invented in Lombard Street, which attempted in these matters ... to give laws to Westminster Hall."92 Happy to follow Lombard Street's lead, Westminster Hall soon passed the Statute of $3 \& 4$ Anne, making promissory notes negotiable. ${ }^{93}$

Negotiability in the United States did not begin in earnest until the turn of the 19th century. As of 1800 , only five states had adopted the principle of negotiability. ${ }^{94}$ At least initially, negotiable paper solved problems posed by the scarcity of a stable currency. ${ }^{95}$ "In effect," Professor Gilmore observed, "the merchants and the bankers invented their own paper currency." 96 By the middle of the 19th century, however, currency reforms and a developing system of banking and finance rendered this explanation inaccurate. Nevertheless, the system of negotiability survived because the negotiable instruments rules that were developed in the prior 100 years "turned out to be exactly what a powerful group of entrepreneurs wanted in connection with novel types of transactions in

91 Clerke v. Martin, 92 Eng. Rep. 6, 2 Ld. Raym. 757 (1702).

92 Id. at 758. "Lombard Street" was a veiled reference to Jews, who were, for many years, essential to the enforcement of contractually assigned payment rights. Beginning in the twelfth century, Jews, whose law permitted the assignment of claims, also had a royal license to sue Christians in Jewish courts. "[П] a Christian took an assignment from a Jew . . [,]" Professor Gilmore has explained, "he would sue on the debt in the name of the Jewish assignor because 'by this method, the assignee obtained all the Jewish privileges of security, action and execution, which were not otherwise available to Christians." 1 GLMORE, supra note 75, at 202 (quoting S.J. Bailey, Assignment of Debts in England from the Twelfth to the Twentieth Century, 47 L.Q. REv. 516, 527 (1931)).

${ }^{93}$ HoRwITZ, supra note 70, at 214 (citations omitted).

94 Id. at 215.

95 Id. at 216 ("[T]he extreme scarcity of money thrust the problem of negotiability suddenly to the fore in the decade after the Peace of 1783."). Negotiability was sometimes attained by statute, sometimes by judicial fiat, and sometimes by law review article. The common law's embrace of negotiability - which rendered legislation unnecessary-appears to have been motivated in large measure by a famous essay by Circuit Judge William Cranch, published as an appendix to the case of Mandeville v. Riddle, 5 U.S. (1 Cranch) 290 (1803). Cranch's essay, 1 Cranch 367 (1803), challenged Lord Holt's view of the common law of negotiability and further argued that "equity" always recognized negotiability. See HoRWTZ, supra note 70 , at $221-22$.

96 See Gilmore, supra note 68 , at 447. 
which they were planning to engage . ...97 Negotiability, in other words, served the interests of a class of merchants and bankers for whom the unique attributes of its strong form proved lucrative.

Another explanation, rooted in theory if not fact, comes from the economists: Negotiability reflects unconscious judicial preferences for the efficient allocation of loss and risk. Writers associated with the law and economics school, for example, have argued that legal entitlements-such as the HDC's right to enforce an instrument despite defenses of the maker or drawer-are designed to minimize losses of competing claimants. ${ }^{98}$ Presumably, on this theory, the initial partiesthe maker (or drawer) and payee - can distribute (or prevent) the loss inter se more efficiently than could any later parties in the chain. Thus, the law generally tends to protect the later bona fide purchaser of the negotiated rights (the HDC), who does not (and often cannot) learn of underlying claims or defenses affecting the instrument. ${ }^{99}$

The efficiency rationale has a certain intuitive appeal, ${ }^{100}$ but has also been heavily criticized. ${ }^{101}$ It is beyond the scope of this article to assess fully the merits of the efficiency rationale. It is worth noting, however, that a more extreme version of the efficiency rationale - the rational choice model ${ }^{102}$ - seems to be losing force. On the rational choice view, we are (or are supposed to be) rational actors engaged in efforts to maximize our utility. The challenge for rational choice theory is simply that people may not be demonstrably rational, and often

${ }^{97}$ Id. at $451-52$.

98 See, e.g., RICHARD POSNER, ECONOMIC ANALYSIS OF THE LAW 84, 87-88, 106-07, 118, 121-22 (3d ed. 1986); see also Daniel A. Farber \& John H. Matheson, Beyond Promissory Estoppel: Contract Law and the "Invisible Handshake," 52 U. CH. L. REv. 903,906 n.12 (1985) (discussing "the emphasis in law and economics scholarship on the design of legal rules to affect behavior ex ante").

${ }^{99}$ See Mautner, supra note 70 , at 151 (discussing allocative efficiency of placing risk of loss with "owner" of goods in entrustment priority disputes).

100 "Economic analysis and criticism of judge-made law are in flower now in the academic groves-partly, I readily admit, because they are so often illuminating, clarifying, and stimulating, as well as elegant and captivating." Frank I. Michelman, Norms and Normativity in the Economic Theory of Law, 62 MINN. L. REv. 1015, 1027-28 (1978). "[S]triking successes [have been] achieved by the positive economic theory of law in showing a pervasive tendency for law-judicial, common law-to regress on a norm of pure efficiency." Id. at 1038.

101 See, e.g., J.M. Balkin, Too Good to be True: The Positive Economic Theory of Law, 87 Colum. L. Rev. 1447 (1987) (book review); Charles Fried, The Laws of Change: The Cunning of Reason in Moral and Legal History, 9 J. LEGAL STUD. 335 (1980); Michelman, supra note 100, at 1015; Wes Parsons, Note, The Inefficient Common Law, 92 YALE L.J. 862 (1983).

102 See Richard A. Posner, The Ethical and Political Basis of the Efficiency Norm in Common Law Adjudication, 8 HorSTRA L. REV. 487 (1980). 
do not "choose" in any meaningful way, certainly not one that can justify the occasionally harsh results of holder in due course doctrine. ${ }^{103}$

The law and economics movement is generally seen as having matured, and with it the rational choice view that the law has an objective measure by which to assess who amongst us is in the best position to absorb unanticipated losses. ${ }^{104}$ Many of the students of the law and economics school have offered a "new" twist on the rational choice model, the theory that "social norms" are in a reciprocal relationship with "the law." 105 The social norms school, which is often associated with the work of Robert Ellickson, ${ }^{106}$ but appears to have deeper, undisclosed roots in the works of Marx, Weber, and Durkheim, ${ }^{107}$ suggests that law incorporates rules that are not simply efficient, but instead emanate from collective preferences developed through complex methods of signaling and response.

The social norms school, also known as the "new Chicago School," has not yet offered a theory of negotiability or bona fide purchase, although it may do so one day. Certainly, in a larger sense, mercantile norms were heavily influential in the development of the architecture of negotiability in general, and the rights of the bona fide purchaser in particular. ${ }^{108}$ These norms may, of course, simply reflect the desire of elites to acquire (or justify) entitlements without worrying about later loss. This is hardly a new development, and has already been the subject of much thoughtful analysis. ${ }^{109}$

${ }^{103} \mathrm{~A}$ good recent discussion of the shortcomings of rational choice theory appears in W. Bradley Wendel, Mixed Signals: Rational-Choice Theories of Social Norms and the Pragmatics of Explanation, 77 IND. L.J. 1 (2002).

104 See, e.g., Symposium, The Future of Law and Economics: Looking Forward, $64 \mathrm{U}$. CHI. L. REV. 1129, 1129-224 (1997); Richard A. Epstein, Law and Economics: Its Glorious Past and Cloudy Future, 64 U. CHI. L. REv. 1167, 1167 (1997).

105 See, e.g., Symposium, Law, Economics, \& Norms, 144 U. PA. L. REV. 1643 (1996); Symposium, Law and Society \& Law and Economics: Common Ground, Irreconcilable Differences, New Directions, 1997 WIS. L. REv. 375; Symposium, The Legal Construction of Norms, 86 VA. L. REV. 1577 (2000); Symposium, Norms \& Corporate Law, 149 U. PA. L. REV. 1607 (2001); Symposium, Social Norms, Social Meaning, and the Economic Analysis of Law, 27 J. LeGAL STUD. 537 (1998). (1991)

106 Robert C. Ellickson, Order Without LaW: How Neighbors SetTle Disputes

107 Mark Tushnet, "Everything Old is New Again": Early Reflections on the "New Chicago School," 1998 WIS. L. REV. 579, 580.

108 See WILliam MitCHELl, ESSAY ON THE EARLy HiSTORY OF THE LAW MERCHANT 93102 (Burt Franklin 1969) (1904).

${ }^{109}$ See, e.g., G. Edward White, The Intellectual Origins of Torts in America, 86 YALE L.J. 671, 673 (1977) (arguing that modern tort doctrine arose to reflect the thinking of legal academic elite).

Normative support for strong negotiability may be found in Mautner, supra note 70, who argues that efficiency alone fails to justify strong negotiability. Rather, considerations of 
Whatever theory may explain negotiability, broadly understood it seems to be a robust attribute of commercial life. ${ }^{110}$ Indeed, to take an example from a slightly different context, the whole edifice of asset securitization-the sale of payment obligations into pools against which traded securities are issued-seems to be the great modern expression of the negotiability of payment rights. ${ }^{11}$ Securitization, like other forms of negotiability, purportedly reduces transaction costs and increases transaction volume by limiting purchaser risk. Like other forms of negotiability, the rights of prior claimants are neutralized or limited as against the purchaser of securities issued in an asset securitization. ${ }^{112}$

The question then becomes whether some aspects of the foregoing models and theories of negotiability can, or should, apply to information assets. As discussed in the next Part, the legal infrastructure that currently governs the generation and dissemination of information creates its own restraints on negotiability. These restraints, however, are justified and explained by different theoretical constructs, organized around the complex tension that seeks to promote the development of science and the arts.

retributive and distributive justice-claims that the bona fide purchaser has the greater moral right to priority-also support preferring the bona fide purchaser over the prior, wronged claimant (i.e., maker or drawer of the instrument). Id. at 149-52.

110 For a contrary view, in the context of investment securities, see James Steven Rogers, Negotiability, Property, and Identity, 12 CARDOZO L. REV. 471, 478 (1990) ("Evidence from various aspects of current commercial law suggests that in the twentieth century the general trend of development is away from negotiability."). See also Charles W. Mooney, Jr., Beyond Negotiability: A New Model for Transfer and Pledge of Interests in Securities Controlled by Intermediaries, 12 CARDOZO L. REV. 305 (1990); James Steven Rogers, Negotiability as a System of Title Recognition, 48 OHIO ST. L.J. 197 (1987).

111 See generally TAMAR Frankel, SECURTtZation: StructurEd FINANCING, Financial Asset PoOls, ANd Asset-Backed Securrties (1991 \& Supp. 1995); SECURTIZaTION OF FInANCIAL ASSETS (Jason H.P. Kravitt ed., 2d ed. 1997 \& Supp. 2000); Lois R. Lupica, Revised Article 9, Securitization Transactions and the Bankruptcy Dynamic, 9 AM. BANKR. INST. L. REV. 287, 288 (2001).

112 The goal of asset securitization is to limit the risk that the originator of the payment obligations - the initial creditor-will assert that it has retained an interest in these payment obligations after having purportedly sold them in the securitization. This risk was realized in $I n$ re LTV Steel Co., 274 B.R. 278 (Bankr. N.D. Ohio Feb. 5, 2001), where the bankruptcy court held that certain assets that the debtor sold in a purported "true sale" were, in fact, available to the debtor's estate for use in connection with a cash collateral order. The matter was later settled before an appeal was taken. See No. 00-43866, 2001 Bankr. LEXIS 635 (Bankr. N.D. Ohio Mar. 20, 2001); see also Jonathan C. Lipson, Enron, Asset Securitization and Bankruptcy Reform: Dead or Dormant?, 11 J. BANKR. L. \& PRAC. 101, 104 (2002). 


\section{RESTRAINTS ON NEGOTIABILITY}

Although information may be valuable, it may, like other forms of property, be subject to certain restraints on negotiation-not all information can be sold or licensed to all comers at all times. Indeed, the right to restrain others from developing or trafficking in information assets may be a critical source of their value. This Part summarizes certain non-Article 9 restraints that might affect the negotiability of information, in order to understand the backdrop against which Article 9 restraints function. Restraints on alienation-restrictions on negotiability-can occur under a wide range of laws. The most common nonArticle 9 sources of restriction outside the criminal context are those at property, contract, and under the government's general regulatory power.

\section{A. Property Rules}

The first and most important restraints on the negotiation of information are those that might arise under property doctrines. At the individual consumer level, property provides little protection from the exploitation and alienation of information about spending habits or genetic construction. At a commercial level, however, property rules seem to be heading toward a recognition that information has the attributes of commercial property (including the attribute of negotiability). That is, so far as property doctrine is concerned, individuals have little power to restrain others from creating, exploiting and negotiating-selling-information about themselves.

\section{Consumers}

There has been a robust discussion about whether the subjects of information-e.g., the consumers whose spending habits are captured on a database-have any property rights in information about themselves. Alan Westin first suggested that personal information was a species of property (belonging to the subject) more than thirty years ago. ${ }^{113}$ Notwithstanding the

113 See, e.g., ALAN F. WESTIN, PRIVACY AND FREEDOM 324-25 (1967) (“[P]ersonal information, thought of as the right of decision over one's private personality, should be defined as a property right, with all the restraints on interference by public or private authorities and due-process guarantees that our law of property has been so skillful in devising."); see also Jerry Kang, Information Privacy in Cyberspace Transactions, 50 STAN. L. REV. 1193, 1246-94 (1998) (suggesting privacy be treated in Cyberspace as a marketable commodity subject to default rules designed to permit an individual to impose limits on data reuse); Lawrence Lessig, The Architecture of Privacy, 1 VAND. J. ENT. L. \& PRAC. 56, 63-65 (1999) (suggesting market incentives as most effective means of privacy protection); Patricia Mell, Seeking Shade in a Land of Perpetual Sunlight: Privacy as Property in the Electronic Wilderness, 11 BERKELEY TECH. L.J. 1, 26-41 (1996); Arthur R. Miller, Personal Privacy in the Computer Age: The 
suggestion, there seems to be a steady erosion of property-based protection for the subjects of information, at least when the subjects are consumers. In the Toysmart.com case, for example, no public claim was made that the subjects of the debtor's database had a property right in the database such that they could restrain its sale. ${ }^{114}$ Thus, more recent thought has focused on restrictions at tort ${ }^{115}$ or contract, ${ }^{116}$ or simply by outright government regulation. 117

Consumer-level property rights appear to meet a similar fate in the bioinformation context. In Moore v. Regents of the University of California, 118 California's highest court held that the subject of cell line studies has no property interest in patents issued based on the subject's tissue samples. ${ }^{119}$ The decision

Challenge of a New Technology in an Information-Oriented Society, $67 \mathrm{MrCH}$. L. REV. 1091, 1223 (1969); Richard S. Murphy, Property Rights in Personal Information: An Economic Defense of Privacy, 84 GEO. L.J. 2381, 2384 (1996) ("The question the law must answer is: Who owns the property rights to such information . . . ?"); Carl Shapiro \& Hal R. Varian, U.S. Government Information Policy 45 (July 30, 1997) (paper presented to the Highlands Forum, Dept. of Defense, Washington, D.C.), available at http://www.sims.berkeley.edu/ hal/ Papers/policy.pdf.

114 Rather, as discussed below, the sale was restrained by the intercession of the Federal Trade Commission. See supra notes 199-205 and accompanying text.

115 Jessica Litman, Information Privacy/Information Property, 52 STAN. L. REV. 1283, 1312 (2000) ("An approach based loosely on the tort doctrine of breach of confidence might appeal to the courts.").

116 See, e.g., Steven A. Bibas, A Contractual Approach to Data Privacy, 17 HARv. J.L. \& PUB. POL'Y 591, 592 (1994) (claiming that a contractual solution most effectively protects privacy rights); Craig Martin, Mailing Lists, Mailboxes, and the Invasion of Privacy: Finding a Contractual Solution to a Transnational Problem, 35 Hous. L. REV. 801, 850 (1998) (proposing an "expansion of existing legislation, coupled with industry contracting"); Scott Shorr, Personal Information Contracts: How to Protect Privacy Without Violating the First Amendment, 80 CORNELL L. REV. 1756, 1759 (1995) (suggesting a property and contract law solution to protect privacy from credit bureau investigations). But see, e.g., Joel R. Reidenberg, Setting Standards for Fair Information Practice in the U.S. Private Sector, 80 IOWA L. REV. 497, 516-18 (1995).

117 See Litman, supra note 115, at 1302-03 (advocating a regulatory system in which personal data could not be owned as property).

118793 P.2d 479, 487-97 (Cal. 1990) (en banc). The claim that we have a property interest in our bodies has long historical roots, at least as far back as Locke, who argued that each of us holds "unquestionable property" over our own person and capacities and over "the Labour of [our] bod[ies]." JOHN LOCKE, THE SECOND TREATISE OF GOVERNMENT, 19 (C.B. Macpherson ed., Hackett Publ'g Co. 1980) (1690).

119 The plaintiff, John Moore, suffered from hairy cell leukemia, a rare disease that caused him to produce extraordinarily large quantities of lymphokines. Moore, 793 P.2d at 481 n.2. Moore's doctors, working with researchers at the University of Califomia, constructed a cell line using Moore's tissue with a commercial value estimated to be in the millions of dollars. Id. at 482. Not surprisingly, Moore believed that he had an interest in this jackpot and sued for 
has been controversial, 120 in part because we have no clear idea of the relationship between concepts of our bodies and concepts of property. Like the discourse about personal data, ${ }^{121}$ the analysis of biological material as property has focused on the relationship between privacy and property. Thus, some argue that the reason that we should have a property interest in our bodies is to protect privacy, ${ }^{122}$ while others argue that recognizing a property interest would produce the opposite result. ${ }^{123}$

In short, there is no apparent consensus on the role that property doctrine should play in protecting consumer-level rights in information. Rather, at this level, property seems an illusory source of protection.

\section{Commercial Usage}

That information-data or biological-is not "property" in the hands of the consumer-subject does not, however, end the property inquiry. Most thought about property rights in information is organized around doctrines known as "intellectual property." Intellectual property is shorthand for, among others, rights of copyright, patent, trademark, and trade-secret (or know-how). The first three

conversion, among other things, on the theory that the cell line was his "property." Id. at 480 83.

120 See, e.g., William Boulier, Note, Sperm, Spleens, and Other Valuables: The Need to Recognize Property Rights in Human Body Parts, 23 HOFSTRA L. REV. 693 (1995); Jennifer Lavoie, Note, Ownership of Human Tissue: Life After Moore v. Regents of the University of California, 75 VA. L. REV. 1363 (1989).

${ }^{121}$ Maureen A. O'Rourke, Fencing Cyberspace: Drawing Borders in a Virtual World, 82 Minn. L. Rev. 609 (1998); James Boyle, Shamans, Software, and Spleens (1996); Reichman \& Samuelson, supra note 22, at 51.

122 See Pamela Samuelson, A New Kind of Privacy? Regulating Uses of Personal Data in the Global Information Economy, 87 CAL. L. REV. 751, 771 (1999) (book review) [hereinafter, "Samuelson, A New Kind of Privacy?"] ("Propertizing personal information [would] . . g give members of the public some control, which they currently lack, over the traffic in personal data."). Professor Samuelson may have reconsidered this position. See Pamela Samuelson, Privacy as Intellectual Property?, 52 STAN. L. REv. 1125, 1171 (2000) [hereinafter, "Samuelson, Privacy"] ("If the goals and mechanisms of property law are misaligned with information privacy policy, objectives protecting privacy as intellectual property simply may not work.").

123 Moe M. Litman, The Legal Status of Genetic Material, in HUMAN DNA: LAW AND POLICY 17, 21 (Bartha Maria Knoppers ed., 1997) (recognizing property rights in human body might lead "to the erosion of the sanctity of human life, ... autonomy [and] privacy"). 
are govemed largely by federal law, ${ }^{124}$ while the last is a creature of state common or statutory law. 125

There has been a significant amount of discussion about the ebb and flow of the coverage of intellectual property rules. ${ }^{126}$ The current debate about information, and especially databases, is whether the existing intellectual property regime should be extended to cover data, or whether information is sui generis, and therefore requires a whole new approach. 127

\section{a. Trade Secret}

Although copyright and patent play important roles in the generation and protection of technologies involved with commercial transactions in information-they frequently capture rights in software and certain computer processes-they appear not to reach databases themselves. Rather, under Feist Publications, Inc. v. Rural Telephone Service Co., ${ }^{128}$ raw collections of facts-a functional list of telephone numbers, in that case-could not be considered a "work of authorship" for purposes of enjoying the exclusive rights conferred by the Copyright Act. Thus, if databases are to be protected at all, the protection would flow from the fairly weak rights conferred by the trade secret doctrine. ${ }^{129}$

124 See 17 U.S.C. $\$ \S 101-810$ (1994 \& Supp. 1998) (copyrights); 35 U.S.C. \$§ 1-376 (1994 \& Supp. 1998) (patents); 15 U.S.C. §§ 1051-1129 (1994 \& Supp. 1998) (trademarks).

125 Kewanee Oil Co. v. Bicron Corp., 416 U.S. 470 (1974) (applying Ohio trade secret law).

126 See Reichman \& Samuelson, supra note 22, at 64 ("“C]yclical fluctuations between states of under- and over-protection are a characteristic response to borderline subject matters that fit imperfectly within the classical patent and copyright paradigms.") (citations omitted).

127 See, e.g., Reichman \& Samuelson, supra note 22, at 65-66. The debate focuses principally on issues of market failures. Under-protection dilutes or eliminates incentives thought necessary to spur development, while over-protection leads to monopolies.

128499 U.S. 340, 363 (1991). Prior to Feist, there was support for the view that copyright could protect data on the theory that the information reflected the "sweat of the author's brow," even if the data was not especially creative. See, e.g., Leon v. Pacific Tel. \& Tel. Co., 91 F.2d 484, 486-87 (9th Cir. 1937) (protecting telephone listings). That said, some courts have been reluctant to take Feist too seriously, and hold that the low "creativity" threshold for copyright protection means that at least some databases should come within the scope of that body of law. See, e.g., CCC Info. Serv., Inc. v. Maclean Hunter Mkt. Reports, Inc., 44 F.3d 61, 65 (2d Cir. 1994).

129 See, e.g., Matthew Bender \& Co. v. West Publ'g Co., 158 F.3d 693 (2d Cir. 1998); CCC Info. Serv., 44 F.3d at 61; MAI Sys. Corp. v. Peak Computer, Inc., 991 F.2d 511, 519 (9th Cir. 1993) (affirming summary judgment finding trade secrets in plaintiff's customer database); BellSouth Adver. \& Publ'g Corp. v. Donnelley Info. Publ'g, Inc., 999 F.2d 1436, 1446 (11th Cir. 1993) (competing telephone directory publisher permitted to copy elements of compilation where selection, coordination, or arrangement of the data not copied); Victor Lalli Enter., Inc. v. 
A trade secret is "any formula, pattern, device, or compilation" with commercial value that is used in a business, is kept secret by the business, and provides that business with a competitive advantage over others who do not know or use the information. ${ }^{130} \mathrm{~A}$ trade secret is defined in the Uniform Trade Secrets Act as:

information, including a formula, pattern, compilation, program, device, method, technique or process, that: (i) derives independent economic value, actual or potential, from not being generally known to, and not being readily ascertainable by proper means by, other persons who can obtain economic value from its disclosure or use and (ii) is the subject of efforts that are reasonable under the circumstances to maintain its secrecy. ${ }^{131}$

Whether a firm has a trade secret depends upon, among other things,

(1) the existence or absence of an express agreement restricting disclosure, (2) the nature and extent of security precautions taken by the possessor to prevent acquisition of the information by unauthorized third parties, (3) the circumstances under which the information was disclosed ... to [any] employee to the extent that they give rise to a reasonable inference that further disclosure, without the consent of the possessor, is prohibited, and (4) the degree to which the information has been placed in the public domain or rendered 'readily ascertainable' by the third parties ... . 132

Trade secret has been used to protect pricing information, ${ }^{133}$ business methods and plans, ${ }^{134}$ marketing research data, ${ }^{135}$ and customer lists. ${ }^{136}$

Big Red Apple, Inc., 936 F.2d 671, 673 (2d Cir. 1991) (horse racing statistics compilation lacked sufficient selection and arrangement).

130 See RESTATEMENT OF TORTS $\$ 757 \mathrm{cmt} . \mathrm{b}$ (1934).

131 UNIF. TRADE SECRETS ACT § 1(4) (1979) [hereinafter UTSA]. The UTSA has been adopted in more than forty states. See UNIF. TRADE SECRETS ACT, 14 U.L.A. 182-83 (Supp. 2002).

132 USM Corp. v. Marson Fastener Corp., 393 N.E.2d 895, 900 (Mass. 1979) (quoting Kubic, Inc. v. Hull, 224 N.W.2d 80, 91 (Mich. Ct. App. 1974)).

133 See SI Handling Sys., Inc. v. Heisley, 753 F.2d 1244 (3d Cir. 1985).

134 See Clark v. Bunker, 453 F.2d 1006 (9th Cir. 1972).

135 See Western Electro-plating Co. v. Henness, 4 Cal. Rptr. 434, 436 (Cal. Ct. App. 1960).

136 See, e.g., Surgidev Corp. v. Eye Technology, Inc., 828 F.2d 452, 455-56 (8th Cir. 1987) (ophthalmologist customer list generally known to others in the industry entitled to trade secret status); Am. Paper \& Packaging Prods., Inc. v. Kirgan, 228 Cal. Rptr. 713, 716 (Cal. Ct. App. 1986) (citing 28 A.L.R. 3d 7 (customer list protected as trade secret)); Fred's Stores of Miss., Inc. v. M\&H Drugs, Inc., 725 So. 2d 902, 907 (Miss. 1998) (pharmacy master customer 
Merely having a list of facts, however, does not entitle the list to trade secret protection. The "exclusive" rights of trade secret are only as good as the secrecy of the information. This presents an obvious challenge to negotiability since the whole point of negotiating information is to sell or otherwise convey it to a third person. It is, as discussed below, possible to contract in such a way that transferees (purchasers) agree to preserve the secrecy of information and, one might imagine, trade secret protection for the information so conveyed. That said, at some point it would seem that wide scale commerce in trade secrets should cast doubt on the secrecy of the information in question. Agreeing that something is or should be a secret does not necessarily make it so.

Trade secret doctrine presents other problems as well. First, it is not clear that "trade secrets" are "property" at all. There are two main theories behind trade secret law, generally referred to as the "property school" and the "confidential relationship" school. ${ }^{137}$ Although courts have sometimes loosely referred to trade secrets as the "property" of the firm that licensed them, and have on occasion held trade secrets to be property for certain purposes, 138 "the more appropriate way to characterize the firm's interest in a trade secret is to say that the law protects the firm against breaches of contracts and confidential understandings,"139 "as well as against the use of improper means to obtain the secret."140 Professor Samuelson has argued that "trade secret law operates as a liability regime that discourages certain types of conduct rather than as an exclusive property right that may create a legal barrier to entry." 141

Second, and independent of the "is-it-property" question, restraints on alienation of trade secret are fairly weak. If, for example, a competitor independently develops the same or similar knowledge without resorting to industrial espionage, the originator of the information will have no cause of action. ${ }^{142}$ Even reverse-engineering - the intentional act of scraping secrets out of

list a trade secret where maintained confidentially); Town \& Country House \& Home Serv., Inc. v. Newbery, 147 N.E.2d 724, 725 (N.Y. 1958).

137 See JAMES PoOLEY, TRADE SECRETS $\$ 1.02(8)$ (1997).

138 See, e.g., Ruckelshaus v. Monsanto Co., 467 U.S. 986, 987 (1984) (finding trade secret information to be "property" within the meaning of the Fifth Amendment for purposes of deciding whether the government's unauthorized use or disclosure of the information should be subject to eminent domain rules).

139 Samuelson, Privacy as Intellectual Property?, supra note 122, at 1154-55 (citations omitted).

140 See id. at 1155 (citing E.I. duPont deNemours \& Co. v. Christopher, 431 F.2d 1012, 1015-16 (5th Cir. 1970)).

141 Reichman \& Samuelson, supra note 22, at 60-61.

142 See, e.g., Kewanee Oil Co. v. Bicron Corp., 416 U.S. 470, 487 (1974); UNIF. TRADE SECRETS ACT § 1(4), 14 U.L.A. 438 (1990). See generally J.H. Reichman, Overlapping Proprietary Rights in University-Generated Research Products: The Case of Computer 
a technology - is not an improper means of obtaining a trade secret. ${ }^{143}$ The prohibited revelation or sharing of a trade secret may expose the misbehaving party to damages, but those damages will likely be limited to the profits lost due to the wrongful acts, not due to the mere fact of discovery. ${ }^{144}$

\section{b. Copyright and Patent}

In short, the law of trade secret does not impose a significant restraint on the negotiability of information. But data are not the only information assets that might have commercial value, and trade secret is not the only source of legal protection. Software and other computer processes obviously play a central role in the creation and manipulation of information. And, unlike data, software is protected by both the Copyright Act and, perhaps, the Patent Act.

The Copyright Act and the Patent Act are intended to "promote the Progress of Science and useful Arts" by granting to authors exclusive rights over their copyrighted works for a limited time, as an incentive to the creation and dissemination of such works. ${ }^{145}$ Under the Copyright Act, authors and owners of copyrights immediately possess the exclusive rights to reproduce, distribute, perform, and display copyrighted works and to prepare derivative works based on them. ${ }^{146}$ Patents are granted to inventors as monopolies of the right to make, use, and sell their inventions for a limited term. ${ }^{147}$

Programs, 17 COLUM.-VLA J.L. \& ARTS 51, 93-98 (1992); RESTATEMENT (THIRD) OF UNFAIR COMPETITION $\$ \S 39-45$ (1995) (restating the norms of trade secrecy law).

143 RESTATEMENT (THIRD) OF UNFAIR COMPETTION $\$$ 39-45 (1995).

144 Id. $\$ 35$. A recent example appears in Sony Computer Entertainment, Inc. $v$. Connectix Corp., 203 F.3d 596, 599 (9th Cir. 2000) (holding that copyright fair use doctrine permitted reverse engineering).

145 See Harper \& Row Publishers, Inc. v. Nation Enter., 471 U.S. 539, 558 (1985) ("[C]opyright supplies the economic incentive to create and disseminate ideas."); Sony Corp. of Am. v. Universal City Studios, Inc., 464 U.S. 417, 429 (1984) (explaining that copyright is "intended to motivate the creative activity of authors ... and to allow the public access to the products of their genius after the limited period of exclusive control has expired").

146 Section 106 of the Copyright Act provides:

Subject to sections 107 through 121, the owner of a copyright under this title has the exclusive rights to do and to authorize any of the following:

(1) to reproduce the copyrighted work in copies or phonorecords;

(2) to prepare derivative works based upon the copyrighted work;

(3) to distribute copies or phonorecords of the copyrighted work to the public by sale or other transfer of ownership, or by rental, lease, or lending;

(4) in the case of literary, musical, dramatic, and choreographic works, pantomimes, and motion pictures and other audiovisual works, to perform the copyrighted work publicly; and 
In the case of both copyright and patent, negotiability of the protected information is constrained because title is so absolutely defined and readily restricted. The exclusive rights of patent and copyright focus principally on title, and exclusion of use of the protected invention or work. Thus, the principal cause of action a title (or other rights) holder would bring under either law would be an infringement action, a kind of ejectment. ${ }^{148}$

Copyright is critical to the protection of software and related computer processes. As one author explains "for purposes of the copyright statute, every [computer] code format in which a program may exist is a 'copy' of the other."149 Thus, the Final Report of the National Commission on New Technological Uses of Copyright Works (the CONTU Report) ${ }^{150}$ recognized that simply loading a program onto a magnetic disk or into a computer's semiconductor memory, is copying for purposes of the Copyright Act, ${ }^{151}$ and courts apparently agree. ${ }^{152}$

(5) in the case of literary, musical, dramatic, and choreographic works, pantomimes, and pictorial, graphic, or sculptural works, including the individual images of a motion picture or other audiovisual work, to display the copyrighted work publicly.

17 U.S.C. $\S 106$ (2000).

147 Section 154 of the Patent Act provides:

Every patent shall contain a . . grant to the patentee, his heirs or assigns of the right to exclude others from making, using, offering for sale, or selling the invention throughout the United States or importing the invention into the United States, and, if the invention is a process, of the right to exclude others from using, offering for sale or selling throughout the United States, or importing into the United States, products made by that process ....

35 U.S.C. $\$ 154(a)(1)(2000)$.

148 See, e.g., Strait v. Nat'l Harrow Co., 51 F. 819, 820-21 (C.C.N.D.N.Y. 1892) (patent). See generally Ticketmaster Corp. v. Tickets.com, Inc., 54 U.S.P.Q.2d (BNA) 1344 (C.D. Cal. 2000), injunction denied, No. CV 99-7654, 2000 WL 1887522 (C.D. Cal. Aug. 10, 2000), aff d, 2 Fed. Appx. 741 (9th Cir. 2001); Ebay, Inc. v. Bidder's Edge, Inc., 100 F. Supp. 2d 1058, 1073 (N.D. Cal. 2000) (enjoining Bidder's Edge from using automated querying programs to access Ebay's on-line auction site on trespass theory); 6 DONALD S. CHISUM, CHISUM ON PATENTS $\S 19.04(1)(a)(2001)$.

149 MiChaEl A. EPSTEIN, EPSTEIN ON INTELlectual PROPERTY $\S 10.01(\mathrm{~A})(4)(\mathrm{c})$, at 10 15 (4th ed. 2000).

150 In 1974, the National Commission on New Technological Uses of Copyright Works was established by Congress.

151 CONTU's FINAL RePORT AND ReCOMmENDATIONS 13-14 (Nicholas Henry ed., 1980).

152 See, e.g., Triad Sys. Corp. v. Southeastem Express Co., 64 F.3d 1330, 1335 (9th Cir. 1995); MAI Sys. Corp. v. Peak Computer, Inc., 991 F.2d 511, 517 (9th Cir. 1993); Religious Tech. Ctr. v. Netcom On-Line Communication Servs., Inc., 907 F. Supp. 1361, $1366-67$ (N.D. Cal. 1995); Advanced Computer Servs. of Mich., Inc. v. MAI Sys. Corp., 845 F. Supp. 356, 
Therefore, one potentially infringes copyright by copying from a magnetic medium such as a diskette to a chip, ${ }^{153}$ from one hard drive to another, ${ }^{154}$ or, in theory, simply by loading a webpage onto a computer.

Patent may be giving copyright a run for its money in this regard. Until recently, patent protection was not generally considered to be available to software because software was viewed as a "mathematical algorithm"-a mere thought process - and therefore not capable of patent protection. ${ }^{155}$ In 1998, however, the Federal Circuit opened the door to patent protection for computerrelated inventions in State Street Bank \& Trust Co. v. Signature Financial Group, Inc. ${ }^{156}$ There, the court held that a data processing system for implementing an investment structure could be subject to patent protection for a "machine" invention. ${ }^{157}$ The mathematical nature of the claim was no impediment to patent protection. "[T]o be patentable," the court reasoned, "an algorithm must be applied in a 'useful' way."158 Thus, the Federal Circuit announced that the proper standard for statutorily patentable subject matter is whether the claim produces "a useful, concrete and tangible result"- that is, practical utility. ${ }^{159}$

More recently, in AT\&T Corp. v. Excel Communications, Inc., the Federal Circuit extended the State Street utility standard to "methods." 160 Similarly, the Federal Circuit recently viewed Amazon.com's "one-click" method and system for placing a purchase order over the Intemet as patentable subject matter. ${ }^{161}$ "Business method" patents, such as those upheld in State Street and Excel, will

362 (E.D. Va. 1994); cf. Lewis Galoob Toys, Inc. v. Nintendo of Am., Inc., 964 F.2d 965, 969 (9th Cir. 1992) (holding that a device that altered images without altering program did not create a sufficiently fixed, derivative work).

153 Peak Computer, 991 F.2d at 519.

154 See Atari Games Corp. v. Nintendo of Am., Inc., 975 F.2d 832, 837 (Fed. Cir. 1992).

155 See Diamond v. Diehr, 450 U.S. 175, 182 (1981); Diamond v. Chakrabarty, 447 U.S. 303, 309 (1980).

156149 F.3d 1368 (Fed. Cir. 1998). Prior to 1998, something known as the FreemanWalter-Abele test was used to determine whether a mathematical algorithm was an unpatentable abstract idea. The two-part test was developed by the Court of Customs and Patent Appeals and later adopted by the Federal Circuit. Id. at 1374 ("After Diehr and Chakrabarty, the Freeman-Walter-Abele test has little, if any, applicability to determining the presence of statutory subject matter.").

157 See id. at 1370 (explaining that the program was "directed to a data processing system ... for implementing an investment structure which was developed for use in [patent holder]'s business as an administrator and accounting agent for mutual funds").

158 Id. at 1373.

${ }^{159}$ Id.

160172 F.3d 1352, 1358 (Fed. Cir. 1999).

161 Amazon.com, Inc. v. Barnesandnoble.com, Inc., 239 F.3d 1343, 1366 (Fed. Cir. 2001) (finding that although patent holder showed likely infringement, patent may be invalid based on obviousness of prior art and remanding to district court). 
likely expand the class of patentable inventions to include software and many information technology-related business methods. ${ }^{162}$

Patent is also the principal vehicle for protecting bioinformation assets. Until 1980 , it was not clear that patent was available to protect biological inventions. That year, the Supreme Court decided Diamond v. Chakrabarty, ${ }^{163}$ which recognized an inventor's right to patent a genetically engineered bacterium capable of breaking down crude oil. The patentability of life forms, and in particular stem cell lines, has led to no small amount of anxiety about the morality and economics of controlling this bundle of rights. 164 "An economy of ideas that is not tempered by a sense of civic-minded purpose is a disaster waiting to happen," one author recently lamented. 165

As noted above, it would appear that the individual who is the source of the biological material-the donor of the stem cells, for example-has no property interest in a patent granted to an inventor who developed the cell line. ${ }^{166}$ Thus, the individual source of the biological material cannot restrain the negotiation of his biological material on a property theory. The holder of the patent, by contrast, can restrain negotiation in the sense that the patent holder has a monopoly on the use of the patented invention. The right to restrain alienation of basic scientific knowledge has been characterized as an enormous threat to the development of

162 Some think the State Street decision will result in an increase in the number of patent applications. See Robert M. Kunstadt, Sneak Attack on U.S. Inventiveness, NAT'L. L.J., Nov. 9, 1998, at A21; W. Scott Petty, InternetInfo.column: State Street Bank Fuels Boom in Business Model Patents, INTELL. PROP. TODAY, Apr. 1999, at 30. Others are more cautious in their assessment. See, e.g., Francis Marius Keeley-Domokos, State Street Bank \& Trust Co. v. Signature Financial Group, Inc., 14 BERKELEY TECH. L.J. 153, 171 (1999); Thomas S. Hahn, No 'State Street' Revolution Coming, NAT'L. L.J., Dec. 7, 1998, at A21.

In July 2000, the U.S. Patent Office issued a USPTO White Paper announcing its plans to improve the quality of the examination process in electronic commerce and business method technologies. U.S. PATENT \& TRADEMARK OfFICE, USPTO WhITE PAPER: AUTOMATED FinanCIal OR MANAGEMENT Data PROCESSING METHODS (Business METHODS) (July 2000), available at http://www.uspto.gov/web/menu/busmethp/index.html (last visited Nov. 8, 2002).

163447 U.S. 303, 309, 318 (1980).

164 Among others, there are concerns about creating monsters, see Thomas A. Magnani, Biotechnology and Medical Devices: Patenting Lifeforms: Chimeras: The Patentability of Human Animal Chimeras, 14 BERKELEY TECH. L.J. 443 (1999) (describing the nature of chimera inventions, and the legal, moral, and policy concerns raised by such patents), about the possibility that a few corporations will control the seeds from which staple crops are grown, Paul M. Barrett, High-Court Battle Sprouts from Clash between Farmers and the Seed Industry, WALL ST. J. May 23, 1994, at B1, and that proprietary claims will be asserted over life-saving medical techniques, Sally Squires, AMA Condemns Patents for Medical Procedures, WASH. POST, June 20, 1995, at A1.

165 SETH SHULMAN, OWNING THE FUTURE 12 (1999).

166 See discussion at notes 118-19, supra. 
science and technology. ${ }^{167}$ Yet, there seems to be widespread recognition that the exclusive rights granted by the Patent Act provide an important incentive for innovation. The dispute is not usually about the fact of restraint, but the scope of coverage.

The relationship between intellectual property protection and negotiability is not well understood. One can imagine that the comparative strengths and weaknesses of any particular intellectual property regime may have important, yet indeterminate, effects on the negotiability of the underlying property. The weakness of trade secret protection might, for example, imply weak rights of negotiability because, as a practical matter, dissemination of information will often destroy its secrecy. Negotiation on a large scale would dilute the value of the information.

However, weak trade secret protection might instead suggest more negotiation (i.e., transactions), because the very weakness of protection would restrain few transactions. $\mathrm{B} / \mathrm{L}^{2}$ could, for example, effectively be a bona fide purchaser of information that was protected solely by trade secret doctrine even where D, as the true "owner," had never consented to the transfer.

A similar duality may be imagined in the context of the copyright and patent rules. The strong, "exclusive" rights assured by these rules might diminish negotiability because there could be no "bona fide purchasers" of these assets absent the consent of the true "owner" (or authorized licensor). On the other hand, if strong property protection encourages invention and creation, it may be that copyright and patent will, in fact, result in increased negotiation of information assets protected by copyright and patent rules. ${ }^{168}$

167 See, e.g., BoYLE, supra note 121 , at 41-42.

168 Copyright and patent (but not trade secret) also present another, tangential problem: federal preemption. Because the Copyright Act and the Patent Act are both federal law, they will preempt conflicting state law (such as the U.C.C.). Federal preemption doctrine in this context is confused, to say the least. See Lipson, supra note 87, at 1104-17 (discussing instability of federal preemption doctrine). Until recently, the general view was that the Copyright Act largely (perhaps wholly) preempted state law governing the transfer of copyrights, while the Patent Act did not. Compare In re Peregrine Entm't, Ltd., 116 B.R. 194 (Bankr. C.D. Cal. 1990) (Copyright Act), with In re Cybernetic Servs., 252 F.3d 1039 (9th Cir. 2001) (Patent Act). See also Lipson, supra note 87, at 1071 (observing that "varying rules" on federal preemption "defy a principled explanation"). More recently, the Ninth Circuit Court of Appeals may have taken a step toward minimizing the confusion in its opinion in In re World Auxiliary Power Co., 303 F.3d 1120, (9th Cir. 2002). There, the court appears to have limited the Peregrine rule to cases where the copyright was actually registered with the Copyright Office. Id. at 1128 . (" $[\mathrm{U}]$ nregistered copyrights don't have to be registered, and because unregistered copyrights don't have a registered name and number, under the Copyright Act there isn't anyplace to file anything regarding unregistered copyrights that makes any legal difference."). 


\section{B. Contract Rules}

There will, of course, always be a solution to the problem of property-based restraints on negotiability: contract, which can usually provide as much or as little negotiability as the contracting parties want. The principal contractual vehicle for the negotiation of information appears to be the license. A license is simply permission to use an asset subject to certain contractual restrictions. ${ }^{169}$ Most licenses are not exclusive in the sense that they do not convey title to the subject property. ${ }^{170}$ Even though title does not necessarily pass, licensing is a form of negotiation in the sense that it can result in the conveyance of rights from (or about) $\mathrm{A}$ to $\mathrm{B}$ to $\mathrm{C}$. The bundle of rights embodied in the license can, however, carry important restraints on further negotiation by the licensee. ${ }^{171}$

The most famous (or infamous) example of restraint via license appeared in the controversial case ProCD, Inc. v. Zeidenberg, ${ }^{172}$ where the Seventh Circuit Court of Appeals concluded that a "shrinkwrap" license was binding on the purchaser of a CD-ROM, even though the terms could not be seen until after the disk was purchased. ${ }^{173}$ The license term in dispute was a restriction on the use of the information (a database of telephone numbers) contained on the CD-ROM for "non-commercial purposes."174 Zeidenberg, the purchaser, refused to respect the restriction, and used the CD-ROM to generate his own, virtually identical CDROM, which he then sold at a much lower price than did the original seller, ProCD. ProCD sued to enjoin the sales and Judge Easterbrook, writing for the Court of Appeals for the Seventh Circuit, thought ProCD had the better argument for one simple reason: The "contract" (the license) was binding on Zeidenberg. 175

169 ThOMAS M. WARD, INTELLECTUAL PROPERTY IN COMMERCE \$ 2.29, at 2-83 ("“A] license is usually just a contractual promise of immunity from an infringement suit.").

170 Another kind of "exclusive" license is the agreement by the licensor not to license the subject property to anyone else, at least for a limited period of time. Licensing in this context appears to have developed as a protection against, among other things, the "first sale" doctrine under copyright law. Under the first sale doctrine, appearing at 17 U.S.C. $\$ 109$ (a), once the copyright holder has sold a copy of a work, the holder loses control over subsequent distributions of that particular copy of the work. See Quality King v. L'Anza, 523 U.S. 135 (1998) (applying copyright first sale doctrine to imported goods which had copyrighted labels); Bobbs-Merrill Co. v. Straus, 210 U.S. 339, 342 (1908). A similar rule exists under patent law.

171 See Boss, supra note 20, at 182 ("'A] license agreement allows the producer or developer of 'virtual goods' (or services) to exercise control over the product down through the licensing chain.") (quoting Legal Aspects of Electronic Commerce: Possible Future Work in the Field of Electronic Contracting: An Analysis of the United Nations Convention on Contracts for the International Sale of Goods, I 28, U.N. Doc. A/CN.9/WG/IV/WP.91 (Feb. 9, 2001).

172 86 F.3d 1447 (7th Cir. 1996).

173 Id. at 1451.

174 Id. at 1450 .

175 Id. 
ProCD has been controversial for a number of reasons. The principal questions about the case ask whether contracts should be so adhesive, and whether (or to what extent) its holding impermissibly intrudes on federal copyright law. ${ }^{176}$ Whether ProCD stands the test of time, it would appear that there is some movement toward creating a uniform set of rules that would govern licensing and similar computer information transactions. Licensing has an important history in making information a negotiable commodity. Initially, the license was the contract whereby the developer and owner of software would permit the end-user to use the software. ${ }^{177}$ Software is, of course, critical to the technologies that generate, manipulate, and distribute information. Licensing has moved from being mere permission to use software to become an important contractual form governing the use of many information assets. ProCD is simply a strong expression of the contractual powers of licensors.

An even stronger expression appears in the Uniform Computer Information Transactions Act (UCITA). ${ }^{178}$ UCITA purports to create a kind of "mini-U.C.C." for transactions involving computer information (e.g., software licenses and data transfers). UCITA would, like Article 2 of the U.C.C., create a series of default rules for "computer information transactions." 179 Although licensing transactions were the genesis of UCITA, the statute would effectively cover any "agreement or the performance of it to create, modify, transfer, or license computer

176 See, e.g., Charles R. McManis, The Privatization (or "Shrink-Wrapping") of American Copyright Law, 87 CAL. L. REv. 173, 178-79, 182-84 (1999). While one can reasonably debate the merits of $P r o C D$ 's approach to contract, its statutory construction leaves something to be desired. A central ground offered for enforcing the license, Judge Easterbrook reasoned, came from the various provisions of Article 2 of the U.C.C. See ProCD, 86 F.3d at 1452-53. He does not, however, explain why Article 2 should apply at all. By its terms, Article 2 governs sales of goods. A CD-ROM-a collection of digitized facts-should probably be characterized under the U.C.C. as "general intangibles." Indeed, in July 2002, the American Law Institute (a principal sponsor of the U.C.C.) approved an amendment to Article 2 that would exclude "information" from the definition of goods. See New Prefatory Note and Language on Scope of UCC Article 2 Amendments Approved by NCCUSL, http://www.ali.org/ali/pr081402NCCUSL.htm (last visited Nov. 8, 2002) ("The definition of 'goods' has been amended to exclude information not associated with goods.").

177 See Pamela Samuelson \& Kurt Opsahl, How Tensions Between Intellectual Property Policy and UCITA are Likely to be Resolved, 570 PLI/PAT 741, 746 (1999); see also David A. Rice, Digital Information as Property and Product: U.C.C. Article 2B, 22 U. DAYTON L. REV. 621, 623-27 (1997); J. Thomas Warlick, IV, A Wolf in Sheep's Clothing? Information Licensing and De Facto Copyright Legislation in UCC 2B, 45 J. COPYRIGHT SOC'Y U.S.A. 158, 159-61 (1997).

178 Nat'l CONFERENCE OF COMm'rs. ON UNIF. STATE LaWs, UNIFORM COMPUTER INFORMATION TRANSACTIONS ACT (2002), available at http://www.law.upenn.edu/bll/ulc/ucita/ ucitaFinal00.pdf [hereinafter UCITA].

${ }^{179}$ Id. \& 103(a). 
information." 180 "Computer information" is defined as "information in electronic form which is obtained from or through the use of a computer or which is in a form capable of being processed by a computer."181 "Informational rights" are "all rights in information created under laws governing patents, copyrights, mask works, trade secrets, trademarks, publicity rights, or any other law that gives a person, independently of contract, a right to control or preclude another person's use or access to the information on the basis of the rights holder's interest in the information." 182

Among other things, UCITA would establish (i) default rules on contract (i.e., license) formation, ${ }^{183}$ (ii) limitations on licensor warranties, ${ }^{184}$ (iii) the power to change license terms after formation, ${ }^{185}$ and (iv) licensor self-help rights to terminate licensee usage. ${ }^{186}$ Perhaps most attention has focused on UCITA's attempt to validate mass-market licenses. Mass-market transactions are defined as those that are "directed to the general public as a whole," under substantially the same terms for the same information. The definition includes all consumer transactions, and business transactions in which the licensee acquires the rights in a retail transaction. ${ }^{187}$

The key to the mass-market transaction is the absence of bargaining: Like ProCD, UCITA would sanction "pay now, terms later" contracts. ${ }^{188}$ Under UCITA, a binding contract will be formed in a mass-market transaction where the end user "manifests assent" to the contract. Assent may be made manifest without "a signature, specific language or any specific conduct."189 Professor Samuelson has explained that this concept "embraces the notion that opening a shrinkwrap

180 Id. $\$ 102(\mathrm{a})(11)$.

181 Id. $\$ 102(\mathrm{a})(10)$.

182 Id. \& 102(a)(38).

183 Id. $\$ 209$. UCITA provides that a licensee may be bound by a license before having had the opportunity to review it. See Brian D. McDonald, The Uniform Computer Information Transactions Act, 16 BERKELEY TECH. L.J. 461, 464 (2001).

184 See UCITA, supra note 178, §406; Mary Jo Howard Dively, Uniform Computer Information Transactions Act: Warranties, Disclaimers, and Remedies, 600 PLI/PAT 491, 493 (2000).

185 See UCITA, supra note $178, \S 304(\mathrm{~b})$.

186 See id. \$\$ 815-16; McDonald, supra note 183, at 465; Timothy P. Heaton, Note, Electronic Self-Help Software Repossession: A Proposal to Protect Small Software Development Companies, 6 B.U. J. SCI. \& TECH. L. 8 (2000); Robbin Rahman, Comment, Electronic Self-Help Repossession and You: A Computer Software Vendor's Guide to Staying Out of Jail, 48 EMORY L.J. 1477 (1999).

187 UCITA, supra note 178, § 102(a)(45).

188 Maureen A. O'Rourke, Progressing Towards a Uniform Commercial Code for Electronic Commerce or Racing Towards Nonuniformity?, 14 BERKELEY TECH. L.J. 635, 651 (1999).

189 UCITA, supra note 178 , reporters note to $\S 102$. 
covering, or clicking on an electronic button is enough agreement to satisfy the law."190 While relevant to all transactions within UCITA's scope, the concept plays a critical role in validating terms contained in mass-market transactions. It would make ProCD the uniform law of the land.

UCITA itself says little about the negotiability of information. Rather, it would validate most contractual provisions that either permit or restrict the negotiation of information within UCITA's scope. Thus, if it becomes widely accepted, UCITA will likely be central to other aspects in the effort to make information a negotiable commodity. It will, for example, likely be the case that part of the clickwrap contract includes a waiver of privacy rights in information given to the vendor by the end-user/purchaser. UCITA would appear to validate such provisions. UCITA may also validate waivers of warranties of title, merchantability, etc. ${ }^{191}$ Such waivers could function like "hell or high water" equipment leases, in which the licensee would be bound to pay no matter the defaults of the licensor or defects in the licensed information. ${ }^{192}$

One defect of note might be the prior encumbrance of the licensed information, either by the licensor or some prior party in the chain of production. A licensee that waived this defect would, in the eyes of UCITA (and perhaps the ProCD court), apparently have agreed to purchase/license information assets-a CD-ROM with phone numbers; a customer list-subject to an Article 9 security interest of which it was not (and perhaps could not have been) aware. Having waived in the license its right to refuse payment for any reason, it would-like the account debtor of old-face the unhappy prospect of having to pay for the license twice: once to the licensor, and again to the secured party (perhaps legitimately) claiming an interest in the licensed information.

Notice that in this respect UCITA and ProCD would tolerate a kind of contractual negotiability akin to that represented by U.C.C. Article 3's strong model. ${ }^{193}$ Like the HDC of a negotiable instrument, the licensor of information

190 Samuelson, A New Kind of Privacy?, supra note 122, at 754.

${ }^{191}$ In a transaction involving the sale of goods, under U.C.C. section 2-312 the seller warrants that it sells goods free of security interests. Similar warranties are made with respect to transactions in negotiable instruments. See U.C.C. $\$ \$ 3-416,-417$ (2001). UCITA, by contrast, contains no comparable warranty of title. Under UCITA section 401(a), a licensor of information "warrants that the information will be delivered free of the rightful claim of any third person by way of infringement or misappropriation." UCITA, supra note $178, \S 401$ (a). This would appear to mean that a licensee or purchaser of information under UCITA takes the risk that it acquires informational rights subject to an undisclosed security interest. Alternatively, a licensee may well agree to pay its license fees "come hell or high water," as has often been the case under equipment leases. UCITA's self-help provisions would seem to enable the secured party of the licensor that enforces a security interest in the license to effectively disable the end-user's computer. See Lipson, supra note 87, at 1127-28.

192 See Lipson, supra note 87, at 1127.

193 See discussion of models of negotiability in Part III.A, supra. 
assets would have the right to enforce the license terms against the licensee notwithstanding contractual claims or defenses (e.g., the licensed product did not work; the information was previously encumbered). UCITA would validate such provisions even though they may contradict other laws or public policy. Unlike the strong negotiability of Article 3, for example, UCITA would appear to create no "real" defenses that would supercede contract and be effective against even a bona fide purchaser.

This unilateral power would enable licensors (or others who write contracts governed by UCITA) to create, in the words of J.H. Reichman and Jonathan Franklin, "private legislation that is valid against the world."194 UCITA would function as a kind of one-way ratchet, enabling licensors to lever terms and conditions into contracts that are binding on end-users while apparently eliminating their own culpability in the event the information they sell or license proves to be defective or subject to a prior encumbrance.

The future of UCITA is unclear. Although the National Conference of Commissioners on Uniform State Laws (NCCUSL) drafted, adopted and recommended UCITA to all fifty legislatures, ${ }^{195}$ only two states-Maryland and Virginia-have enacted anything resembling it. ${ }^{196}$ Significant political problems with the statute have emerged, organized chiefly around the power UCITA gives software makers as against consumers. ${ }^{197}$ Nevertheless, the "freedom of contract" ethos embodied in UCITA (and cases like ProC ${ }^{198}$ ) may reflect a deeper undercurrent which could lead to widespread enactment of UCITA or something like it.

194 J.H. Reichman \& Jonathan A. Franklin, Privately Legislated Intellectual Property Rights: Reconciling Freedom of Contract with Public Good Uses of Information, 157 U. PENN. L. REv. 875, 911 (1999).

195 Unif. Law Comm'rs., Introductions \& Adoptions of Uniform Acts: A Few Facts About the Uniform Computer Information Transactions Act, http://www.nccusl.org/nccusl/ uniformact_factsheets/uniformacts-fs-ucita.asp (last visited Oct. 26, 2002).

196 Virginia enacted the UCITA on March 14, 2000. Uniform Computer Transactions Act, S.B. 372, 2000 Va. Acts ch. 43 (2000). Maryland enacted a somewhat diluted version on April 10, 2000, which it renamed the "Maryland Computer Information Transactions Act." Maryland Uniform Computer Information Transactions Act, H.D. 19, 2000 Md. Laws 11.

197 Iowa, West Virginia and North Carolina have adopted so-called "bomb-shelter" provisions that would expressly disable the use of UCITA in those states via choice of law or similar clauses. See Uniform Electronic Transactions Act, IOWA CODE ANN. § 554D (West Supp. 2001), 2000 Iowa Legis. Serv. H.D. 2205 (West) ("A choice of law provision . . . which provides that the contract is to be interpreted pursuant to the laws of a state that has enacted the Uniform Computer Information Transactions Act . . . or any substantially similar law, is voidable."); Uniform Electronic Transactions Act, W. VA. CODE ANN. \$ 55-8-15 (Mitchie Supp. 2001); 2001 N.C. Sess. Laws 2001-295 § 66-329; see also McDonald, supra note 183, at 468-70 (discussing "bomb-shelter" provisions).

198 See also Hill v. Gateway 2000, Inc., 105 F.3d 1147 (7th Cir. 1997). 


\section{Regulatory Restraints}

In addition to property and contract as categories of restriction on the negotiation of information, there always remains in the background the government's power to regulate transfers of information. How much power the government has in this context, and how frequently it will be used, have yet to be determined.

A leading example of a regulatory restraint on the negotiation of information is the Toysmart.com case. Toysmart.com, an Internet-based retailer of toys, collected information about its customers in the ordinary course of business. Not unlike other etailers in the late 1990 s, toysmart.com promised customers that "[p]ersonal information voluntarily submitted by visitors to our site, such as name, address, billing information and shopping preferences, is never shared with a third party."199

On June 9, 2000, creditors forced toysmart.com into bankruptcy. ${ }^{200}$ Prior to bankruptcy, toysmart.com had sought to sell its assets in order to raise funds to pay obligations. Among other things, toysmart.com put up for sale its databases, customer lists, marketing plans, web site content, software and intellectual property. ${ }^{201}$ Consumers, privacy activists and others objected to the sale. ${ }^{202} \mathrm{On}$ July 21,2000 , the FTC sued toysmart.com to restrain the sale, claiming that the sale of the customer lists was prohibited under 15 U.S.C. $\$ 45$ (a) as an "unfair or deceptive act[] or practice[] in or affecting commerce." 203

Shortly thereafter, toysmart.com entered into a settlement agreement with the FTC, which allowed it to sell its customer list to a buyer "in a related market."204 Ulimately, the list was purchased for $\$ 50,000$ by Walt Disney, one of toysmart.com's investors, and destroyed, leaving the "“underlying legal issues ...

${ }^{199}$ Federal Trade Commission Complaint $\mathbb{9}$ 9, Fed. Trade Comm'n v. Toysmart.com, L.L.C., No. 00-CV11341 (D. Mass. Aug. 21, 2000), available at http://www.ftc. gov/os/2000/07/toysmartcmp.htm [hereinafter FTC Toysmart Complaint].

200 FTC Toysmart Complaint, supra note 199, II 12.

201 Greg Sandoval, Failed Dot-coms May be Selling Your Private Information, CNET NEws.COM, at http://news.com.com/2100-1017-242649.html (June 29, 2000).

202 Greg Sandoval, FTC files complaint against Toysmart, CNET NEwS.COM, at http://news.com.com/2100-1017-242950.html (July 10, 2000).

203 FTC Toysmart Complaint, supra note 199, 9सा 14-15.

204 FTC Approves Pact Allowing Toysmart's Customer-List Sale, WALL ST. J., July 24, 2000 , at A28. However, the restrictions agreed to were subsequently overturned by U.S. Bankruptcy Judge Carol Kenner, who ruled that restricting the sale to a particular type of buyer was premature and counterproductive. Jerry Guidera \& Frank Byrt, Judge Refuses to Set Conditions on Toysmart Sale, WALL ST. J., Aug. 18, 2000, at B6. 
unresolved," in the words of Harry Murphy, the bankruptcy trustee in the case. ${ }^{205}$

In the context of biological information, the Health Insurance Portability and Accountability Act of 1996 (HIPAA) will restrain negotiability of personally identifiable health information. ${ }^{206}$ HIPAA purports to set forth the nation's first comprehensive privacy protection for personal health information. ${ }^{207}$ HIPAA requires the development and promulgation of regulations to "protect the privacy of individually-identifiable health records in any form (including electronic, paper and oral) through disclosure and use limitations, fair information practices, and privacy and security policies that apply to 'covered entities' (meaning health providers, health insurance plans and health care clearinghouses) and their business associates." 208 Among other things, those who collect personally identifiable health information must obtain (i) the consent of the subject for transactions that are standard in the delivery and payment of health care services; and (ii) authorizations for the disclosure of personal health information for nonhealth care purposes. ${ }^{209}$ The force of HIPAA in the future is uncertain, as new regulations have been proposed that would appear to limit its protections. ${ }^{210}$

Another regulatory restraint on the negotiability of personal information will come from federal banking law. The Federal Financial Services Modernization

205 Greg Sandoval, Judge OKs Destruction of Toysmart List, CNET NEwS.COM, at http://news.com.com/2100-1017-251893.html (Apr. 15, 2001). More recently, Egghead.com filed for bankruptcy after selling its assets-including its customer list- to Fry's Electronics. See Troy Wolverton, Egghead to File for Bankruptcy, CNET NEWS.COM, at http://news.com.com/2100-1017-271685.html (Aug. 15, 2001); Troy Wolverton, Egghead Sale Could Crack on Privacy Issues, CNET NEws.COM, at http://news.com.com/2100-1017272130.html (Aug. 24, 2002).

206 Health Insurance Portability and Accountability Act of 1996, Pub. L. No. 104-736 $\S 2713,110$ Stat. 1936 (1996) [hereinafter HIPAA].

207 See Press Release, President George W. Bush, at http://www.whitehouse.gov/news/ releases/2001/04/20010412-1.html (Apr. 12, 2001); Press Release, Secretary Tommy G. Thompson, Statement by HHS Secretary Tommy G. Thompson Regarding the Patient Privacy Rule, at http:// www.hhs.gov/news/press/2001pres/20010412.html (Sept. 16, 2002).

208 Lawrence O. Gostin et al., Balancing Communal Goods and Personal Privacy Under a National Health Informational Privacy Rule, 46 ST. LouIS U. L.J. 5, 5-6 (2002). Prior to HIPAA there was no apparent constitutional right to privacy of personal health information. See, e.g., Whalen v. Roe, 429 U.S. 589, 606 (1977) (upholding New York public health database containing pharmaceutical records).

209 See Standards for Privacy of Individually Identifiable Health Information, 65 Fed. Reg. 82,462, 82,509-10 (Dec. 28, 2000) (codified at 45 C.F.R. pts. 160, 164).

210 See Press Release, United States Dep't of Health and Human Servs., HHS Proposes Changes that Protect Privacy, Access to Care, at http://www.hhs.gov/news/press/2002pres/ 20020321 html (discussing changes to regulations that would remove patient consent requirements before certain transactions in patient information) (last visited Oct. 28, 2002). 
Act (also known as the Gramm-Leach-Bliley Act-“"GLBA"), ${ }^{211}$ signed into law on November 12,1999, requires financial services companies, such as banks and lending institutions, to send their customers an annual privacy statement with the right to "opt out" of having the company share their personal information with third parties. GLBA does not give consumers the right to prevent companies from sharing their information with affiliated companies, which may include marketing companies with which the company has a relationship. ${ }^{212}$

The regimes that restrain the negotiation of information are not mutually exclusive. The property and contract regimes interact closely; tort, although not discussed separately, plays an important role as well. Although federal regulation should clear the field of state common law and regulatory restraints on negotiability, it is difficult to imagine that the federal government will regulate all information transactions all the time.

Restraints on negotiability do not always destroy value. Some restraints will enhance information value under certain circumstances. If the patent and copyright rules did not create a limited monopoly in the author or inventor, there would likely be a diminished incentive to invent or create. Conversely, the weakness of trade secret protection may be viewed as an impediment to negotiation, to the extent that it reduces incentives to make and traffic in valuable data compilations.

The relative strengths and weaknesses of the various regimes also affect the secondary market for information assets. Absent monopoly protection, there would be little or no incentive (or requirement) to pay (via license fees) for protected works. The success of the ProCDs of the world depends, in part, on the willingness of courts to enforce contractual restraints in shrinkwrap licenses. These restraints, they would say, create value (at least for the ProCDs). The trade secret regime, by contrast, may reduce incentives to pay for databases, although it may not limit traffic per se.

Most of these restraints arise for reasons largely unrelated to commercial utility. ${ }^{213}$ These restraints may reflect the invention incentives of patent or copyright law, or the desire to protect personal privacy. Commercial law, by contrast, is motivated by the desire to promote traffic in subject property. ${ }^{214}$ Thus, it should be no surprise that commercial law restraints on the negotiability of

211 Gramm-Leach-Bliley Act, Pub. L. No. 106-102, § 740, 113 Stat. 1338, 1480-81 (1999) (codified throughout Titles 12, 15, and 18 of the U.S.C).

21215 U.S.C. $\$ \S 6801-6809$ (2000).

213 ProCD, Inc. v. Zeidenbverg, 86 F.3d 1447 (7th Cir. 1996), and UCITA, supra note 178 , may be exceptions to this.

214 See, e.g., U.C.C. \& 1-102(2)(b) (2001) ("[T] he [u]nderlying purposes [of the U.C.C. include] . . . the continued expansion of commercial practices through custom, usage and agreement of the parties."). 
information generally reflect different legal goals and are intended to protect different kinds of participants in the commercial system.

\section{REMOTE CONTROL-ARTICLE 9 AND THE NEGOTIABILITY OF INFORMATION}

Restraints on the negotiability of information will not arise solely under the property, contract, and regulatory regimes described above. These restraints have received the most attention to date because most fights about the commercial utility of information are waged within those constructs. But even greater, if less fully appreciated, restraints exist in Article 9 of the Uniform Commercial Code. Article 9 of the U.C.C. will likely present unique challenges to the developing commercial market for information because of the ease with which security interests in information assets will arise and their durability after attachment.

\section{A. Article 9 as Restraint on Negotiability}

A security interest is any interest in personal property that secures payment or performance of an obligation. ${ }^{215} \mathrm{~A}$ security interest is not enforceable against anyone - the debtor, the debtor's creditors or other third parties-unless and until it has "attached."216 Ordinarily, three things must occur for a security interest to attach: (i) "value has been given"217 (ii) "the debtor has rights in the collateral"218 and (iii) the debtor has executed a security agreement that describes the collateral. ${ }^{219}$ After all three things have occurred, the security interest is enforceable against the debtor. ${ }^{220}$

In general, the security interest will be enforceable against third partiescreditors of, and purchasers from, the debtor-if it has been "perfected."221 Although "perfection" is not defined in Article 9, it generally occurs where the secured party either takes possession or control of the collateral, or gives public notice of its security interest by filing a form known as a U.C.C.-1 financing statement in the appropriate state office (usually the office of the secretary of state). ${ }^{222}$

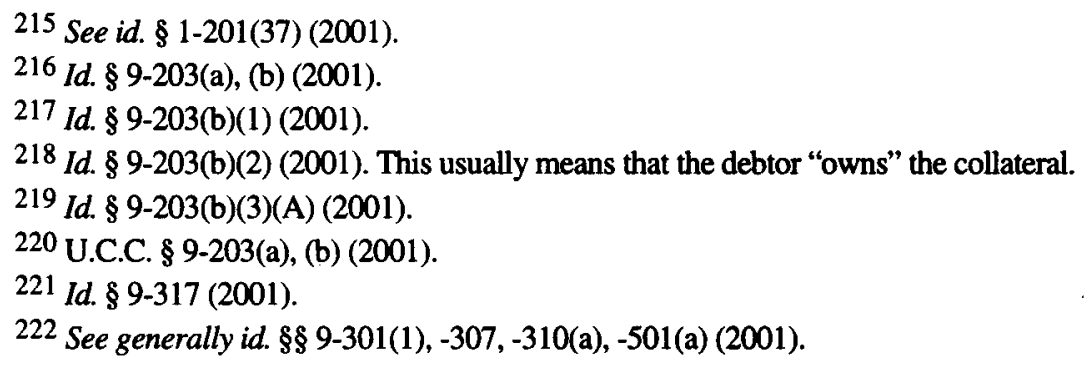


The "security" of the interest derives ultimately from the secured party's enforcement rights, provided in part 6 of Article 9, and from remedies contained in the contract governing the security interest, known as the security agreement.223 These remedies most famously include the right to take "possession" of collateral upon debtor default (assuming the secured party can do so without breach of the peace). ${ }^{224}$ The secured party may also collect collateral and proceeds of collateral from account debtors and other persons obligated on collateral and proceeds. ${ }^{225}$ The secured party may also, subject to certain debtor and third party protections, either sell or otherwise dispose of the collateral and apply the proceeds of the disposition to satisfy the secured debt or retain the collateral in satisfaction of the secured debt. ${ }^{226}$

We do not typically consider Article 9 to be a restraint on negotiability, but this is probably a mistake. Article 9 restrains negotiability by virtue of three sets of rules: (i) the rule of "general effectiveness" of security agreements, (ii) the specific rule that security interests continue notwithstanding dispositions of collateral, and (iii) rules on proceeds of collateral. Together, these rules generally provide that a security interest will continue in collateral notwithstanding sale, exchange, or other disposition, and will expand to cover "proceeds"-other value created by the disposition. Because information assets are so highly mobile and readily replicable, security interests in information assets should travel as far and as wide as the information assets themselves. The easy diffusion and great durability of security interests in information assets will create unprecedented problems of remote control.

\section{Rule of Effectiveness}

The remote control analysis begins with U.C.C. section 9-201. Like former Article 9, revised section 9-201(a) provides that "[e]xcept as otherwise provided in [the Uniform Commercial Code], a security agreement is effective according to its terms between the parties, against purchasers of the collateral, and against creditors." 227 This rule of "general effectiveness" has been called the "'golden rule" 228 of Article 9 because it is central to the strength of a security interest. By its terms, it purports to apply the agreement of the secured party and the debtor to the rest of the world-purchasers of the collateral and other creditors of the

${ }^{223}$ Id. § 9-102(a)(73) (2001).

224 Id. § 9-609(a), (b) (2001).

225 Id. § 9-607 (2001).

226 U.C.C. $\$ 9-610,-620(2001)$.

227 Id. § 9-201(a) (2001).

228 Allegaert v. Chem. Bank, 657 F.2d 495, 508 (2d Cir. 1980) (quoting J. WHTTE \& R. SUMMERS, HANDBOOK OF THE LAW UNDER THE UNIFORM COMMERCIAL CODE $§ 25-12$, at 938 (1972)). 
debtor. 229 I will call it the "Rule of Effectiveness." This is a fairly bold idea, as our law generally provides that two parties cannot, by their contract, bind a third party not in privity. ${ }^{230}$

\section{Rule of Continuity}

Perhaps uncertain that the Rule of Effectiveness would be taken seriously, 231 the drafters of revised Article 9 (like the drafters of former Article 9) also provided a specific continuity rule for security interests themselves. Revised section 9-315(a)(1) provides that "a security interest . . . continues in collateral notwithstanding sale, lease, license, exchange or other disposition thereof unless the secured party authorized the disposition free of the security interest." 232 I will call this the "Rule of Continuity."

Former Article 9 contained a similar Rule of Continuity, although it lacked the precision of revised section 9-315.233 Former section 9-306(2) provided that

${ }^{229}$ See U.C.C. \$ 9-201 cmt. 2 (2001) ("With certain exceptions a security agreement is effective between the debtor and the secured party and is likewise effective against third parties."); see also U.C.C. \$ 9-201 cmt. 2 (1972) ("In general the security agreement is effective between the parties; it is likewise effective against third parties.").

230 See Elizabeth Warren, Making Policy with Imperfect Information: The Article 9 Full Priority Debates, 82 CORNELL L. REV. 1373, 1375 (1997) ("Ordinarily, when two parties try to alter the rights of third parties who are absent from the negotiations and who are unable to refuse such altered treatment, the law says 'no."').

231 Scholars who considered the Rule of Effectiveness under former Article 9 seemed reluctant to take it at face value. For example, Professors Baird and Jackson observed that "despite [former section] 9-201's bold assertion that only other provisions of the [U.C.C.] override it, obviously other statutory law ... must be considered." DOUGLAS G. BAIRD \& THOMAS H. JaCKSON, SECURITY INTERESTS IN PERSONAL PROPERTY 367-68 (1984). Similarly, Professor Gilmore explained that "[i]f the [Uniform Commercial] Code had described itself as the exclusive source of law, we may doubt that the description would have been taken seriously, even for literary purposes. But it does not." 1 GLMORE, supra note 75, at 472.

232 U.C.C. \$ 9-315(a)(1) (2001). Thus, a secured party’s rights in collateral are not strictly derivative of the debtor's. While a security interest cannot attach unless the debtor has "rights" in the collateral, $\S 9-203(\mathrm{~b})(2)$, the security interest will continue even after the debtor has conveyed whatever rights it might have had.

A clever, if somewhat disingenuous, statutory response would be to observe that the term "debtor" is defined as "a person having an interest, other than a security interest, in collateral ...." $\S 9-102(a)(28)$. Thus, absent a statutory or contractual cutoff, every transferee from an original debtor will also be a "debtor" under the statute, even though they were not the party that created the security interest. Although correct as a matter of statutory construction, it is a bit disingenuous because it begs the basic question: Should remote parties that acquire collateral in good faith and without knowledge of the prior security interest be treated as the "debtor" of a secured party far back in the chain of production?

${ }^{233}$ See U.C.C. \$ 9-306(1) (1972). The revision is more restrictive than former section 9306 , which was construed to strip a security interest when a secured party "authorized" the 
"a security interest continues in collateral notwithstanding sale, exchange or other disposition ... unless the disposition was authorized by the secured party in the security agreement or otherwise." Since secured parties rarely "authorize" dispositions of collateral in the security agreement, ${ }^{234}$ courts occasionally find that the secured party's conduct "otherwise" authorized the disposition of the collateral free of the security interest. ${ }^{235}$ This proved disturbing to secured parties, who believed that their forbearance on one occasion should not form the basis for punishment in the future. Revised section 9-315(a)(1) lacks the troublesome words "in the security agreement or otherwise" found in former Article 9, perhaps to make the waiver inference less enticing. ${ }^{236}$

\section{Proceeds}

Security interests do not simply continue in collateral (absent a consensual or statutory cutoff); they also generate other security interests in proceeds. And, unlike a security interest in original collateral, none of the three attachment elements need be met for the proceeds security interest to attach. Rather, under revised sections 9-203(f) and 9-315(a)(2), the security interest in proceeds attaches automatically, as and when the proceeds of the original collateral arise. ${ }^{237}$

Although revised Article 9 has not changed the general approach to the attachment of a security interest in proceeds, it has greatly expanded the definition of proceeds to capture, whenever possible, property related to original

disposition. Under section 9-315(a)(1) of the revision, the security interest continues in collateral even if the secured party authorizes the disposition. Authorizing the disposition should not free the collateral of the security interest. Only if the secured party expressly releases its security interest under section 9-315(a), or the ordinary course cutoff rules discussed below apply, will the security interest cease.

234 With one important exception: Inventory lenders often give express permission to the debtor to dispose of collateral, at least in certain circumscribed ordinary course transactions. See BarkLEy Clark, THE LAW OF SECURED TRANSACTIONS UNDER THE UNIFORM COMMERCIAL CODE, II 3.02(3)(b), at 3-14 (2000); see also Steven O. Weise, U.C.C. Article 9: Personal Property Secured Transactions, 56 Bus. LAw. 1835, 1847 (2001) (discussing contractual provisions regarding ondinary course sales).

235 See, e.g., Nat'l Livestock Credit Corp. v. Schultz, 653 P.2d 1243 (Okla. Ct. App. 1982).

236 The official comment observes that revised section 9-315 is "not intended to address the frequently litigated situation in which the effectiveness of the secured party's consent to a disposition is conditioned upon the secured party's receipt of proceeds. In that situation [revised section 9-315](a) leaves the determination of authorization to the courts." $\S 9-315 \mathrm{cmt} .2$ (2001).

237 See Richard L. Barnes, Tracing Commingled Proceeds: The Metamorphosis of Equity Principles into U.C.C. Doctrine, 51 U. PITT. L. REV. 281, 286 (1990). 
collateral. ${ }^{238}$ Under former Article 9, a security interest attached to "identifiable proceeds" "upon the sale, exchange, collection or other disposition of collateral or proceeds."239 Former Article 9 did not define the terms "identifiable" or "disposition," and the meaning of these terms was often litigated. 240 Revised Article 9 solves at least one of these problems by eliminating the requirement that there be a "disposition" of collateral for the proceeds security interest to arise.241 Rather, a disposition is only one of several ways that a proceeds security interest will arise.

Revised Article 9 expands the definition of proceeds in four ways of significance to the negotiability of information. First, revised section 9$102(\mathrm{a})(64)(\mathrm{A})$ defines proceeds as including, among other things, "whatever is acquired upon the ... license ... of collateral."242 This means that licenses of original collateral are proceeds of original collateral. Under revised Article 9, a license of a copyright or patent, for example, should be "proceeds" of the original collateral. ${ }^{243}$

Second, revised section 9-102(a)(64)(A) clarifies that the secured party may pursue proceeds in the hands of parties other than the debtor. The Revision pointedly uses the passive tense- "whatever is acquired"-and lacks an indirect object $^{244}$ (e.g., "by somebody") because the Revision empowers secured parties to pursue proceeds in the possession or control of persons other than the debtor.

238 Comment 13 to section 9-102 explains that "[t]he revised definition of 'proceeds' expands the definition beyond that contained in former section 9-306." $\$ 9-102 \mathrm{cmt}$. 13 (2001).

239 §§ 9-306(1), -306(2) (1972).

240 See, e.g., In re Hastie, 2 F.3d 1042 (10th Cir. 1993) (non-liquidating dividends); In re Transp. Design and Technology, Inc., 48 B.R. 635 (Bankr. S.D. Cal. 1985) (patent not proceeds of patent application collateral because there is no "disposition" of application).

241 See § 9-102(a)(64)(A) (2001).

242 Id. \$ 9-102(a)(64)(A) (2001).

243 Compare In re Transp. Design and Tech., Inc., 48 B.R. at 640 (declining to treat patent as proceeds of patent application under former Article 9), with Lipson, supra note 87, at 1135-36 (questioning continued viability of Transportation Design rule in light of revised Article 9).

This provision should also overrule cases that held that leases of property subject to a security interest were not proceeds. See, e.g., In re Corpus Christi Hotel Partners, 133 B.R. 850, 856 (Bankr. S.D. Tex. 1991); In re Keneco Fin. Group, 131 B.R. 90,94 (Bankr. N.D. Ill. 1991); In re Inv. Hotel Props., 109 B.R. 990, 995-96 (Bankr. D. Colo. 1990); In re A.E.I. Corp., 11 B.R. 97, 100-02 (Bankr. E.D. Pa. 1981); In re Cleary Bros. Constr. Co., 9 B.R. 40, 41 (Bankr. S.D. Fla. 1980). But see In re S. Equip. Sales Co., 24 B.R. 788, 794 (Bankr. D. N.J. 1982) (characterizing sums paid upon leases of inventory collateral as proceeds received upon disposition of such collateral).

${ }^{244}$ For those who, like the author, are grammar-challenged, an indirect object "is the target of the action." The Languages Made Clear Project, Grammar Chapter: Indirect Object Pronouns, at http:/home.wanadoo.nl/ mvgompel/indirectobjectpronouns_es_en.html (last visited Oct. 28, 2002). 
Courts applying former Article 9 had come to this conclusion, 245 but the Official Comment emphasizes the point: "This Article contains no requirement that property 'be received' by the debtor for the property to qualify as proceeds."246 This means that third parties that come into proceeds will, like those who acquire encumbered original collateral, take subject to the prior security interest (unless otherwise cut off).

Consider again the abstracted characters $D, S P$, and $B / L^{1}$, from the introduction to this article. If D granted a security interest in its inventory to SP, and also collected information about customers when it sold inventory, it would be reasonable to conclude that the information was "proceeds" of the inventory. If $D$ then sold or licensed the list of customer data to $B / L^{1}$, whatever $B / L^{1}$ received from $\mathrm{B} / \mathrm{L}^{2}$ for the sale or license of the list to $\mathrm{B} / \mathrm{L}^{2}$ would also be proceeds, subject to SP's security interest. If D's original list thus made its way to many other buyers or licensees $\left(B / L^{\infty}\right)$, each and every transferor would receive "proceeds" to which SP would have recourse, according to revised section 9102(a)(64). The mobility of this kind of information, in other words, expands the reach of proceeds beyond anything contemplated to date.

Third, revised section 9-102(a)(64)(C) provides that proceeds include "rights arising out of collateral."247 This cryptic phrase is not explained in the Official Comment. It may, however, be quite expansive and pick up all kinds of rights associated with original collateral, including intangible rights in technologies and data associated with original collateral. ${ }^{248}$ I have argued elsewhere that this should mean that a patent is proceeds of a trade secret, and a derivative work under the Copyright Act is proceeds of a security interest in a copyright. ${ }^{249}$ In both cases, the later rights "arise out of" the earlier rights. This is one reason security interests in information assets will arise covertly. It is highly unlikely that a debtor granting a security interest in one copyright understands that it is, as a matter of law, also granting a security interest in all derivative works it later produces. $^{250}$

245 See, e.g., Centerre Bank, N.A. v. New Holland Div. of Sperry Corp., 832 F.2d 1415 (7th Cir. 1987); In re Guaranteed Muffler Supply Co., 27 U.C.C. Rep. Serv. (CBC) 1217 (Bankr. N.D. Ga. 1979); Eastern Idaho Prod. Credit Ass'n v. Idaho Gem, Inc., 842 P.2d 282 (Idaho 1992); First State Bank v. Clark, 635 N.W.2d 29 (Iowa 2001). There was, however, a split of authority on the issue. See First State Bank, 635 N.W.2d at 30 (discussing split).

246 § 9-102 cmt. 13(d) (2001).

247 Id. $\$ 9-102(\mathrm{a})(64)(\mathrm{C})(2001)$.

248 See Lipson, supra note 87, at 1132-38.

${ }^{249}$ Id.

250 Of course, to the extent the debtor simply granted a security interest in "general intangibles," all copyrights would be covered, whether or not derivative works. Moreover, as discussed in note 168 supra, the instability of the rules on perfecting security interests in intellectual property may provide some cover for debtors who unwittingly grant security 
Finally, revised section 9-102(a)(64)(D) provides that damage claims arising out of the "infringement of rights in" collateral are proceeds, at least "to the extent of value of [the] collateral." 251 This subsection provides explicitly what section 9102(a)(64)(C) only implies: namely, that a claim for infringement of rights associated with original collateral (e.g., patent and copyrights) will be proceeds. As with all remote security interests, the damage claim that is proceeds may be asserted against the debtor, a licensee of the debtor or, in theory, anyone infringing the debtor's rights in the original collateral.

Revised Article 9 also clarifies when proceeds will be "identifiable," and thus subject to a proceeds security interest. For this purpose, the Revision distinguishes between goods and other types of collateral that are commingled. In the case of commingled goods that are proceeds, the Revision provides that a security interest attaches to the product or mass with which the collateral is commingled."252 "If collateral becomes commingled goods, a security interest attaches to the product or mass," 253 and is perfected if the security interest in the collateral was perfected prior to commingling. ${ }^{254}$ Where commingled goods are proceeds and subject to competing perfected security interests, the security interests shall "rank equally in proportion to the value of the collateral at the time it became commingled."255

In the case of commingled proceeds other than goods (e.g., cash or general intangibles), the Revision provides that proceeds will be "identifiable" "to the extent that the secured party identifies the proceeds by a method of tracing, including application of equitable principles, that is permitted under law other than this article with respect to commingled property of the type involved."256 The Revision therefore contemplates that secured parties may trace their security interest in commingled cash proceeds using, for example, the "lowest intermediate balance" test. 257

To understand the reach of the CIPs Rules, consider Fairview State Bank v. $E d w a r d s, 258$ where the court held under former Article 9 that a security interest in cows extended to embryos produced by the cows, and apparently followed the embryos into fully grown calves.

interests in derivative works. The security interest may attach automatically, by virtue of the proceeds rules, but would have little practical force if not perfected.

$251 \S 9-102(\mathrm{a})(64)(\mathrm{D})(2001)$.

252 Id. $\$ 9-336$ (c) (2001). Section 9-336(a) of the revision provides that "commingled goods" are "goods that are physically united with other goods in such a manner that their identity is lost in a product or mass."

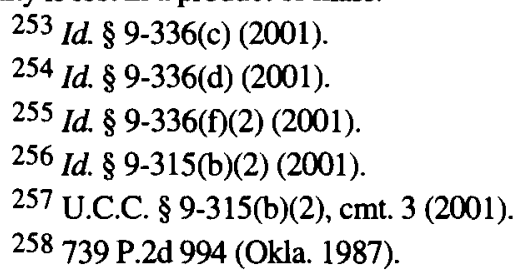


In $E d w a r d s$, the debtors ran a ranch on which they raised cattle. They were parties to a contract with Granada Land and Cattle Company pursuant to which the "debtors agreed to send Granada twelve "donor cows" that had been determined to be "suitable for an embryo transfer procedure" that Granada would perform. 259 "Granada [would] give fertility drugs to the [D]ebtors' cows in order to speed up egg production. Granada [would then] select bulls to mate [with] the [D]ebtors' cows." 260 One week after insemination, the fertilized eggs would be "flushed" from the donor cows and transferred to a recipient cow that would act as a "surrogate mother" for the donated embryo. ${ }^{261}$ Granada paid the debtors $\$ 500$ per successful pregnancy. The purchase price entitled Granada to acquire both the embryo and the calf produced from it. ${ }^{262}$

The debtors owed money to Fairview State Bank and the United States Government, through the Farmers Home Administration (FmHA). Both obligations were secured by security interests in the donor cows. ${ }^{263}$ Although the debtors did not dispute that the calves were the "product" of the donor cows, they did claim that these security interests did not extend to Granada's payments to the debtors for embryos acquired from the donor cows. ${ }^{264}$ As support for their position, the debtors noted that none of the parties had contemplated anything like the embryo donor program and that, in any case, the security agreements did not provide for a security interest in the "products" or the proceeds of the cows.

The court first determined that the secured parties' security interests attached to the embryos. Although the FmHA security agreement appeared to lack a proceeds clause, it did give the government a security interest in the debtors' "after acquired property," (i.e., in "[a]ll livestock ... [and] other farm products ... now owned or hereafter acquired ... together with all increases ... and additions thereto.") ${ }^{265}$ The Fairview security agreement contained both afteracquired property and proceeds clauses, providing that the bank's security interest attached to-

[A]ll additions and replacements to the property, along with all proceeds $I$ might receive or be entitled to from the sale of the property.... Also included in this security interest will be proceeds from the sale of the property.... If the property

${ }^{259}$ Id. at $995-96$.

260 Id.

261 Id. at 996.

262 Id. Based upon the flushing and donation technology used by Granada, the debtors' cows were expected to be able to be inseminated five times per year. Id. at 997-99.

263 Id. at 996.

264 Fairview State Bank v. Edwards, 739 P.2d 994, 996 (Okla. 1987).

265 Id. at 997. 
I have pledged as collateral includes livestock, I grant to the bank a security interest in all increases in that livestock 266

The court first considered, and rejected, the debtors' claim that the embryos themselves were not collateral. Although the parties may not have contemplated the embryo program, the embryos were nevertheless subject to the security interests as both "after-acquired property" and "increase" in the original collateral. ${ }^{267}$ "Although the process by which the fertilized embryos are removed from Debtors' cows and inserted into recipient cows is unusual," the court observed, "the contract between Debtors and Granada is relatively simple.... Granada agreed to purchase embryos produced by Debtors' donor cows; i.e., to buy the unborn offspring of the Debtors' cows."268

The court then considered whether Granada's payments to the debtors were proceeds of the cows under former section 9-306. Reciting the statutory formulation ("'proceeds' includes whatever is received upon the sale, exchange, collection or other disposition of collateral ...") the court concluded that the cash payments were proceeds. 269

One could have taken a different approach. Under former Article 9, there was some support for the view that a proceeds security interest attached only if there was a "disposition" of the original collateral. Absent a "disposition," no proceeds security interest would attach. ${ }^{270}$ On that view, which came to be known as the "exchange or replacement" view of proceeds, 271 "title" to the collateral had to pass before the proceeds security interest could arise. In Edwards, the debtor still had "title" to the original collateral, the cows. On the "exchange or replacement"

266 Id.

267 "Increase" the court reasoned, includes "the issue or offspring of animals." Id. at 998 (citing BLACK's LAW DiCTIONARY (5th ed. 1979)).

268 Id. at 998 . The court also observed that cow embryos appear to fall within the definition of goods. "The Uniform Commercial Code Comments following § 2-105(1) note that the young of animals are expressly included in the definition of goods because 'they, too, are frequently intended for sale and may be contracted for before birth."' Id.

269 ld. at 999.

270 See, e.g., In re K.L. Smith Enter. Ltd., 2 B.R. 280 (Bankr. D. Colo. 1980) (holding chickens are livestock and eggs are products of livestock under Uniform Commercial Code and did not constitute inventory, or proceeds of inventory of, debtor).

271 See Permanent Editorial Bd. FOR tHe Unif. COMmercial Code, PEB STUdy GROUP UNIFORM COMMERCIAL CODE ARTICLE 9: REPORT 110-11 (1992) Thereinafter PEB REPORT]. The Permanent Editorial Board (the "PEB") has been established by the American Law Institute and the National Conference on Commissioners of Uniform State Laws to study and propose appropriate revisions to the Uniform Commercial Code. See also R. Wilson Freyermuth, Rethinking Proceeds: The History, Misinterpretation and Revision of U.C.C. Section 9-306, 69 TuL. L. REV. 645, 692-93 (1995). 
view, no disposition would have occurred. Thus, no proceeds security interest would have arisen.

A more basic question - which the court dodged as not having been raised by the parties-was whether the security interest would have continued in the embryos had they been sold to a third party purchaser. ${ }^{272}$ It appears that the security interest would have continued because it is unclear how the court could have found a proceeds security interest in payments on account of the fertilized embryos themselves, if there was not also a security interest in them. Put another way, Granada was paying for embryos, not cows. If these payments were "proceeds," then they must have been proceeds of the embryos (as well as of the cows).

Had the court considered the issue under revised Article 9, it would likely have come to the same conclusion. As discussed above, the Rule of Effectiveness, the Rule of Continuity and the rules on proceeds should, collectively or respectively, be read to conclude that, one way or another, the security interest in the cow continues in the embryo. It may be that the embryo is treated as an extension of the original collateral. It may instead be that the embryo is proceeds of the cow. While the production of embryos may not have resulted in a "disposition" of the original cow, surely the owner's rights in the embryos were "rights arising out of" the collateral (the cow). ${ }^{273}$ Those rights would then become collateral (as proceeds) for the secured party.

Under the CIPs Rules, security interests will arise easily and often unexpectedly. It is easy to imagine that the Edwards case stands for the proposition that the embryo is not only a continuation or proceeds of the cow but also is the cow's cell-line. If so, products developed from the cell line should also be a continuation or proceeds of the original collateral, and should thereafter continue into biological materials produced from the cell line. Is the patent on the pharmaceutical derived from the cell line of the encumbered cow proceeds of the original security interest? What about an electronic database of information about the cell lines of many encumbered cows?

\section{B. Statutory Responses and Cutoffs}

Article 9 is not an undifferentiated enemy of negotiability. Article 9 does recognize the merits of free negotiability and provides several avenues by which collateral may be disposed of unencumbered. Unfortunately, these paths to free negotiability (often called "cutoffs," because they cut off the security interest)

272 Edwards, 739 P.2d at 995 , n.1 ("[B]ecause the issue was not raised by the parties, we do not address the question of whether the Debtors made an unauthorized disposition of the collateral so that the third-party buyer took the embryos produced by Debtors' donor cows subject ... [to the] security interest.")

273 U.C.C. $\$ 9-102(a)(64)(C)(2001)$. 
were designed with goods, not intangibles, in mind. Because information will usually be general intangibles, these cutoffs will not liberate much information from the remote control of prior secured parties.

The general rule on the negotiability of information subject to an Article 9 security interest is found in U.C.C. section 9-321. This section provides that one acquires rights in information free of a prior Article 9 security interest only if one is a "licensee in ordinary course" under a "nonexclusive license" of general intangibles, and then only to the extent the security interest was created by the licensor.

\section{1. "Licensee in Ordinary Course"}

To enjoy free negotiability of information, one must first be a "licensee in ordinary course." A "licensee in ordinary course" is defined as "a person that becomes a licensee of a general intangible in good faith, without knowledge that the license violates the rights of another person in the general intangible, and in the ordinary course of business from a person in the business of licensing general intangibles of that kind." 274 This cutoff purportedly "reflects the expectations of the parties and the marketplace: a licensee under a nonexclusive license takes subject to a security interest unless the secured party authorizes the license free of the security interest or other, controlling law such as that of this section (protecting ordinary-course licensees) dictates a contrary result."275 Section 9-321 appears to attempt to balance the secured party's ability to have recourse to intangible collateral against the ordinary-course licensee's expectation that it will be able to use the intangible property free of concern about the existence of security interests. 276

Businesses that generate information for resale would not necessarily be "in the business" of generating information of "that kind." Consider again the case of toysmart.com. As noted above, toysmart.com was an etailer that sought to sell its customer database despite having promised its customers that it would not do

${ }^{274}$ Id. \$ 9-321(a) (2001).

275 Id. \$ 9-321 cmt. 2 (2001).

276 See Steven O. Weise, The Financing of Intellectual Property Under Revised UCC Article 9, 74 CHI.-KENT L. REV. 1077, 1100 (1999). The theory may also reflect assumptions about the nature of bargaining. In an exclusive license, the parties will more likely be represented by counsel, and will certainly negotiate some or all of the terms. As noted above, nonexclusive licenses appear to function more like commodities or adhesion contracts, and tend not to be the subject of much bargaining. Thus, the non-debtor licensee is less likely to have an opportunity to negotiate for a contractual remedy as against the secured party who might claim an interest in the licensed intangible. 
so. 277 The party that sought to "negotiate" this information was the debtor's bankruptcy trustee. But the bankruptcy trustee would have had little reason to try to sell the database if it were subject to a prior Article 9 security interest. ${ }^{278}$ Because the database was composed of information that toysmart.com received on disposition of its inventory, the database would have been proceeds of a security interest in the inventory. A purchaser of the database therefore would acquire it subject to this security interest, unless the security interest was cut off by statute or agreement of the secured party. ${ }^{279}$

Under former Article 9, there was no statutory cutoff for dispositions of intangibles. As noted above, section 9-321 of the Revision does cut off an "ordinary course" license of a general intangible. But that section will not cut off a security interest in a general intangible that is sold outright. Nor will it cut off a security interest where the licensor was not "in the business" of licensing intangibles "of that kind." In the case of toysmart.com, the debtor was probably not "in the business" of licensing anything-it sold toys.

The "in the business" problem is not limited to etailers. As noted above, businesses constantly exchange information through Electronic Data Interchanges (EDI), business-to-business web sites (B2B), business-to-consumer exchanges (B2C) and private business exchanges. In virtually all of these cases, the party that generates the information will not be "in the business" of generating and licensing information of that kind. It will, instead, be in some other, primary business.

Nor is the "in the business" problem limited to business information. It will be difficult to know what "business" companies like Celera are in. The "Online Information Business" component of Celera is, according to the company, "a leading provider of information based on the human genome and related biological and medical information." 280 Does this mean that it is a research

277 Toysmart.com promised that "[p]ersonal information voluntarily submitted by visitors to our site, such as name, address, billing information and shopping preferences, is never shared with a third party," and "[w]hen you register with toysmart.com, you can rest assured that your information will never be shared with a third party." See FTC Toysmart Complaint, supra note 199, II 9.

278 This assumes that there was no equity in the database. To the extent that the value of the database exceeded the value of the secured claim encumbering the database, the bankruptcy trustee would have an economic incentive to sell it, to capture the value of the equity for the benefit of the debtor's estate. See 11 U.S.C. $\$ \$ 363,506$ (2000) (regarding sales of property of the estate ( $\$ 363)$ and value of secured claims $(\$ 506)$ ).

${ }^{279}$ Asked why the debtor's banks did not make this argument in an attempt to capture whatever value there was in the customer database, Harry Murphy, toysmart.com's bankruptcy trustee responded: “They probably didn't think of it." Telephone Interview with Harry Murphy, Bankruptcy Trustee, toysmart.com (Apr. 29, 2002).

280 Celera, Online Business: Overview, at http://www.celera.com/genomics/home.cfm (last visited Sept. 26, 2002). The company's description continues: "Pharmaceutical, biotechnology, and academic customers use this information, along with customized 
company that incidentally licenses intangibles (patented gene sequences)? Or is it a licensing company that happens to own patented rights to some important information? What about other, more traditional pharmaceutical companies such as Amgen, Novartis, and Pharmacia Corp.? Are they "in the business" of developing and retailing medicines or licensing intangibles or both?

Those seeking to understand what it means to be "in the business" for purposes of cutting off security interests may look to cases on the sale of goods under former Article 9. Former Article 9 (like revised Article 9) provided that a security interest in goods created by the seller would be cut off when the goods were sold to a "buyer in ordinary course" (BIOCOB). ${ }^{281}$ Like prior law, "ordinary course" status is determined by a certain kind of "ordinariness" of the license, not merely the good faith (subjective or objective) of the licensee. Under former Article 9, if a debtor's sale of goods was an isolated incident, it was probably not in ordinary course. ${ }^{282}$ If, however, the debtor was in the business of selling in general, there would be a good argument that the sale of a related line of collateral would be in ordinary course. ${ }^{283}$

The heart of the problem seems to be that the statute defines the licensee's rights by reference to the licensor's behavior. This is an odd way of distributing rights. The more common negotiability models discussed above are generally indifferent to the seller's practices, so long as the seller is not a thief or engaged in fraud. ${ }^{284}$ As information assets transform the nature of businesses, however, it will likely also become increasingly difficult to determine what is ordinary course for those whose business involves these kinds of assets. Companies like toysmart.com and Celera may not be in a single "business" for this purpose.

\section{Nonexclusive License}

Satisfying the ordinary course rules, alone, will not protect the party acquiring information assets. Under the statutory cutoff, the acquiror must also show that the transaction is a "nonexclusive" license. The problem here is that

information technology solutions provided by Celera, to enhance their capabilities in the fields of life science research and pharmaceutical and diagnostic discovery and development." Id.

281 U.C.C. \$ 9-307(1) (1972); U.C.C. \$ 9-320(a) (2001).

282 Cent. Cal. Equip. Co. v. Dolk Tractor Co., 144 Cal. Rptr. 367 (Cal. Ct. App. 1978) (farmer not in business of selling farm machinery); Meyer v. Gen. Am. Corp., 569 P.2d 1094 (Utah 1977) (corporation not in business of selling tractors); Kaw Valley State Bank v. Stanley, 514 S.W.2d 42 (Mo. Ct. App. 1974) (car dealer that sold a boat); Am. Nat'l Bank v. Cloud, 247 Cal. Rptr. 325 (Cal. Ct. App. 1988) (sellers did not regularly sell raisins, rendering buyer not in ordinary course of business).

283 See Foy v. First Nat'l Bank of Elkhart, 693 F. Supp. 747 (N.D. Ind. 1988) (merchants may in ordinary course establish flexible marketing arrangements), aff'd, 868 F.2d 251 (7th Cir. 1989); Bank of Utica v. Castle Ford, Inc., 317 N.Y.S.2d 542 (N.Y. App. Div. 1971).

${ }^{284}$ See § 3-203(b) (2001). See also discussion in Part III.A, supra. 
Article 9 does not define the words "nonexclusive" or "license," and it is not clear where one should look for explication.

Steve Weise, a leading commercial finance practitioner, has suggested that UCITA may guide courts to an understanding of the distinction between an exclusive and nonexclusive license. ${ }^{285}$ UCITA section 102(a)(47) has a narrow definition of "nonexclusive license," and a correspondingly broad definition of an exclusive license. Under UCITA, a license qualifies as "exclusive" if it "precludes" the licensor from entering into another license with another licensee within the same "scope."286 It is not known whether the scope in question refers to time, subject matter, markets, licensees, geography, or some combination of the foregoing. Thus, it may be that the "sale" of a customer list is an exclusive license under UCITA because the seller (licensor) agrees that the buyer (licensee) is the only purchaser of the data in a particular market for a defined period of time.

Given UCITA's uncertain future, one may look instead to copyright law for guidance on the nature of a "nonexclusive license." Under copyright law, which is the intellectual property category most commonly associated with computer software, an exclusive license transfers "full use of the particular rights to the transferee."287 A nonexclusive license of copyright, by contrast, represents "the least substantial of all transfers," 288 and may not convey a "property" interest at all. A nonexclusive license consists merely of permission to use the general intangible, plus (perhaps) other restrictions on the licensee. ${ }^{289}$ Would the "exclusive" right to manufacture a patented product in a particular territory be an exclusive license for Article 9 purposes? Does Article 9 or some other body of law (say, the applicable intellectual property statute) provide the answer? Would analogies from the Patent Act necessarily make sense for this purpose?

It should also be clear that Article 9 creates no cutoff for outright sales or complete assignments of general intangibles. Thus, if I "purchased" information subject to a proceeds security interest, it would remain encumbered by the

285 See Weise, supra note 276, at 1099-100.

286 UCITA, supra note $178, \S 102(a)(47)$.

287 See RAYMOND T. Nimmer, THE LAW OF COMPUTER TECHNOLOGy II 7.02(1), at 7-5 (3d ed. 2000); see also MacLean Assocs., Inc. v. William M. Mercer-Meidinger-Hanson, Inc., 952 F.2d 769, 778-79 (3d Cir. 1991) (holding that nonexclusive license is not a transfer of ownership); Camco Int'l., Inc. v. Perry R. Bass, Inc., 926 S.W.2d 632, 636 (Tex. Ct. App. 1996) (holding that transfer was an assignment, not a license, where contract transferred essentially all rights pertaining to patent).

288 See NIMMER, supra note 287, at 7-6; see also Cohen v. Paramount Pictures Corp., 845 F.2d 851 (9th Cir. 1988); Spindel Fabrik Suessen-Shurr v. Shubert, 829 F.2d 1075 (Fed. Cir. 1987).

${ }^{289}$ See Harris v. Emus Records Corp., 734 F.2d 1329 (9th Cir. 1984) (copyright license); In re Alltech Plastics, Inc., 71 B.R. 686 (Bankr. W.D. Tenn. 1987) (patent license); 17 U.S.C. $\S 101$ (2000). 
security interest, even if I purchased in good faith and without notice of the prior interest.

\section{3. "His Seller/Licensor"}

Even if one is a LIOCOB of a nonexclusive license, one takes free of a security interest only to the extent it was created by the LIOCOB's licensor. If instead the security interest in question was created by someone prior in the chain-say, the person who sold or licensed to the licensor-the LIOCOB cannot, as a matter of law, take free of that earlier security interest. ${ }^{290}$ Under former Article 9, this was known as the "his seller" rule, and applied to sales of goods. ${ }^{291}$ Today, the rule has been cleansed of gender bias and expanded to include licenses of intangibles.

The case of Gordon v. Hamm 292 illustrates the power of the "his seller" rule under former Article 9 as applied to the sales of goods. There, Rick and Llana Hamm borrowed $\$ 144,000$ from Deere Credit, Inc. to purchase a motor home. The Hamms granted Deere a purchase-money security interest in the motor home, which was recorded on the certificate of title. A few months later, the Hamms went to Sunset Motors and traded their unit for another one. Sunset, in turn, sold what had been the Hamms' motor home to Robert and Betty Gordon. The Gordons had borrowed the purchase price from Gentra Capital Corporation. Gentra paid the purchase price to Sunset (the Gordons' seller) without determining whether there was a prior security interest in the home. As sometimes happens in these circumstances, shortly after receiving the purchase price, Sunset went into bankruptcy without ever having paid Deere (the Hamms' lender).

The lower court focused on whether the Hamms' sale of the motor home to Sunset was a "disposition" under former section 9-306(2) (now revised section 9315(a)(1)) that would have cut off Deere's security interest. The lower court held as a matter of law that the sale would be a disposition if it was an "entrustment" by the Hamms. ${ }^{293}$ The lower court left to the jury the question of whether the Hamms had entrusted the motor home to Sunset and, if so, whether Deere had authorized the entrustment. The jury found that the Hamms had entrusted the motor home and that Deere had authorized the entrustment.

Although the jury also found that the Gordons were BIOCOBs under former section 9-307(1), the court of appeals found that to be irrelevant:

290 See § 9-321 (2001).

291 U.C.C. $\$ 9-307$ (1) (1972).

29274 Cal. Rptr. 2d 631 (Cal. Ct. App. 1998).

293 Id. at 632. 
This section [former section 9-307(1); now section 9-320(a)] is of no help to the Gordons, since Deere's security interest was created not by the Gordons' seller (Sunset Motors), but by the Hamms when they purchased the Coach in 1991. Indeed, even if the Hamms were deemed the "seller" of the Coach, the Gordons would not benefit. The Hamms were not in the business of dealing in motor coaches; consequently, the Gordons would not be buyers in the ordinary course if they purchased the Coach directly from the Hamms. ${ }^{294}$

Thus, the Gordons purchased the motor home subject to a security interest created by someone prior to their seller in the chain of title. Having found that the security interest created by someone other than the Gordons continued in the motor home, the court concluded that the Gordons had to satisfy Deere's security interest. Although "this case is particularly difficult factually . . . because the four parties to this lawsuit are not morally blameworthy," the court observed, "someone must suffer the loss occasioned by the absent thief." 295 That someone was the BIOCOB (e.g., the Gordons). Other cases produced similar results under former Article 9, often involving the sales of used motor vehicles ${ }^{296}$ or boats. ${ }^{297}$

The "his seller" rule under former Article 9 did not enjoy universal support. ${ }^{298}$ Most critics seemed to view the rule as unfair for any number of selfevident reasons: the secured party is usually in the better position to protect itself; the buyer is never going to be able to learn of the security interest of a person so

294 Id. at 633-34.

295 Id. at 635.

296 See Bank One Texas, N.A. v. Arcadia Fin. Ltd., 219 F.3d 494 (5th Cir. 2000), reh'g denied, 234 F.3d 708 (5th Cir. 2000) (holding that sales of nine used vehicles "out of trust" were subject to a prior security interest); In re Sunrise R.V. Inc., 105 B.R. 587, 591 (Bankr. E.D. Cal. 1989):

[T] he [Uniform] Commercial Code will not generally insulate a good faith purchaser of a used vehicle from the claim of a lienholder whose lien on said vehicle was never satisfied due to the default of an insolvent dealer .... Because [the dealership] did not 'create' the security agreement ... [the prior lienholder's] interest will not be affected by the mechanics of section 9-307(1).

Id.

297 Sec. Pac. Nat'l Bank v. Goodman, 100 Cal. Rptr. 763 (Cal. Ct. App. 1972).

298 Indeed, it was often heartily criticized. See, e.g., Robert Dugan, Buyer-Secured Party Conflicts Under Section 9-307(l) of the Uniform Commercial Code, 46 U. COLO. L. REV. 333 (1975); Charles L. Knapp, Protecting the Buyer of Previously Encumbered Goods: Another Plea for Revision of U.C.C. Section 9-307(1), 15 ARIz. L. REV. 861 (1973); Linda J. Peltier, Buyers of Used Goods and the Problem of Hidden Security Interests: A New Proposal to Modify Section 9-307 of the Uniform Commercial Code, 36 HASTINGS L.J. 215 (1984); David H. Vernon, Priorities, the Uniform Commercial Code and Consumer Financing, 4 B.C. INDUS. \& COM. L. REV. 531 (1963). 
far back in the chain; it is economically inefficient and perhaps morally repugnant to place the loss with the bona fide purchaser, and so on. Given the reluctance of courts to enforce what they often characterize as a harsh result, 299 it is not surprising that the rule has few cheerleaders.

The best arguments in support of the rule derive from agency law. William Lawrence has argued that a secured party should benefit from the "his seller" rule because the secured party has given the debtor "apparent authority" to make certain dispositions of collateral. The "created by his seller" rule of former section 9-307(1) (and presumably the gender-neutral versions in the Revision) are, according to Lawrence, "supported by a sound, legitimate policy." 300 This policy is that the secured party clothes the debtor with the "apparent authority" to sell to a BIOCOB, but not to anyone else. ${ }^{301}$ The debtor's non-ordinary course sales are, in commercial vernacular, sales "out of trust," meaning that when the debtor has done something untoward with the collateral-engaged in an unauthorized bulk sale, for example-Article 9's policy should protect the secured party because the debtor has acted without "authority." On this theory, the U.C.C. appears to imagine that legitimate commerce will involve only long daisy-chains of BIOCOBs, each conferring discharge of security interests on the next. 302

There are, however, some problems with this analysis. First, the source of the agency relationship is unclear. Although some have argued that the U.C.C. was "superimposed ... over existing principles of law and equity,"303 we do not typically think of the debtor as the secured party's agent (although principles of

299 In addition to the Hamm case, other examples of the "we're-sorry-but-the-statutemade-us-do-it" language include: Martin Bros. Implement Co. v. Diepholz, 440 N.E.2d 320 , 325 (IIl. App. Ct. 1982) ("We recognize that the result which flows from this construction of the statute may seem unjust. .. However, this is consistent with the general rule set forth in the Code."); Exchange Bank v. Jarrett, 588 P.2d 1006, 1009 (Mont. 1979) ("This court recognizes that this is a harsh result, since the purchaser ... had no means to learn ... that the property he purchased was subject to a security interest.... Since we are bound by enacted laws ... no other course is open to us here."); General Motors Acceptance Corp. v. Troville, 6 U.C.C. Rep. Serv. (CBC) 409, 413 (Mass. App. Ct. Jan. 27, 1969) ("[I]f a hardship results from our interpretation, it is for the Legislature to remove it.").

300 Lawrence, supra note 90 , at 77 .

${ }^{301}$ Id. at 87 ("[T] he secured party has clothed the debtor with the indicia of apparent authority to sell the goods.").

302 Id. at 88 ("Buyers in ordinary course of business have . . purchased in established channels of trade where their expectations of legitimate sales transactions are highest."). Of course the same might be said of the second generation BIOCOB or any non-BIOCOB purchaser in good faith and without notice. They, too, may have purchased in established channels of trade, with similarly high expectations about the legitimacy of the transaction.

${ }^{303}$ Sarah Howard Jenkins, Preemption \& Supplementation Under Revised 1-103: The Role of Common Law and Equity in the New U.C.C., 54 SMU L. REv. 495, 505 (2001). 
agency may "supplement" Article 9 under section 1-103). Indeed, with the repeal of the Uniform Trust Receipts Act, the rhetoric (if not the fact) of fiduciary duty in the secured lending context was largely abandoned. ${ }^{304}$ It is thus curious that, while Professor Lawrence sketches the contours of agency thoughtfully, he fails to explain why any of these principles apply to a contractual secured lending relationship. Lawrence concedes that "[a] debtor and a secured party generally do not stand in an agent-principal relationship," but then argues that "agency law principles are consistent with the "created by his seller' limitation."305

Moreover, it is not clear what policy supports placing the loss with the ordinary course buyer. Usually, it will be more difficult and costly for $B / L^{\infty}$ to discover the remote and prior security interest of SP. Although SP's efforts to police D's use of collateral will not be costless (and may not always be effective), it will usually be cheaper (and more effective) to place this cost (and risk of loss) on SP than on $B / L^{\infty} \cdot 306$ If, for example, encumbered data have been disseminated to scores or hundreds of parties, several generations beyond the original debtor (i.e., to $B / L^{\infty}$ ) how would any of these purchasers determine the existence of the security interest?

Secured parties, by contrast, typically monitor their debtors' activities on a fairly frequent basis, and tend to have expertise in that regard. They can and should know what their debtors are doing with collateral. Data will often be "forward" traceable, in the sense that there will be a trail of transmission records from the computers of $\mathrm{D}$ to $\mathrm{B} / \mathrm{L}^{1}$ to $\mathrm{B} / \mathrm{L}^{2}$, and so on. Yet, there will be no selfevident (or even readily constructed) reverse trail. The $B / L^{\infty} s$ of the world, in other words, will have little capacity to learn of prior, remote security interests. Yet unlike the negotiable instruments model, these good faith purchasers would be saddled with costs they cannot readily discover when the transaction is anticipated or consummated. ${ }^{307}$

304 It continues to surface in the context of proceeds, as discussed in Part VI.A.2, infra.

305 Lawrence, supra note 90 , at 83 (citations omitted). Consistency is not necessarily a policy justification, especially given the harshness of certain applications of the "his seller" rule.

306 Where, as in the Hamm case, the security interest is noted on the certificate of title, the result probably should be different. If the buyer acquires the collateral with actual or constructive knowledge of the security interest, it is difficult to see how they should have bona fide purchaser (BIOCOB) status. See Gordon v. Hamm, 74 Cal. Rprt. 2d 631, 632 (Cal Ct. App. 1998).

307 See Robert Charles Clark, Abstract Rights versus Paper Rights under Article 9 of the Uniform Commercial Code, 84 YALE L.J. 445, 467 (1975) (explaining that holders in due course will take free of proceeds security interest in accounts converted to negotiable instrument because "it is more feasible for a bank entering into a general accounts receivable financing agreement with a dealer to write all the account debtors and tell them not to give the debtor a note evidencing their account obligation"). While it may not be feasible for SP to enter into similar agreements with all of D's potential purchasers or licensees, it may, as discussed in Part 
Nevertheless, the drafters of revised Article 9 appear unconcerned about problems posed by the "his seller" rule. The drafting committee for revised Article 9 apparently asked itself in 1996 whether the "his seller" rule should be revised or eliminated..$^{308}$ The consensus was that the current text "is satisfactory." 309 As Professor Nowka has observed, "this brief reference indicates the drafters were cognizant of the effect of [the] 'his seller' [rule] on a buyer of pre-encumbered goods." 310

Although revised Article 9 retains the "his seller" language (in gender neutral form), it should nevertheless protect remote purchasers of goods that are BIOCOBs. This is because the Rule of Continuity is the subject of an important exception where collateral is goods--U.C.C. section 2-403(2). Section 2-403(2) provides that the merchant who sells goods entrusted to him or her has the "power to transfer all rights of the entruster [read: secured party] to a buyer in ordinary course of business." 311 "Entrusting" is defined in section 2-403(3) to "include[] any delivery and acquiescence in retention of possession regardless of any condition expressed between the parties." 312 Taken literally, this should mean that any time a secured party knows that a debtor is in possession of collateral and "acquiesces" in the debtor's possession, there has been an entrusting. The official comment to section $2-403$ seems to contemplate just this result:

The many particular situations in which a buyer in ordinary course of business from a dealer has been protected against reservation of property or other hidden interest are gathered ... into a single principle protecting persons who buy in ordinary course out of inventory. Consignors have no reason to complain, nor have lenders who hold a security interest in the inventory, since the very purpose of goods in inventory is to be tumed into cash by sale. ${ }^{313}$

Thus, if the Hamm case arose today, the result might be different. If Deere Credit, the secured party, knew that the Hamms had sold the motor home to Sunset and took no action to recover it, there would be a strong argument in favor of the Gordons that Deere "acquiesced" in Sunset's possession of the collateral. This acquiescence, the argument would go, would be an "entrusting" which

VII.C below, be possible to "mark" information assets such that the security interest is disclosed in the asset itself.

308 Alvin C. Harrell, U.C.C. Article 9 Drafting Committee Considers October 1996 Draft, 51 CONSUMER FIN. L.Q. REP. 54, 60 (1997).

${ }^{309}$ Id.

${ }^{310}$ Richard H. Nowka, Section 9-320(a) of Revised Article and the Buyer in Ordinary Course of Pre-Encumbered Goods: Something Old and Something New, 38 BRANDEIS L.J. 9 , $26(2000)$.

311 U.C.C. $\$ 2-403(2)(2001)$.

${ }^{312}$ Id. \& 2-403(3) (2001).

${ }^{313} I d$. $\$ 2-403 \mathrm{cmt} .2$ (2001) (emphasis added). 
would empower Sunset to confer clean title to the motor home on the Gordons, assuming they were otherwise BIOCOBs. ${ }^{314}$

A similar kind of "acquiescence" could not occur with respect to information assets, both because the "his seller" rule remains alive and well for intangibles, and because there is no statutory equivalent to "entrusting" for this species of collateral. Under section 9-321, a "licensee in ordinary course of business takes its rights under a nonexclusive license free of a security interest in a general intangible created by the licensor, even if the security interest is perfected and the licensee knows of its existence." 315 And, unlike buyers of goods, section 2403(2)'s entrusting rules do not apply to general intangibles. The "his seller (licensor)" rules would therefore remain in full force.

The generation-skipping nature of the "his seller" rule would seem to have powerful implications for the negotiability of information. Because data move so rapidly from computer to computer-and are usually forward traceable-it is easy to imagine a secured party asserting rights not only against its debtor, but against those who acquire data from the debtor. As with data, bioinformation assets would seem to present similar problems. As suggested by the Edwards case discussed above, bioinformation from encumbered animals should be subject to the original security interest or a proceeds security interest. If a bioinformation company like Celera acquired a cell line from a farmer's cow that was subject to a security interest, and then obtained a patent on the cell line, and then licensed the patent in the ordinary course of business to pharmaceutical companies, would the licensees take subject to the security interest? They should because Celera did not create the security interest-the farmer who owned the cow did.

In short, although the CIPs Rules attempt to promote the negotiation of collateral under certain circumstances, they will restrain negotiation (and therefore commerce) in perhaps surprising ways when information assets are collateral.

\section{Three Arguments AgAINST ARTICLE 9 REMOTE CONTROL}

The picture painted so far suggests that Article 9 remote control is a bad thing, as it will permit secured parties to exert rights against assets held by third parties with whom they did not bargain and who were otherwise bona fide purchasers of the information assets in question. This is a somewhat vague claim, rooted in an as-yet undisclosed bias for a certain kind of free negotiability.

314 Note that the purchasers (the Gordons) might not have qualified for BIOCOB status if they knew (or had reason to know) that Deere Credit had an unsatisfied security interest in the motor home. As noted above, a BIOCOB must be one who buys in "good faith." $\$ 1-201$ (9) (2001). The Gordons might not have purchased in "good faith" if, from the certificate of title, they knew (or should have known) of Deere Credit's continuing interest in the motor home.

315 \& 9-321(b) (2001) (emphasis added). 
Before discussing how we may arrive at that negotiability for information assets, I offer below three arguments rooted in history and theory against the remote control that revised Article 9 gives to secured parties. I argue first that historically a secured party could pursue collateral in the hands of an innocent purchaser (a BFP) only if the debtor had engaged in some form of wrongdoing. Article 9 ignores that important equitable constraint on the secured party's remedy.

Second, I argue that the theoretical arguments most commonly used to support the current Article 9 regime generally cannot justify the CIPs Rules. These arguments include the claims that full priority for secured parties is "efficient," produces greater credit availability, and is rooted in widely accepted notions of property and contract. These claims may (or may not) be accurate as to the debtor, the secured party, and unsecured creditors of the debtor (in its immediate community). They are not accurate, however, as applied to remote buyers or licensees $\left(\mathrm{B} / \mathrm{L}^{\infty}\right)$.

Finally, I set the CIPs Rules in the context of contemporary approaches to property theory. I argue that the CIPs Rules applied to information assets may function like an "anticommons," a profusion of rights that impairs development and leads to inefficient uses of capital and resources. These modern approaches to property draw into question the merits of the CIPs Rules as applied to remote parties.

\section{A. History of the CIPs Rules}

The CIPs Rules, and their effect on the rights of third parties, did not spring into existence with the enactment of the Uniform Commercial Code. Both the continuity of interest rules and the proceeds rules appear to derive from equitable and statutory remedies that, as to remote parties, required a showing of wrongdoing by the original debtor (D), its purchaser $\left(\mathrm{B} / \mathrm{L}^{1}\right)$, or both, and that created a defense if the secured party "entrusted" collateral to the debtor. Unlike their common law and statutory precursors, however, the CIPs Rules no longer require SP to show any inequitable behavior by $\mathrm{D}$ or $\mathrm{B} / \mathrm{L}$. Moreover, while "entrusting" remains a defense if the collateral is goods, there is no comparable cutoff for general intangibles. The CIPs Rules therefore apply to information assets with little regard to the equities of any given disposition.

\section{Continuity of Interest Rules}

Agency law would appear to provide the equitable locus of the Rule of Continuity. ${ }^{316}$ In common law precursors to the modern secured transaction,

316 The Rule of Continuity is discussed in Part V.A.2, supra. 
"title" to collateral was often in SP, not D. ${ }^{317}$ The debtor was said to have "sold" the collateral to SP from whom D repurchased it by repayment of the loan. Until D fully repaid the loan, D was viewed at common law as SP's trustee. If, before satisfying the loan and without SP's authority, D sold the collateral, the sale would violate D's duty (as trustee) to SP. Although cases were not uniform, courts frequently held that the purchasers of collateral from the "faithless" debtor assumed D's obligations as trustee for SP. ${ }^{318}$ In this way, D's duties (if not SP's property interest in the collateral) continued after the collateral left D's hands.

The early uniform acts on secured transactions (or their transactional forebears) seem to have carried this approach forward, at least in the context of the continuity of interest rules. The Uniform Trust Receipts Act (UTRA) and the Uniform Conditional Sales Act (UCSA) both gave comparatively broad protection to BFPs. UTRA, for example, provided as follows:

Where the trustee (the debtor), under the trust receipt transaction, has liberty of sale and sells to a buyer in the ordinary course of trade ... whether or not filing has taken place, such buyer takes free of the entruster's security interest in the goods so sold, and no filing shall constitute notice of the entruster's security interest to such a buyer. 319

UCSA contained a similar provision:

When goods are delivered under a conditional sale contract and the seller expressly or impliedly consents that the buyer may resell them prior to performance of the condition, the reservation of property shall be void against purchasers from the buyer for value in the ordinary course of business, and as to them the buyer shall be deemed the owner of the goods, even though the contract or a copy thereof shall be filed according to the provisions of this act. ${ }^{320}$

This, according to the Commissioners of Uniform Laws, meant that the fact "[t]hat the goods have been put into the retailer's stock with the consent of the wholesaler [the secured party] is conclusive evidence that they are there for sale and that the retailer has title or the right to convey." 321

The nexus between agency principles and continuity of interest seems clear at this stage. The references to "liberty of sale" and "implied consent" strongly suggest a permissible scope of conduct by a debtor, and a correlative range of

317 See, e.g., Mershon v. Wheeler, 45 N.W. 95 (Wis. 1887).

318 See, e.g., Witczinski v. Everman, 51 Miss. 841 (1876) (holding that purchaser of mortgaged property is trustee in invitum of it or its proceeds, and liable to account to the mortgagee).

319 UNIF. TRUST RECEIPTS ACT $\$$ 9(2)(a), 9C U.L.A. 255 (1957).

320 UnIF. CONDITIONAL SALES ACT $\$ 9,2$ A U.L.A. 111 (1924).

321 UNIF. CONDITIONAL SALES ACT § 9, 2 U.L.A. 16 (1922). 
forbidden behavior. If, as Professor Lawrence suggests, the debtor acted without apparent authority, it may have done so without "liberty of sale" or "implied consent."322 Thus, although not explicit, the security interest would have continued (at least as to the first purchaser) as a remedy for breach of the agency relationship. Selling out of inventory, however, was strong, if not conclusive, evidence of authority to sell.

The Rule of Continuity first took its modern form in section 13(1), Article 7 of Tentative Draft No. 1 of the U.C.C. ${ }^{323}$ That section provided that "[a] good faith buyer of goods or documents in ordinary course of business takes free of an inventory lien even though there has been due filing and even though such buyer has knowledge of the lien or the financing statement." 324 At this stage in development, the continuity of interest rule contained nothing like the "his seller" rule that appears in revised sections $9-320 \& 321 .^{325}$

The "his seller" limit appears to emanate from the 1954-56 New York State Law Revision Commission's study of the 1952 Official Draft of the U.C.C. ${ }^{326}$ The Commission's report asked,

If the debtor [D] having possession or control of collateral fraudulently sells it or subjects it to a claim of a person who is not a buyer in ordinary course $\left[\mathrm{B} / \mathrm{L}^{1}\right]$, but is a person engaged in the business of selling goods of that kind, is the security interest cut off by a sale by that person $\left[\mathrm{B} / \mathrm{L}^{1}\right]$ to a buyer in ordinary course $\left[\mathrm{B} / \mathrm{L}^{2}\right] ?^{327}$

Although the Commission offered no clear answer, the question appears to have introduced the possibility that a downstream, good faith purchaser $\left(B / \mathrm{L}^{2}\right)$ might take subject to a security interest created more than one generation prior to the transaction that created $\mathrm{B} / \mathrm{L}^{2}$ 's interest, notwithstanding the absence of any bad behavior by $\mathrm{B} / \mathrm{L}^{1}$ or $\mathrm{B} / \mathrm{L}^{2}$. lending)

322 See Lawrence, supra note 90 , at $83-88$ (discussing basic attributes of agency law in

323 See U.C.C. \$ 9-307 cmt. 2 (Official Draft 1952); U.C.C. \$ 7-13 cmt. 1 (Tentative Draft No. 1, 1948), reprinted in 15 UNIFORM COMMERCIAL CODE DRAFTS 254 (Elizabeth Kelly ed., 1984) [hereinafter "U.C.C. DRAFTS"] ("The theory is that when the goods are inventory ... the secured party contemplates that his debtor will make sales, and so the debtor has effective power to do so, even though his buyers know the goods they buy were subject to the security interest.").

$324 \S 7-13(1)$ (Tentative Draft No. 1, 1948), reprinted in 4 U.C.C. DRAFTS, supra note 323 , at 278.

325 See Nowka, supra note 310 , at 14 ("It is apparent that there was no "his seller"-type requirement in section $13(1)$.").

326 Id. at 21 (citing 1 LAW REVIEW COMM'N, STUDY OF THE U.C.C. 242 (1955)).

327 Id. at 22 (citing 1 LAW REVIEW COMM'N, STUDY OF THE U.C.C. 243 (1955)). 
In 1956, the Editorial Board of the Uniform Commercial Code answered the question, concluding that the $\mathrm{BIOCOB}\left(\mathrm{B} / \mathrm{L}^{2}\right)$ could take free of a security interest, but only if it was created by "his seller" $\left(\mathrm{B} / \mathrm{L}^{1}\right) .{ }^{328}$ This, of course, created the natural inference that a security interest created by someone other than B/L'2's seller-for example, D-would survive. ${ }^{329}$

Although the meaning of the "his seller" addition was not explained at the time, ${ }^{330}$ it may have been intended to mesh with the entrusting rules of U.C.C. section 2-403(2), which provides that "any entrusting of possession of goods to a merchant who deals in goods of that kind gives him [sic] power to transfer all rights of the entruster to a buyer in ordinary course of business." 331 The New York Commission, for example, suggested that the "his seller" provision "should make it clear that 'entrusting' of the goods to the seller [D], by the person whose security interest is cut off, is the controlling factor, and should perhaps indicate specifically whether an entrusting by the debtor to a third party $\left[\mathrm{B} / \mathrm{L}^{1}\right]$, with the consent of the secured party, is sufficient to allow the third party's sale to a buyer in ordinary course $\left[\mathrm{B} / \mathrm{L}^{2}\right]$ to cut off the security interest." 332

Indeed, "entrustment" by SP appears to have been central to determining who, as between SP and a downstream good faith purchaser from a faithless D (e.g., $B / L^{\infty}$ ), should bear the loss. If SP "entrusted" D with collateral, SP often bore the risk that $D$ might dispose of the collateral against SP's wishes. ${ }^{333}$ The problem for SPs, however, is that without too much exaggeration, all nonpossessory security interests are a form of "entrusting." We would never imagine today that merely permitting D to use encumbered equipment, or to possess encumbered inventory that it sold not in ordinary course, meant that SP had "entrusted" D with the collateral such that it waived its rights in the collateral.

Having displaced the common law, as well as UTRA and UCSA, it is less than clear that the U.C.C. continues to view the debtor (or a buyer from the debtor) as a fiduciary for the secured party. The U.C.C. arguably swept away

328 See U.C.C. \$ 9-307 (1957), reprinted in 18 U.C.C. DRAFTS, supra note 323, at 566.

329 Peltier, supra note 298 , at 215.

330 The official comments fail to explain what the Editorial Board was attempting to accomplish by adding the "his seller" language. The comment simply explains that "[t]he former opening language has been omitted because the definition of "buyer in ordinary course of business' limits subsection (1) to inventory cases. The other changes are for clarification." U.C.C. $\$ 9-307$ recommendations of the Editorial Board (1956), reprinted in 18 U.C.C. DRAFTS, supra note 323 , at 308.

331 U.C.C. $\$ 2-403(2)(2001)$. The "entrustment" rules of U.C.C. section 2-403(2) are discussed in Part V.B.3, supra.

332 Nowka, supra note 310, at 23 (citing LAW REVIEW COMM'N, REPORT RELATING TO THE UNIFORM COMMERCIAL CODE 67 (1956)).

333 See, e.g., Scollans v. Rollins, 60 N.E. 983 (Mass. 1901) (discussing rule in context of "entrusted" securities as collateral). 
those duties when it repealed the many different security devices in use prior to the early 1950s. True, U.C.C. section 1-103 preserves "principles of law and equity" to the extent not "displaced by the particular provisions" of the U.C.C. ${ }^{334}$ And we sometimes refer to defaulting debtors as selling "out of trust." But we do not generally think of the debtor as fiduciary for the secured party. ${ }^{335}$ Indeed, by eliminating fiduciary concepts, Article 9's continuity of interest rules leave debtors (and those who purchase or license from them) burdened like a trustee without any of the benefits typically associated with such a relationship. Taking for value, in good faith, without notice of prior claims or interests, for example, would not be a defense under the U.C.C., except as expressly provided in the cutoffs.

\section{Proceeds}

Like the continuity of interest rules, debtor misbehavior once played a role in giving the secured party the ability to pursue proceeds. These rules have, however, long since expanded to a series of default rules in which innocent debtors-and, more importantly, third parties-will acquire proceeds subject to a prior security interest of which they probably have no knowledge.

Professor Barnes has identified the transformation of proceeds rules from creatures of equity to baseline entitlements of the secured party. ${ }^{336}$ Before enactment of the U.C.C., equity was the locus for deciding the reach of a proceeds security interest in property. A secured party could trace a proceeds security interest in two general circumstances: Either the debtor misbehaved (committed fraud and/or breached a fiduciary duty) or the third party in possession of the property had a "lesser" equity in the property. ${ }^{337}$ As with the continuity of interest rules, early case law on proceeds drew heavily from trust law to determine the reach of the proceeds security interest. ${ }^{338}$

334 See \& 1-103 (2001).

335 Lawrence, supra note 90, at 83 ("A debtor and a secured party generally do not stand in an agent-principal relationship.").

336 Richard L. Barnes, Tracing Commingled Proceeds: The Metamorphosis of Equity Principles into U.C.C. Doctrine, 51 U. PTTT. L. REV. 281 (1990).

337 Id. at 294. As to the second, the question was whether the contest involved "an innocent party against the wrongdoer, or . . . two innocents each seeking the funds as his or her own?" Id.

${ }^{338}$ Id. at 305 ("[T] he case law inference of a right to trace rests wholly on the analogy drawn in the early cases to trust law."). Professor Bames argues that the analogy is "thin, in part because of the dearth of cases in which constructive trusts are imposed." Id. (citations omitted). "There are," Barnes observes, "a number of pre-code cases in which a constructive trust was applied in a commercial setting. Yet they provide little support to the notion of a tracing rule based wholly on commercial principles." Id. By "commercial principles," I take it Professor Barnes means "rules other than those rooted in equity." Id. 
Even before enactment of the U.C.C., for example, proceeds problems arose under the Uniform Trust Receipts Act in which inventory financiers sought priority over purchasers of chattel paper representing the proceeds of the financed inventory. The problem was "extensively litigated ... with divergent results."339 As originally promulgated in 1952, Article 9 provided that "proceeds" included whatever was "received by the debtor" when the debtor sold, exchanged, collected or otherwise disposed of collateral or proceeds. 340 Proceeds also included the account arising when the right to payment was earned under a contract. ${ }^{341}$

Notwithstanding its seeming breadth-“including" implies no obvious limit-courts construed this definition of proceeds narrowly, to exclude insurance payable upon the loss or destruction of original collateral. ${ }^{342}$ These courts typically declined to recognize the proceeds security interest in insurance proceeds because such a security interest should arise only when the debtor actually passed "title" to the collateral. 343 Since a debtor did not pass title to damaged collateral, the reasoning went, no disposition occurred and therefore no proceeds security interest arose. ${ }^{344}$

The first reported U.C.C. case to consider tracing the security interest in commingled cash proceeds was Universal C.I.T. Credit Corp. v. Farmers Bank $^{345}$ There, the secured party had a perfected security interest in the debtor's inventory of automobiles. ${ }^{346}$ The debtor sold some cars and deposited the funds

3391 GILMORE, supra note 75, at 720 (citing Robert H. Skilton, Cars for Sale, 1957 WIS. L. REV. 352,412 ).

340 U.C.C. $\$ 9-306$ (1) (1952), reprinted in 15 U.C.C. DRAFTS, supra note 323, at 246.

341 \$ 9-306(3) (1952), reprinted in 15 U.C.C. DRAFTS, supra note 323, at 247.

342 See, e.g., Sanchez v. United States, 696 F.2d 213, 215-16 (2d Cir. 1982); In re Whitacre, 21 U.C.C. Rep. Serv. (CBC) 1169, 1174-75 (Bankr. S.D. Ohio Sept. 23, 1976); In re Parks, 19 U.C.C. Rep. Serv. (CBC) 334, 334-35 (Bankr. E.D. Tenn. Mar. 5, 1976); In re Waltman, 18 U.C.C. Rep. Serv. (CBC) 576, 579 (Bankr. S.D. Ala. Nov. 12, 1975); In re Hix, 9 U.C.C. Rep. Serv. (CBC) 925, 927-28 (Bankr. S.D. Ohio Dec. 23, 1969); In re Levine, 6 U.C.C. Rep. Serv. (CBC) 238, 241 (Bankr. D. Conn. Jan. 17, 1969); White v. Household Fin. Corp., 302 N.E.2d 828, 836 n.9 (Ind. Ct. App. 1973); Quigley v. Caron, 247 A.2d 94, 95-96 (Me. 1968); Third Nat'l Bank v. Continental Ins. Co., 446 N.E.2d 380, 382 (Mass. 1983); In re Boyd, 658 P.2d 470, 471-74 (Okla. 1983); Universal C.I.T. Credit Corp. v. Prudential Inv. Corp., 222 A.2d 571, 574-75 (R.I. 1966).

343 Universal C.I.T. Credit Corp. v. Prudential Inv. Corp., 222 A.2d 571, 574-75 (R.I. 1966); see also Freyermuth, supra note 271, at 655-58.

344 See Freyermuth, supra note 271, at 656 ('Under the 1962 version of Section 9-306(1), the vast majority of courts addressing [the insurance-proceeds issue] concluded that since damaged collateral was not disposed of under Section 9-306(1), insurance moneys were not proceeds of the damaged collateral.").

345358 F. Supp. 317 (E.D. Mo. 1973).

346 Id. at 323 
(the proceeds) in a general checking account where they became commingled with non-proceeds. ${ }^{347}$ The debtor's bank set off against the account, and the secured party, citing the U.C.C.'s proceeds and continuity of interest rules, argued that its interest in the account was superior to the bank's. ${ }^{348}$

In order to determine whether the secured party had a security interest in the commingled funds, the court had to determine whether they were "identifiable." To determine a standard of identifiability, the court imported the constructive trust law of the controlling jurisdiction (Missouri). ${ }^{349}$ Citing a divorce case, ${ }^{350}$ the court announced what has come to be the now-commonplace "lowest intermediate balance test," by which the debtor is presumed to have first expended its own (non-proceeds) funds, leaving behind the funds of the secured party (that is, funds subject to the proceeds security interest). ${ }^{351}$

Yet even here, "equity" played a role. A significant factor in the court's ruling appears to be the fact that the debtor committed what the court viewed as "fraud" in disposing of the collateral..$^{352}$ The debtor, George W. Ryan, d/b/a RyanChevrolet and Olds Co., had entered into a floor plan with C.I.T. (the secured party) that required him to remit payments to C.I.T. as and when Ryan sold cars. ${ }^{353}$ The payments were from Ryan's checking account with defendant, Farmers Bank of Portageville.

After C.I.T. decided to terminate Ryan's financing, Ryan told a Farmers Bank officer that he wanted to make sure that the bank would get paid on a note it was owed despite that he was going out of business. ${ }^{354}$ Thus, Ryan and the bank officer agreed that the bank would debit Ryan's account, knowing that this would leave insufficient funds to cover checks already drawn by Ryan and made payable to C.I.T., but ensuring that the bank would be paid. ${ }^{355}$

C.I.T. claimed that the bank was not entitled to offset Ryan's account as it contained proceeds of the cars C.I.T. financed. 356 The bank, by contrast, argued that the proceeds in Ryan's account had become commingled with other funds of Ryan's, and so were not identifiable proceeds under former section 9-306(2). ${ }^{357}$

${ }^{347}$ Id.

348 Id. at 323 .

349 Id. at 324 .

350 Id. at 324 (citing Perry v. Perry, 484 S.W.2d 257 (Mo. 1972)).

351 Universal C.I.T. Credit Corp. v. Farmers Bank, 358 F. Supp. 317, 325-26 (E.D. Mo. 1973).

352 Id. at 324 .

353 Id. at 320 .

354 Id. at 320 ('“[L]et C.I.T. be last-they put me out of business."').

355 Id.

356 Id. at 323.

357 Universal C.I.T. Credit Corp. v. Farmers Bank, 358 F. Supp. 317, 323 (E.D. Mo. 1973). 
The court acknowledged that official comment 2(c) to former section 9-306 suggested that the secured party had little power to recover proceeds from the bank. That comment provided that:

Where cash proceeds are covered into the debtor's checking account and paid out in the operation of the debtor's business, recipients of the funds of course take free of any claim which the secured party may have in them as proceeds. The law of fraudulent conveyances would no doubt in appropriate cases support recovery of proceeds by a secured party from a transferee out of ordinary course or otherwise in collusion with the debtor to defraud the secured party. ${ }^{358}$

Here, the court reasoned, the bank's offset against Ryan's account was not in ordinary course and thus was probably a fraudulent conveyance. ${ }^{359}$ Among other things, the bank's officer knew that C.I.T. had revoked Ryan's financing, that Ryan had already written checks against the account that would be uncollectible by C.I.T., and that the bank's debit of the account occurred after the close of business but before the C.I.T. checks were likely to be presented for payment. 360 "These facts," the court concluded, "clearly show that the debit of Ryan's account was not in the ordinary course of business." 361

The court also reasoned that, under common law principles of set-off, the bank would have lacked the right to debit Ryan's account. "As a general rule," the court observed, "an account constituting a general deposit account is subject to the bank's right of set-off." 362 A bank would not, however, have a right of set-off when it had "sufficient knowledge of facts relating to the interests of others in the account as to put the bank on inquiry to ascertain the trust character of the account." 363 Knowledge of the "trust character" of an account could be shown by "indirect evidence" or by showing that the bank had inquiry notice of the trust character of the account. Here, the court concluded that the same basic facts that gave rise to the fraudulent conveyance claim also put the bank on inquiry notice "as to the possible trust character of all or part of the funds deposited in Ryan's account. ${ }^{364}$ The court thereafter went on to apply the lowest intermediate balance test to establish C.I.T.'s proceeds security interest.

${ }^{358}$ Id. at 324 (emphasis added) (quoting U.C.C. $\$ 9-306 \mathrm{cmt}$ 2(c) (1972)).

${ }^{359} \mathrm{Id}$.

360 Id.

361 Id.

362 Id. at 325 (citing First Nat'l Bank of Clinton v. Julian, 383 F.2d 329, 338 (8th Cir. 1967); Adelstein v. Jefferson Bank \& Trust Co., 377 S.W.2d 247, 251 (Mo. 1964)).

363 Universal C.I.T. Credit Corp. v. Farmers Bank, 358 F. Supp. 317, 325 (E.D. Mo. 1973) (quoting Northem Ins. Co. v. Traders Gate City Nat'l Bank, 186 S.W.2d 491, 497 (Mo. Ct. App. 1945)).

${ }^{364}$ Id. at 325 . 
The Farmers Bank case left some questions unanswered. First, the relationship between fraud and breach of duty is not clear. It may be, as the facts suggest, that the debtor and the bank colluded to commit fraud. It is not, however, clear that the debtor-much less the bank-had a fiduciary duty to C.I.T. Indeed, although the court used the Restatement of Trusts, Second, section 202 to determine how to trace under the "lowest intermediate balance rule" (LIBR), the court failed to explain the connection, if any, between fraud and breach of fiduciary duty on these facts.

Nor did the court connect the remedy to the wrongs of the debtor and the bank. There are many ways a court could "equitably" determine rights in commingled cash proceeds. Professor Gilmore unpopularly believed that a secured party that permitted the debtor to commingle cash proceeds lost its interest in any of the commingled corpus because commingled property could, by definition, no longer be "identifiable." 365 Only one court published an opinion taking this view. 366 Other ways to trace include "first-in, first-out" (FIFO), ${ }^{367}$ "last-in, first-out" (LIFO), ${ }^{368}$ or pro-rata approaches to trace proceeds. ${ }^{369}$

3651 GLMORE, supra note 75 , at 735-36.

366 Morrison Steel Co. v. Gurtman, 274 A.2d 306, 310 (N.J. Super. Ct. App. Div. 1971).

367 FIFO is an accounting method that treats the first goods purchased or produced as the first to be sold. In In re California Trade Technical Schools, Inc., 923 F.2d 641, 649-50 (9th Cir. 1991), the U.S. Court of Appeals for the Ninth Circuit applied a FIFO presumption in a preference challenge to avoid the deposit of some commingled funds. The court in Califomia Trade reasoned that the underlying purpose of the Bankruptcy Code's prohibition of "preferential" and "fraudulent" transfers was to discourage last minute transfers that were out of the ordinary course and/or not supported by an exchange of reasonably equivalent value. On this theory, the court viewed FIFO as producing the most fair result because it would presume that funds wrongfully transferred to an account at the eleventh hour remained there until all of the funds previously in the account were spent.

FIFO has been applied in other contexts as well. Two New York courts have used FIFO to distribute assets from a decedent's estate. Estate of Agioritis, 383 N.Y.S.2d 304 (N.Y. App. Div. 1976); Estate of Spinelli, 384 N.Y.S.2d 665 (N.Y. Sur. Ct. 1976). An Iowa court found, under either Iowa or Minnesota law, that FIFO could be used to determine the extent of a creditor's purchase money lien upon entering into a new loan transaction. In re Wilbert D. Hassebroek, 136 B.R. 527, 531 (Bankr. N.D. Iowa 1991) (citing JAMES J. WHITE \& ROBERT S. SUMMERS, UNIFORM COMMERCIAL CODE 333-34 (3d ed. 1987), for promoting FIFO method of allocating payments to debt); see also Harris J. Diamond, Note, Tracing Cash Proceeds Under Revised Article 9, 9 AM. BANKR. INST. L. REV. 385, 412-13 (2001).

${ }^{368}$ LIFO treats the last goods purchased or produced as the first to be sold. Under LIFO, a court would presume that the last money into the account was the first spent. See Chase Manhattan Bank, N.A. v. Traditional Invs. Corp., No. 92-Civ.2774(ss), 1995 WL 72410, at *3 (S.D.N.Y. Feb. 21, 1995) (applying LIFO where depositors were fraudulently induced into depositing funds such that depositors receive their money in inverse order of times of their respective payments into fund).

369 A pro-rata approach might take any of several forms. Pro-rata allocations typically occur in contests between more than one secured party, rather than in disputes between a 
Perhaps the strangest thing about the Farmers Bank case was the redundancy of the remedy. Not only did C.I.T. have a proceeds claim; it also had a fraudulent conveyance claim and a claim for wrongful setoff. What this really means is that C.I.T. did not need the proceeds claim. Either one or both of the fraudulent conveyance or wrongful setoff claims should have given C.I.T. a sufficient remedy. What, if anything, did the right to proceeds add? 370

Unfortunately, the Farmers Bank decision failed to provide explicit guidance on the role (if any) that debtor/purchaser misconduct might play in establishing rights in proceeds. The fact that the court used the U.C.C.'s proceeds rules in addition to other, existing remedies (which did require a showing of some such misconduct) suggests a developing indifference to the equities in determining the reach of a proceeds security interest. This was consistent with the trend among those responsible for revising Article 9, the Permanent Editorial Board (PEB). ${ }^{371}$

In 1972, the PEB established a Review Committee that undertook the first of several expansions of the definition of proceeds, all of which would separate the analysis of rights in proceeds from debtor/purchaser conduct. ${ }^{372}$ For purposes of this article, the most important expansion involved the continuity of proceeds security interests. The Review Committee observed that "[u]nder the existing 9306 the security interest in proceeds extends without limit through cash in the debtor's hand to repeated cycles of the debtor's business so long as the proceeds

secured party and a bankruptcy trustee (or lien creditor). Thus, in In re Halmar Distributors, Inc., 232 B.R. 18, 24-26 (Bankr. D. Mass. 1999), the court found a pro-rata approach to be a viable form of tracing where a purchase-money creditor sued to determine its competing rights against a bank that allegedly committed conversion. The court found the pro-rata approach to be "universally accepted in . . other jurisdictions." 232 B.R. at 26 (quoting Gen. Motors Acceptance Corp. v. Norstar Bank, N.A., 532 N.Y.S.2d 686 (N.Y. Sup. Ct. 1988)); see also In re Foster, 275 F.3d 924, 927-28 (10th Cir. 2001); Bombardier Capital, Inc. v. Key Bank of Me., 639 A.2d 1065, 1067 (Me. 1994) (recognizing that two secured creditors' interests required prorating account balance).

The pro-rata approach also has roots in English cases involving a breach of trust. See, e.g., In re British Red Cross Balkan Fund, 2 Ch. 419, 421 (1914) (permitting donors to Balkan War relief fund to share pro-rata according to the amount of their donation).

370 Today, Farmers Bank would likely come out differently, as a bank that was also a secured party would be said to have a security interest in the debtor's account perfected by "control." See U.C.C. \$ 9-104(a)(1) (2001) ("A secured party has control of a deposit account if "the secured party is the bank with which the deposit account is maintained."'). The controlperfected security interest will always have priority over a security interest in funds in the deposit account claimed as proceeds and perfected merely by filing a financing statement. U.C.C. \$ 9-327(1) (2001) ("A security interest held by a secured party having control of the deposit account ... has priority over a conflicting security interest [in the same account] held by a secured party that does not have control.").

371 The role of the PEB is explained in supra note 271.

372 See Gilmore, supra note 1, at 625. 
can be traced ...."373 Thus, the Committee observed, "a financing statement on automobiles could theoretically operate to perfect a security interest in an oil painting traded in for an automobile or bought with the cash proceeds thereof." 374 Rather than limiting the proceeds security interest in all cases, however, the Committee chose to "limit the claim to proceeds which have been acquired through cash proceeds to cases where the description of collateral in the financing statement indicates the types of property constituting these remote proceeds." 375 In other words, the proceeds security interest was more likely to survive when the proceeds were non-cash proceeds, than when they were cash proceeds. Since we have seen how readily information-which will usually not be cash-can become proceeds, this distinction has new importance and presents new challenges.

Despite the expansiveness of the 1972 amendments, lenders remained dissatisfied with the treatment of proceeds. Three classes of cases under the 1972 amendments prevented secured parties from reaching certain kinds of proceeds. First, a number of courts held that rents collected by the debtor on collateral that the debtor leased out were not proceeds. ${ }^{376}$ Second, non-liquidating dividends received by the debtor were not considered proceeds of the stock which was, itself, original collateral. ${ }^{377}$ Third, tort claims arising from damage to original collateral were not considered proceeds of the original collateral. ${ }^{378}$

${ }^{373}$ See 1972 Official Text Showing Changes Made in Former Text of Article 9, Secured Transactions, and of Related Sections and Reasons for Changes, in UNIFORM COMMERCIAL CODE 990 (West ed. 1999) (citing In re Platt, 3 U.C.C. Rep. Serv. (CBC) 275, 281 (E.D. Pa. 1966), aff'd, 257 F. Supp. 478 (E.D. Pa. 1966)).

374 Id.

375 Id. This problem was not necessarily new in the early 1970s. Professor Gilmore observed in 1965 that:

[A]part from a subordination agreement, no one can safely finance a dealer's used or secondhand inventory (to the extent that it consists of proceeds) if a financing statement, which claims proceeds (as, it may be assumed, all inventory financing statements do), is on file with respect to the dealer's new inventory.

1 GILMORE, supra note 75, at 733-34.

376 E.g., In re Corpus Christi Hotel Partners, 133 B.R. 850, 856 (Bankr. S.D. Tex. 1991); In re Keneco Fin. Group, 131 B.R. 90, 94 (Bankr. N.D. Ill. 1991); In re Inv. Hotel Props., 109 B.R. 990, 995-96 (Bankr. D. Colo. 1990); In re A.E.I. Corp., 11 B.R. 97, $100-02$ (Bankr. E.D. Pa. 1981); In re Cleary Bros. Constr. Co., 9 B.R. 40, 41 (Bankr. S.D. Fla. 1980). But see In re S. Equip. Sales Co., 24 B.R. 788, 794 (Bankr. D.N.J. 1982).

377 See In re Hastie, 2 F.3d 1042, 1045-46 (10th Cir. 1993). Liquidating dividends, by contrast, were considered proceeds of stock because there was no value left in the stock following liquidation. See Aycock v. Texas Comm. Bank, 127 B.R. 17, 18-19 (Bankr. S.D. Tex. 1991).

378 See, e.g., In re Boyd, 658 P.2d 470, 471-74 (Okla. 1983); Bank of N.Y. v. Margiotta, 416 N.Y.S.2d 493 (N.Y. Dist. Ct. 1979); Hoffman v. Snack, 2 U.C.C. Rep. Serv. (CBC) 862, 863 (Pa. C.P. 1964). This should not have been terribly troubling to lenders at the time. Prior to 
Recognizing these problems, the drafters of the PEB Report recommended in 1992 that Article 9 be revised to make clear that a proceeds security interest does arise in these three circumstances. ${ }^{379}$ The PEB Report further recommended making clear that the proceeds security interest continues in property even if the property was not "received by" the debtor. ${ }^{380}$ The thrust of these recommendations was to orient the definition of proceeds around "rights" arising with respect to collateral, and to continue those rights (for the benefit of the secured party) well beyond the boundaries of the debtor. The recommendations of the PEB Report are therefore part of the larger trend toward expanding the reach of the proceeds security interest.

The PEB Report recognized that courts had used two different theories to understand proceeds: the "exchange and replacement" theory and the "close association" theory. ${ }^{381}$ The "exchange and replacement" theory "contemplate[d] that proceeds will be received in place of and in substitution for the original collateral, which has been disposed of or reduced in value (such as by collections)." 382 Because the reported cases were "not uniform on" their treatment of collateral that was leased-sometimes the lease was proceeds (as an "other disposition") and sometimes it was not ${ }^{383}$-the PEB Report recommended that former section 9-306(1) "be clarified" to reflect the result in cases holding that a lease of collateral was, itself, proceeds of the original collateral. ${ }^{384}$ Recognizing that a license of intellectual property would function in some respects like a lease of goods, the PEB Report also recommended that the drafting committee for the Revision "consider whether to revise the definition of proceeds" to include royalties arising out of the debtor's license of general intangibles. ${ }^{385}$ The PEB

the revision, Article 9 did not apply "to a transfer in whole or in part of any claim arising out of tort." U.C.C. § 9-104(k) (1990); see also New England Mortgage Servs. Co. v. Petit, 590 A.2d 1054, 1055-56 (Me. 1991) (holding that a judgment creditor could not assert a lien upon any proceeds to be derived from the debtor's pending malpractice claim because Article 9 excludes tort claims from its scope).

379 PEB REPORT, supra note 271, at 106, 110-11. Even before the PEB Report was issued in December 1992, the PEB sought to protect proceeds security interests in lease payments arising from the debtor's rental of collateral. In PEB Commentary No. 9 (June 25, 1992), the PEB concluded that " $[w]$ here a debtor has granted to a secured party a security interest in goods and the debtor later leases those goods as lessor, the lease rentals will constitute proceeds of the secured party's collateral consisting of goods."

380 Id. at $106,112$.

381 Id. at $110-11$.

382 Id. at 110.

${ }^{383}$ See cases cited at supra note 376.

384 PEB REPORT, supra note 271, at 110.

385 Id. 
Report was, for reasons not explained, less certain on this point, viewing licensesas-proceeds as "perhaps less clear" than leases-as-proceeds. ${ }^{386}$

The PEB Report observed that "[a]nother way of characterizing what proceeds are or should be does not depend on the exchange [or replacement] concept," but instead viewed proceeds as "those things that are so necessarily and obviously associated with an interest in the original collateral that a security agreement and financing statement ought not to be required to mention them explicitly." 387 On this "close association" theory, if by virtue of the debtor's interest in the original collateral the debtor was "entitled" to other property, "a secured party should likewise be entitled to the [proceeds] property as collateral." 388 This theory of proceeds "would embrace all forms of distributions on account of securities, partnership interests, and other intangibles . . . that do not involve an "exchange.""389

Although the PEB Report recommended that former Article 9 be revised to embrace the close association theory of proceeds, 390 it also recognized that there should be some limit to proceeds. "At some point," the PEB Report observed in a footnote, "the acquisition of assets by a debtor ... will be too attenuated for those assets to be considered proceeds." 391 The PEB Report then gave several examples. Accounts receivable that arise either from the use of equipment by a construction company or from inventory fabricated by that equipment should not be considered proceeds, "even though the equipment depreciates as a result of its use ...."392 A case "closer to the margin" would involve vending machines that were collateral: "Has the equipment merely provided a service, or is the better analogy that of short-term rental?" The authors of the PEB Report were "inclined to leave such marginal cases to the courts." 393

Professor Freyermuth has criticized the PEB Report's approach to proceeds as being "result oriented" and confusing the attachment of a proceeds security interest with the continuity of that interest. ${ }^{394}$ According to Professor Freyermuth, the PEB Report assumed "the correct result-that the secured party in the construction contractor hypothetical should not have a continuing security interest against the contractor's accounts" and then tried to create a rule to fit that result,

386 Id.

387 ld. at 111 .

388 ld.

389 ld.

390 PEB REPORT, supra note 271, at 111.

391 Id. at n. 16.

392 Id.

393 Id.

394 Freyermuth, supra note 271 , at 700. 
namely that the accounts were not "proceeds."395 This, according to Professor Freyermuth, was senseless. Rather than choosing "the most apparent solution that achieves that result-treating the contractor's accounts as nonproceeds,"396 the PEB Report should have recognized that all such dispositions or uses of collateral would generate proceeds.

The proper limitation on proceeds, Professor Freyermuth argued, would be found not in the definition of proceeds but in the requirement that the proceeds be "identifiable" in order for the security interest to continue in them. All economic uses of collateral, according to Professor Freyermuth, would generate proceeds under one theory of proceeds or another, and it is overly formalistic to say otherwise. ${ }^{397}$ The proceeds security interest arising with respect to equipment should end in the accounts or inventory associated with the equipment but not the lease of it, according to Professor Freyermuth, because the lease is "identifiable." 398 The accounts receivable or inventory, by contrast, "cannot be identified precisely to the equipment." 399

Ultimately, Professor Freyermuth has argued that the proceeds security interest should reach as far as "legally protectible right[s] of use in the equipment itself." ${ }^{400}$ While it is not entirely clear what this means, ${ }^{401}$ it nevertheless appears

$$
\begin{aligned}
& 395 \text { Id. } \\
& 396 \text { Id. at } 701 . \\
& 397 \text { Id. } \\
& 398 \text { Id. } \\
& 399 \text { Id. at } 701-02
\end{aligned}
$$

While the accounts are proceeds of the equipment, at a minimum they are also proceeds of any materials the contractor used on the job and the contractor's labor and expertise. Since the accounts are not identifiable precisely to the equipment, the secured party's lien should not extend to the accounts under Section 9-306(2).

Id.

Of course, on this theory, commingled cash proceeds should also not be proceeds, since one could not, through accepted methods of tracing, "precisely" identify that portion of cash in a single account that constitutes proceeds as distinct from cash not subject to a proceeds security interest. Indeed, for this reason, as indicated in text at note 365, supra, Professor Gilmore believed that commingled cash proceeds were not subject to a security interest. 1 GILMORE, supra note $75, \S 27.4$, at $735-36$.

400 Freyermuth, supra note 271, at 704 .

401 Professor Freyermuth supports this position by suggesting that it would reflect "the expected ex ante bargain of the reasonable debtor and secured party," because "payments ... traceable only to the equipment, . . cannot [be] confuse[d] with other inputs over which the parties do not appear to have bargained in the security agreement." Id. at 705. If, however, the contractor uses the equipment to generate accounts on its own construction jobs, 
that the Revision takes a significant step in that direction. The proceeds security interest should attach to any right arising incident to the original collateral. It should reach, among other things, the customer data received by an Internet (or any other) retailer, licenses and sublicenses of intellectual property, and perhaps the organs grown with stem cells that are collateral. Patents should be proceeds of trade secrets, and derivative works should be proceeds of the original copyright. The infringement of any kind of intellectual property will also be proceeds of the original intellectual property collateral (e.g., a copyright or patent). Because there is no requirement that the debtor have possession or control of proceeds, the proceeds security interest will bloom like algae, racing from computer to computer, or petri dish to petri dish, always identifiable and, at least as a statutory matter, unstoppable except to the extent limited by the fairly ineffectual statutory cutoffs discussed above.

Although perhaps not surprising, it remains troubling that the rules on proceeds security interests, like the rules on the continuity of security interests, have become detached from their historical footing in the conduct of the debtor and/or the purchaser. Detaching the CIPs Rules from their equitable base may have been sensible in a world with relatively stable, slow-moving forms of collateral (i.e., goods). Although perhaps not stated so boldly in the commentary, the CIPs Rules save secured parties the trouble (and cost) of having to prove bad acts, intent, or any of the other (perhaps difficult or costly-to-establish) elements of the older causes of action. They also save secured parties the burden (and presumably cost) of having to negotiate for these rights in every security agreement.

Yet, no particularly good reason has ever been advanced in support of wholly detaching the CIPs Rules from their equitable roots. The absence of justification may have been tolerable with slower-moving collateral (goods) because problems of remote control arose fairly infrequently. Moreover, it was difficult, if not impossible, to "trace" collateral or proceeds more than several generations beyond the debtor. Therefore, the expectations of secured parties were likely so limited. Applying the continuity of interest rules to assets as mobile, mutable, and replicable as the information assets discussed so far, however, the response might be far different.

$[\mathrm{N}] \mathrm{o}$ reasonable person in the position of the secured party could expect its lien to continue against those accounts. The accounts do not flow solely from the equipment, but also from other inputs (labor, raw materials, etc.) over which the parties do not appear to have bargained. Thus, one cannot conclude that the parties would understand that those accounts would stand in place of the collateral. The parties' failure to anticipate and deal with the tracing problem, which they might have done by including accounts as part of the collateral, reflects their apparent understanding that the secured party should have no continuing lien upon the debtor's accounts.

Id. 


\section{B. The Full Priority Debate}

The history of the CIPs Rules suggests that they have become detached from their common law roots and apply mechanically without regard to the equities of any given disposition or transformation of collateral. This Part suggests that they are also inconsistent with the strongest normative argument advanced to support Article 9's full priority regime: The "base-line" rules of contract and property. While contract and property rules may justify the power to fully encumber assets for the benefit of secured parties, these rules appear curiously ineffective when marshalled for the benefit of remote buyers or licensees of encumbered information assets (i.e., $\mathrm{B} / \mathrm{L}^{\infty}$ ).

For over twenty years, commercial law academics have struggled to answer an important if basic question: Is full priority for secured parties a good thing?402 The debate in its more recent form has asked whether secured lending is "efficient." ${ }^{403}$ Efficiency in this context generally means either that full priority is

402 Symposium issues of the Cornell Law Review and the Virginia Law Review offer revealing glimpses into this debate. See Symposium, The Priority of Secured Debt, 82 CORNELL L. REv. 1279 (1997); Symposium, The Revision of Article 9 of the Uniform Commercial Code, 80 VA. L. REv. 1783 (1994).

403 The focus on "efficiency" is said to have begun when scholars applied the "Modigliani-Miller" hypothesis to secured financing. See Steven L. Schwarcz, The Easy Case for the Priority of Secured Claims in Bankruptcy, 47 DUKE L.J. 425, 429 (1997) (making the observation above) (citing Franco Modigliani \& Merton Miller, The Cost of Capital, Corporation Finance and the Theory of Investment, 48 AM. ECON. REV. 261, 268 (1958)). The Modigliani-Miller theory suggests that a firm's savings from one effort will have a correlative cost elsewhere, yielding no net gain in firm value. In this context, the theory would predict that, while secured creditors might charge lower rates of interest (reflecting reduced risk from recourse to collateral), unsecured creditors would raise their interest rates (reflecting increased risk from the loss of recourse to unencumbered property of the debtor). See Schwarcz, supra, at 429.

Other contributions to the efficiency literature include Barry E. Adler, An Equity-Agency Solution to the Banknuptcy-Priority Puzzle, 22 J. LEGAL STUD. 73 (1993); Richard L. Barnes, The Efficiency Justification for Secured Transactions: Foxes with Soxes and Other Fanciful Stuff, 42 U. KAN. L. REv. 13, 33 (1993); Lucian Arye Bebchuk \& Jesse M. Fried, The Uneasy Case for the Priority of Secured Claims in Bankruptcy, 105 YALE L.J. 857, 934 (1996) (arguing that the rule of full priority "causes excessive use of security interests, reduces the incentive of firms to take adequate precautions and choose appropriate investments, and distorts the monitoring arrangements chosen by firms and their creditors"); James W. Bowers, Whither What Hits the Fan?: Murphy's Law, Bankruptcy Theory, and the Elementary Economics of Loss Distribution, 26 GA. L. REv. 27, 64-67 (1991) (addressing the costs of security in light of debtor misbehavior); F.H. Buckley, The Bankruptcy Priority Puzzle, 72 VA. L. REV. 1393 (1986); David Gray Carlson, On the Efficiency of Secured Lending, 80 VA. L. REv. 2179 (1994); Jochen Drukarczyk, Secured Debt, Bankruptcy, and the Creditors' Bargain Model, 11 INT'L REV. L. \& ECON. 203 (1991); Claire A. Hill, Is Secured Debt Efficient?, 80 TEX. L. REV. 1117 (2002); Thomas H. Jackson \& Anthony T. Kronman, Secured Financing and Priority 
"Kaldor-Hicks" efficient or "Pareto optimal." A rule is "Kaldor-Hicks" efficient if losses (costs) imposed on "society" by the rule are more than offset by gains (benefits); the rule is "efficient" (and presumably "good") even if the winners do not compensate the losers. 404 "Pareto optimal" efficiency means that full priority would make the secured party and debtor better off, but no unsecured creditor worse off. 405 Therefore, it is considered "efficient" for a debtor to grant a security interest in $\$ 100$ of her $\$ 400$ worth of assets if the net result is that she will be able to pay off all of her $\$ 300$ in unsecured creditors in the ordinary course. The debtor will have "leveraged" $\$ 400$ worth of assets into $\$ 500$ and reduced her pool of obligations to $\$ 300$. Therefore, wealth has increased and risk has decreased. ${ }^{406}$

Among Creditors, 88 Y ALE L.J. 1143 (1979); Alex M. Johnson, Jr., Adding Another Piece to the Financing Puzzle: The Role of Real Property Secured Debt, 24 LoY. L.A. L. REV. 335 (1991); Hideki Kanda \& Saul Levmore, Explaining Creditor Priorities, 80 VA. L. REV. 2103 (1994); Homer Kripke, Law and Economics: Measuring the Economic Efficiency of Commercial Law in a Vacuum of Fact, 133 U. PA. L. REV. 929, 941 (1985) (advocating a practical analysis which leads to the observation that security is desirable because it is quick and offers many procedural advantages); Saul Levmore, Monitors and Freeriders in Commercial and Corporate Settings, 92 YALE L.J. 49 (1982); Lynn M. LoPucki, The Unsecured Creditor's Bargain, 80 VA. L. REV. 1887 (1994); Randal C. Picker, Security Interests, Misbehavior, and Common Pools, 59 U. CH. L. REv. 645 (1992); Alan Schwartz, Security Interests and Bankruptcy Priorities: A Review of Current Theories, 10 J. LEGAL STUD. 1, 9-28 (1981); Alan Schwartz, A Theory of Loan Priorities, 18 J. LEGAL STUD. 209 (1989); Alan Schwartz, Taking the Analysis of Security Seriously, 80 VA. L. REV. 2073 (1994); Alan Schwartz, The Continuing Puzzle of Secured Debt, 37 VAND. L. REV. 1051 (1984); Robert E. Scott, A Relational Theory of Secured Financing, 86 COLUM. L. REv. 901 (1986); Paul M. Shupack, Solving the Puzzle of Secured Transactions, 41 RUTGERS L. REV. 1067 (1989); Clifford W. Smith \& Jerold B. Warner, Comment, Bankruptcy, Secured Debt, and Optimal Capital Structure, 34 J. FiN. 247 (1979); Rene M. Stulz \& Herb Johnson, An Analysis of Secured Debt, 14 J. FiN. EcoN. 501 (1985); George G. Triantis, Secured Debt Under Conditions of Imperfect Information, $21 \mathrm{~J}$. LEGAL STUD. 225 (1992); Warren, supra note 90; Lawrence A. Weiss, Bankruptcy Resolution: Direct Costs and Violation of Priority of Claims, 27 J. FIN. ECON. 285 (1990); James J. White, Efficiency Justifications for Personal Property Security, 37 VAND. L. REV. 473 (1984).

404 See Steven L. Harris \& Charles W. Mooney, Jr., A Property-Based Theory of Security Interests: Taking Debtors' Choices Seriously, 80 VA. L. REV. 2021, 2034 (1994) (citing RICHARD A. POSNER, ECONOMIC ANALYSIS OF LAW 13-14 (4th ed. 1992)).

405 See Schwarcz, supra note 403, at 480 (citing Thomas Miceli \& Kathleen Segerson, Defining Efficient Care: The Role of Income Distribution, 24 J. LEGAL STUD. 189, 192-93 (1995)). Professor Schwarcz has added his own twist with the concept of "Pareto class efficiency," which suggests that a legal rule will be "efficient" when viewing each class of persons (e.g., unsecured creditors) affected by the rule as a single, collective person. Schwarcz, supra note 403 , at $432-33$.

406 Although perhaps no concern to economically-oriented advocates of an efficiency analysis, it is worth noting that virtually everything about this set of facts is speculative. How could any of the debtor's creditors-secured or unsecured-know ex ante what she will do with her assets at any given time? The response may be that the efficiency analysis derives from certain assumptions about what "rational" persons would consider to be "greater wealth," and 
Not everyone believes that full priority is an unqualified good. Some have argued that, whether or not efficient, full priority is unfair to "non-adjusting creditors" (involuntary creditors). ${ }^{407}$ Contractual creditors of a debtor that has fully encumbered her property can (and perhaps should) "adjust" to this fact by refusing to extend credit, charging a higher rate of interest, demanding additional contractual protections, etc. The problem, critics would point out, is that not all creditors can, in fact, adjust to the risk imposed on them by full priority for the secured party (which therefore means no priority for them). Non-adjusting creditors most famously include tort creditors who do not "choose" their debtors in any meaningful way and often cannot "adjust" their rights vis-á-vis the debtor.

The response from proponents of full priority might be that, given the choice, most non-adjusting creditors would probably have chosen to have the debtor grant full priority to the secured party anyway. That is, ex ante unsecured creditors (contractual or otherwise) would usually want the debtor to be as highly leveraged as possible. This leverage means, in theory (and perhaps in fact), maximum likelihood of repayment. As Professors Baird and Jackson put it:

\begin{abstract}
"Nonconsensual" creditors, be they tort or tax, would not necessarily want different limits of restraint than would consensual creditors. Indeed, in many respects, their interests in controlling the debtor are identical. As a result, the limits that consensual creditors would impose on investments by a debtor also largely will protect nonconsensual claimants because of the congruence in their interests. $^{408}$
\end{abstract}

how it can be achieved. See Oliver E. Williamson, Transaction Cost Economics, in HANDBOOK OF INDUSTRIAL ORGANZZTION 135 (R. Schmalensee \& R. Willig eds., 1989) (discussing "bounded rationality" of market participants). Professor Schwarcz has observed that wealth is much more clearly created when a security interest is granted to secure a loan of new value, as distinct from an antecedent debt. Schwarcz, supra note 403, at 430 ("New money secured credit ... does not necessarily reduce the assets on which unsecured creditors can levy because the debtor receives the loan proceeds."). This presumes that the loan will roughly equal the value of the collateral. Most lenders, however, seek an equity cushion, an excess of collateral value over the amount of the secured loan. It is not clear that a significantly oversecured loan would be "efficient" with respect to unsecured creditors, individually or as a class.

407 See Bebchuk \& Fried, supra note 403, at 882; LoPucki, supra note 403, at 1897 ('The ability to victimize involuntary creditors may in significant part explain 'why secured credit is such a widespread phenomenon."') (citations omitted); James H. Scott, Jr., Bankruptcy, Secured Debt, and Optimal Capital Structure, 32 J. Fin. 1, 2-3 (1977); Warren, supra note 230, at 1897 ("[I]n a full-priority system, secured creditors win, trade creditors and employees may win or lose, and tort victims lose."). But see Hill, supra note 403, at 1171 ("[E]xtemalization is likely only a small part of the explanation for secured debt.").

408 Douglas G. Baird \& Thomas H. Jackson, Fraudulent Conveyance Law and lts Proper Domain, 38 VAND. L. REV. 829, 835 n.20 (1985). 
Perhaps the $\mathrm{B} / \mathrm{L}^{\infty} \mathrm{s}$ of the world are just another form of non-adjusting creditor: They, too, failed to anticipate the possibility of full priority running in favor of an SP earlier in the chain of production. They would, ex ante, still choose the CIPs Rules because such rules would, in the aggregate, be efficient and thus increase aggregate wealth (meaning the wealth that enabled them to buy or license the collateral in question). Thus, the argument would go, it is unlikely that they are looking for anything other than a windfall from the secured party that made so much wealth possible in the first place.

Are the CIPs Rules efficient? Probably "yes" from the perspective of the secured party, and even the perspective of parties in privity with the debtor, such as the immediate contractual unsecured creditors and owners. These rules certainly enhance the rights of secured parties in collateral of the debtor and therefore should maximize the wealth that the debtor can create with its assets. The CIPs Rules probably increase wealth in the debtor's immediate community where the debtor has disposed of collateral for fair value: The debtor's immediate pool of unsecured creditors are no worse off by this transaction (and are probably better off), and the secured party is in the best position of all, having rights in both the proceeds and, if the statutory cutoffs do not apply, the original collateral as well.

On an aggregate view-a "Kaldor-Hicks" (or "societal") approach—it is not clear. If SP can reach information assets acquired directly or indirectly from $D$ by $\mathrm{B} / \mathrm{L}^{\infty}$, it means most likely that the loss that SP would otherwise suffer has simply been shifted to $\mathrm{B} / \mathrm{L}^{\infty} . \mathrm{B} / \mathrm{L}^{\infty}$ might then become another unsecured, non-adjusting creditor of $\mathrm{D} .{ }^{409}$ In principle, and perhaps akin to warranty theory in negotiable instruments, liability for the loss of $B / L^{\infty}$ would then be pushed back up the chain to the first party to take from the "wrongdoer"- the seller/licensor not in ordinary course. ${ }^{410}$ Is this an efficient shifting of liability? Perhaps, in the same way that

409 The basis for such a claim is opaque. It is not apparent that the transfer warranties applicable to negotiable instruments, which would create a cause of action in analogous circumstances, have a corollary in the case of data, biotechnology assets or other information assets, generally. Indeed, as discussed above, the warranties of a licensor of data will be provided by contract or, perhaps, as discussed above, UCITA-meaning, in most cases, none. As discussed in Part IV.B, supra, UCITA would appear to create no warranty of title. UCITA section 401(a) provides that a licensor of information "warrants that the information will be delivered free of the rightful claim of any third person by way of infringement or misappropriation." This appears not to reach security interests in the information. See also discussion at note 184 , supra.

410 See U.C.C. $\$ \$ 3-416,-417$ (2001) (transfer and presentment warranties as to negotiable instruments). Compare Peltier, supra note 298, at 224 ("To the extent that the purchaser incurs loss by reason of the asserted security interest, recovery may be available against her seller in an action for breach of warranty of good title, but only if that intermediate seller is neither absent nor insolvent.") (citations omitted), with Knapp, supra note 298, at 887 ("if the secured party is successful in pursuing the goods in the hands of the buyer, the dealer 
negotiable instruments' loss-shifting rules are efficient: They shift liability back to the parties that were "in the best position" to prevent the loss. This, presumably, creates an incentive to be more careful in the first place.

What if instead $B / L^{\infty}$ lacks recourse to $D$ (or anyone else) because the contract through which it (directly or indirectly) acquired D's information assets expressly waived warranties or covenants about the state of "title" to, or encumbrances on, these assets? We have seen that such provisions would be enforceable under UCITA and perhaps cases like ProCD.411 Thus, not only would $\mathrm{B} / \mathrm{L}^{\infty}$ not be able to discover the security interest in the information assets it acquires; it would also have waived its contractual right to do anything about it. The loss would therefore be borne by the party in the worst position to protect itself $\left(B / L^{\infty}\right)$.

Here, the efficiency model breaks down. The $B / L^{\infty} s$ of the world will eventually recognize the potential risks created by the CIPs Rules as applied to information assets. A rational response might be to demand contractual protection or to purchase insurance from some third party. The problem, however, is that these protections will either be ineffective or prohibitively expensive. This is because the risk of a prior SP showing up and asserting rights in information assets may or may not be high but will usually be impossible to quantify. The very features that give modern information assets their value-mobility, mutability, and replicability - should, when coupled with the CIPs Rules, pose significant challenges for potential buyers and licensees of these kinds of assets. The response would be simple: Do not buy or license information assets. This result would seem to be the opposite of "efficient."

Acknowledging that efficiency may be difficult, if not impossible, to establish, proponents of full priority also argue that the Article 9 regime simply reflects the general right we all have to enter into contracts and dispose of property. "The legal regime for security interests," Professors Harris and Mooney argue, "reflects property law functionally as well as doctrinally. We believe it follows that the law should honor the transfer or retention of security interests on the same normative grounds on which it respects the alienation of property generally." 412 On this view, full priority is permitted (and perhaps compelled) by "the baseline principles that underlie current law insofar as it generally respects

will be liable to the buyer for breach of a warranty of title, express or implied.") (citing U.C.C. $\S 2-312$ (2001)). See generally WHITE \& SUMMERS, supra note 367, at 357 ("[BIOCOBs] will have a cause of action against [BIOCOB's seller] for breach of warranty of title ... and so on up the line until the "bad guy' is made to pay."). U.C.C. section 2-312(1)(b) provides that a contract for the sale of goods includes "a warranty by the seller that ... the goods shall be delivered free from any security interest or other lien or encumbrance of which the buyer at the time of contract has no knowledge."

411 See discussion in Part IV.B, supra.

412 Harris \& Mooney, supra note 404, at 2051 (footnote omitted). 
the free and effective alienation of property rights and the ability of parties to enter into enforceable contracts." 413 Since a security interest is simply another use of property-and is an "interest in property" according to the statutory definition-we should have very good reasons for limiting the general rule.414

The problem here is that the CIPs Rules exhibit little concern for the contract and property rights of $B / L^{\infty}$. Why, one might ask, should these baseline principles not apply equally to remote buyers and licensees? On what basis are their property and contract rights less meritorious than those of the remote secured party?

A response might reflect the role of notice in secured finance. Harris and Mooney observe that the Article 9 system in fact is not a pure property/contract grab for secured parties. Rather, security interests are effectively limited by requirements of public notice which, in their view, justifies full priority. "[W]e are inclined to favor a filing system that provides public notice of the kind that enables third parties to discover whether particular property may be encumbered," they write, because "the public record effectively can impart useful information about the potential existence of a security interest." 415

Public notice theoretically plays a critical role in rendering security interests effective against remote buyers or licensees. The most common way to "perfect" security interests in most information assets will be via some form of public notice, usually the filing of a U.C.C. -1 financing statement. ${ }^{416}$ This statement will give basic ("inquiry") notice to the world of SP's interest in D's general intangibles (or other property that is collateral). This feature of the Article 9 system is often viewed as justifying the secured party's ability to take property in the hands of the debtor or others. 417

The problem for remote buyers and licensees, as discussed above, is that this notice will rarely be meaningful. As parties remote from D and SP and perhaps $\mathrm{B} / \mathrm{L}^{1}$, they will not have dealt with the debtor, and so would have little or no reason (or ability) to search in the U.C.C. records for security interests in the debtor's property. Yet, it is this "notice" that will assure the secured party of its priority in the information assets acquired. To the extent notice justifies full priority, in other words, it fails to justify the CIPs Rules applied to $B / L^{\infty}$.

413 Id. at 2050.

414 Id. at $2048-53$.

415 Id. at $2057-58$.

416 See U.C.C. \$ 9-310(a) (2001).

417 See, e.g., Douglas G. Baird, Notice Filing and the Problem of Ostensible Ownership, 12 J. LEGAL STUD. 53, 54-55 (1983). 


\section{CIPs Rules and Recent Property Theory-The Strategies of the Anticommons ${ }^{418}$}

The CIPs Rules also do not fare terribly well in the light of recent property theory. Frank Michelman has suggested, ${ }^{419}$ and Michael Heller has developed, ${ }^{420}$ the argument that recognizing too many rights creates an "anticommons" that begets its own kind of tragedy. The profusion and propagation of security interests in information assets may also produce an anticommons, one that may ultimately come back to haunt the secured parties that the system seeks to protect.

"Anticommons property," Michael Heller has argued, "can be best understood as the mirror image of commons property." 421 Commons property has been characterized as "a scheme of universally distributed, all-encompassing privilege[,] . . . a type of regime that is opposite to [private property]."422 In an anticommons, Heller has argued, multiple rights bearers are each endowed with the right to exclude others from a scarce resource, with the result that no one has an effective privilege of use. ${ }^{423}$ In an anticommons, "tragedy" results when "multiple owners each have a right to exclude others from a scarce resource and no one has an effective privilege of use." ${ }^{24}$ The net effect of an anticommons may be a diminished capacity to create wealth, for example by new invention, production, or capital investment.

A defining feature of an anticommons appears to be a fragmentation of rights that paralyzes economic activity. An anticommons does not, according to Heller, require that all members of the polity hold identical rights to exclude all others. ${ }^{425}$ Rather, the anticommons systems he has observed involved the profusion of rights attendant upon the transition from a command to a "market" economy in Russia, or the privatization of high-level biomedical research. ${ }^{426}$ If, for example, a

418 This subtitle is a (bad) pun on Garrett Hardin, The Tragedy of the Commons, 162 SCIENCE 1243, 1244-45 (1968). (1982).

419 Frank I. Michelman, Ethics, Economics and the Law of Property, in 24 NomOs 3, 6

${ }^{420}$ Michael A. Heller, The Tragedy of the Anticommons: Property in the Transition from Marx to Markets, 111 HARV. L. REV. 621, 633-40 (1998).

421 Michael A. Heller, The Dynamic Analytics of Property Law, 2 THEORETICAL INQ. L. 79, 87 (2001).

422 See Michelman, supra note 419, at 9.

423 Heller, supra note 420 , at 624 .

424 Id.

${ }^{425}$ Heller, supra note 421 , at 89 ("[T]o have an anticommons I do not require that everyone hold rights of exclusion, but only that a limited group of owners be able to block one another.").

426 See Heller \& Eisenberg, supra, note 43 (arguing that biomedical research has been "moving from a commons model toward a privatization model" and that "[a] proliferation of 
few firms (e.g., Celera Genomics) control the "gatekeeper" patents to the human genome, it is easy to see that those who wish to develop biotechnology assetsdrugs, organs, tissues, etc.-may have to license rights under these foundational patents.

It is, by analogy, easy to see that security interests in information assets created under the CIPs Rules may well create an anticommons problem-one that may pose even greater problems for certain SPs than for $B / L^{\infty}$. As information assets pick up and retain more and more CIPs security interests, increasing numbers of SPs will have competing security interests in the same (or derivative) information assets. True, the distribution of rights will become increasingly fragmented. Yet, SPs will nevertheless have rights to exclude (or dilute the rights of) one another in ways that may be material but difficult to predict. At some point, SPs should realize that, by virtue of the reach and breadth of the CIPs Rules and the mobility, mutability, and replicability of information assets, they all have (or will have) Article 9 security interests in all or most existing information assets. In other words, they all have (or will have) the anticommons problem-the right to exclude one another.

Then what?

\section{RESPONSES}

If the CIPs Rules create the kinds of problems described for information assets, there might be several responses. Some will doubtless dismiss these problems as academic hand-wringing. Others may argue that the best solution is legislative, although that would be unrealistic given the nature of the uniform laws enactment process. I consider these alternatives, and conclude that a judicial solution oriented around the nature of the property interest in question may be the best way to protect the reasonable expectations of $\mathrm{B} / \mathrm{L}^{\infty}$ and $\mathrm{SP}$, notwithstanding the force of the CIPs Rules.

\section{A. What Problem?}

Some will object to the foregoing, and argue that remote control problems will be de minimis, and should not concern us. While problems occasionally cropped up under former Article 9, they were sufficiently infrequent to warrant a change in approach. Indeed, as to more traditional forms of collateral-goodssome might argue that making U.C.C. section 9-315(a)'s Rule of Continuity subject to the entrusting limitations of U.C.C. section 2-403(2) renders the "his seller" aspect of the problem a nullity. And, while new technologies and new markets may pose theoretical problems, these problems will be unlikely to make

intellectual property rights upstream may be stifling life-saving innovations further downstream"). 
themselves manifest because it will be a long time before lenders actually lend against these kinds of assets.

Moreover, even if lenders do take security interests in these assets (intentionally or otherwise), they will never pursue their rights and remedies to the fullest because they never have, and probably never will. Their expectations simply do not reach $B / L^{\infty}$. The quotation at the opening of this article about security interests in one's breakfast cereal may have reflected a correct reading of the law at the time, but did not describe real commercial behavior. Even if everything in the world was, by virtue of the CIPs Rules, encumbered in overt or covert ways, it did not matter. Mostly, secured parties were not (and are not) interested in taking breakfast cereal out of our mouths.

A similar line of objection would observe that parties that care about this always have a simple solution: contract. In the same way that contract can restrain negotiability, it can also promote it, if the party with a stake in the problem$\mathrm{B} / \mathrm{L}^{\infty}$ - has the fortitude to negotiate negative covenants and warranties from its seller/licensor. Thus, like tenants in large commercial office buildings, $\mathrm{B} / \mathrm{L}^{\infty}$ would seek, and D and SP should readily give, a "non-disturbance" covenant, whereby they agree not to interfere with the rights of $B / L^{\infty}$ so long as it is current on its license payments.

These objections ignore the metastatic alchemy of applying the CIPs Rules to hyperkinetic information assets. As demonstrated above, security interests can readily attach to information assets unbeknownst to the immediate parties to any given information transaction, through the proceeds rules, the continuity of interest rules, or some combination thereof. As these information assets multiply, transform, and travel, the CIPs security interest will follow along, into computers and biological products remote from the original creator of the information. How could D or SP ever give a meaningful covenant that a database or software license was, in fact, truly unencumbered? How could a wary $B / L^{\infty}$ ever accept such a promise? If the CIPs Rules work as written, these parties will never know who the ultimate SP is, but they will have good reason to worry.

The worry should stem partly from the novelty of the problem and partly because there has been no effective theoretical response to the excesses of the CIPs Rules. ${ }^{427}$ Moreover, to claim that there is no problem is to call into question the merits of the remedy. If secured parties in fact rarely need to pursue remote third parties, why should the statute entitle them to do so, especially when the remedy appears duplicative of other remedies (e.g., fraudulent conveyance) that are more sensitive to the equities of the given case?428

427 This is not to say that the criticisms of the "his seller" rule set forth above lack merit. They could not have considered the application of the CIPs Rules to the information assets considered in this article.

${ }^{428}$ See discussion in Part VI.A, supra. 
One might take an intermediate position and acknowledge that there could be a problem, but the "equitable" exception of U.C.C. section 1-103 will preclude the worst abuses. U.C.C. section 1-103 provides that "unless displaced by the particular provisions of this Act, the principles of law and equity... shall supplement its provisions." Exerting remote control would certainly strike most $\mathrm{B} / \mathrm{L}^{\infty} \mathrm{S}$ as inequitable. By purchasing for value and in good faith, one does not reasonably expect to have to return what was purchased, pay again, or pursue a damage claim against the seller.

Unfortunately, as David Gray Carlson has observed, "[t]he trouble with section $1-103$ is that if rules outside the U.C.C. are available by this means to destroy security interests, [the Rule of Effectiveness] has no meaning at all."429 It is difficult to imagine a court concluding that the Rule of Effectiveness, the Rule of Continuity and the "his seller/licensor" rules, although perhaps "inequitable" in application, were not "particular provisions" of the U.C.C. that "displaced" external notions of fairness. Indeed, the 1992 PEB Report suggested that the revised Article 9 drafting committee "give serious consideration to revising the official comments or issuing PEB Commentary to point out the risks of using equitable principles to reorder Article 9 priorities ...."430 Although U.C.C. section 1-103 has not yet been neutered in this way, it would seem to offer little comfort to the remote buyers and licensees of the future. ${ }^{431}$

\section{B. Legislative Solutions}

Analytically, the easiest solutions are legislative. One could solve the problem of remote control simply by reforming the ordinary course rules to comply with the stronger forms of negotiability more common elsewhere in commerce. Thus, an ordinary course $\mathrm{B} / \mathrm{L}$ would simply be a person who acquired rights in the subject property for value, in good faith, and without notice of claims or defenses to the underlying information asset. One could then excise the

429 See David Gray Carlson, Death and Subordination Under Article 9 of the Uniform Commercial Code: Senior Buyers and Senior Lien Creditors, 5 CARDOzo L. REV. 547, 564 (1984). "To the contrary," he continues, "it seems as if [former] section 9-201 'displaces' such non-UCC rules, within the meaning of section 1-103, making section 1-103 useless to solve the fraudulent conveyance problem." Id. The fraudulent conveyance problem to which Professor Carlson referred was that, if one took the Rule of Effectiveness seriously, then the grant of a security interest that otherwise constituted a fraudulent conveyance would not be avoidable under, e.g., the Uniform Fraudulent Conveyance Act or the Uniform Fraudulent Transfer Act. Id.; see also supra note 231. Presumably, the same would be true for the other problems posed by the CIPs Rules, including the rights of remote takers of collateral.

430 PEB REPORT, supra note 271, at 24.

431 Article 1 of the U.C.C. is currently undergoing a revision, although it would not seem likely that secured parties would readily agree to a modification that reduced the breadth and depth of Article 9 protection. 
"created by his seller/licensor" rules of U.C.C sections 9-320 and -321. The practices of the seller/licensor would no longer dominate the BIOCOB/LIOCOB determination. One should, perhaps, consider limiting the definition of proceeds to those "received by" the debtor, although this may be asking too much.

Unfortunately, as many others have amply demonstrated, legislative change in the commercial arena is subject to "interest group capture." 432 It is highly unlikely that the organizations that draft revisions to the U.C.C.-the PEB, the ALI, NCCUSL_-will have any interest in this issue in the near future, having just finished revising Article 9. Even if they were persuaded of the merits of the problem, it is unlikely that the lending community would tolerate these changes. The problem, at least at this stage, is probably too theoretical to be compelling to most legislatures.

\section{Judicial Solutions}

Unless and until there is a legislative solution, courts run the risk of facing the problem of remote control without rules likely to produce a fair result. Courts that recognize the problem of remote SP control of information assets will likely want to do something about it. One way to restrict remote control, and thus improve the negotiability of information, is via the definition of "property." We tend to assume that many of the more modern assets-information technologies and biotechnologies-are species of property. But, if these assets are not "property," then a security interest in them would not be possible: By definition, a "security interest" is an interest in "personal property." 433 It is therefore axiomatic that, if the assets in question are not "property," no security interest-in the original collateral or proceeds--is possible. ${ }^{434}$

432 Iain Ramsay, Comment, The Politics of Commercial Law, 2001 WIS. L. REV. 565; Edward J. Janger, Predicting When the Uniform Law Process Will Fail: Article 9, Capture, and the Race to the Bottom, 83 IOWA L. REV. 569 (1998); Kathleen Patchel, Interest Group Politics, Federalism, and the Uniform Law Process: Some Lessons From the Uniform Commercial Code, 78 MiNN. L. REv. 83 (1993); Edward L. Rubin, Thinking Like a Lawyer, Acting Like a Lobbyist: Some Notes on the Process of Revising UCC Articles 3 and 4, 26 LOY. L.A. L. REV. 743 (1993); Alan Schwartz \& Robert E. Scott, The Political Economy of Private Legislatures, 143 U. PA. L. REv. 595 (1995); Robert E. Scott, The Politics of Article 9, 80 VA. L. REV. 1783 (1994).

433 U.C.C. § 1-201(37) (2001).

434 There has recently been some movement toward understanding the relationship between "property," more generally, and security interests, more particularly. See Carl S. Bjerre, Secured Transactions Inside Out: Negative Pledge Covenants, Property and Perfection, 84 CoRnell L. REv. 305, 353 (1999); Thomas W. Merrill \& Henry E. Smith, The Property/Contract Interface, 101 CoLUM. L. REv. 773, 833-42 (2001) (arguing that security interests are highly disaggregated rights capable of being understood in both contractual and property terms). 
Even on a fairly simple doctrinal analysis, it is not certain that all information assets are "personal property." There is no question that some of the more traditional forms of intellectual property-copyright and patent-are. ${ }^{435} \mathrm{But}$ it is also clear that nonexclusive licenses of copyrights and patents are not. A nonexclusive license is said to transfer no "property" interest, but consists merely of permission to use the intellectual property, or perhaps a waiver of the licensor's right to sue for infringement. ${ }^{436} \mathrm{~A}$ similar premise exists in licenses that do not relate to intellectual property rights, but that, for example, convey a right to use a database or other property of the licensor. ${ }^{437}$ Nor would we say that trademarks, by themselves, are property; they are transferable only with the "good will" of the business that they represent. ${ }^{438}$

As discussed in Part IV.A, above, there is currently a vigorous debate about whether, and if so, to what extent, personal information about spending habits, credit limits, health, and so on, is "property" of the subject (or of anyone else). I do not, in an article on somewhat technical provisions of the U.C.C., propose to answer these serious questions. I would simply note that most of the discussions about whether these kinds of assets are "property" mask the deeper normative questions about who gets to use these assets and for what purposes.

The logic seems to be, "if it is property, then it is alienable/marketable." But this may be backwards. It may be that property is simply the conclusion that follows from the more difficult determination that we should (or should not) recognize exclusive and/or economically valuable rights to information, which rights can then be sold or licensed (negotiated) for a profit. Consumer data are property in the hands of an etailer, but not of the subject, because the etailer can

43517 U.S.C. $\S 201$ (d)(1) (1994) ("The ownership of a copyright may be transferred ... as personal property."); 35 U.S.C. $\$ 261$ ("[P]atents shall have the attributes of personal property.").

436 See Harris v. Emus Records Corp., 734 F.2d 1329 (9th Cir. 1984) (copyright license); In re Alltech Plastics, Inc., 71 B.R. 686 (Bankr: W.D. Tenn. 1987) (patent license); 17 U.S.C. $\S 101$ (1994); see also WARD, supra note $169, \S 2: 29$, at 2-83 ("[A] license is usually just a contractual promise of immunity from an infringement suit.").

437 See Ticketron Lid. Partnership v. Flip Side, Inc., No. 92-C-091 1, 1993 WL 214164 (N.D. Ill. June 17, 1993).

438 Compare United Drug Co. v. Theodore Rectanus Co., 248 U.S. 90, 97 (1918) ("There is no such thing as property in a trade-mark except as a right appurtenant to an established business or trade in connection with which the mark is employed."), and Rock \& Roll Hall of Fame \& Museum, Inc. v. Gentile Prods., 71 F. Supp. 2d 755, 758 (N.D. Ohio 1999) (same as above) (quoting United Drug, 248 U.S. at 97), with 17 U.S.C. § 201(d)(1) (1994) ("The ownership of a copyright may be transferred ... as personal property."), and 35 U.S.C. § 261 (1994) ("[P]atents shall have the attributes of personal property."). See also Visa U.S.A., Inc. v. Birmingham Trust Nat'l Bark, 696 F.2d 1371, 1375 (Fed. Cir. 1982) ("'A] mark may be transferred only in connection with the transfer of the goodwill of which it is a part. A naked transfer of the mark alone--known as a transfer in gross-is invalid."). 
sell it and the subject cannot object. Cell lines are property in the hands of the doctor, but not the donor patient, because the doctor, as "inventor," obtained the patent. ${ }^{439}$

No single theory yet explains when or under what circumstances information should be property. Indeed, it is not clear that such a theory could develop or would be meaningful. "Information," like "property," is a broad and malleable term. Nevertheless, it is clear that commercial pressure to permit free negotiation is mounting. The existing property, contract, and regulatory regimes set forth in Part IV above are only roughly equipped to distribute property rights in information in ways that we would generally consider acceptable. We do not yet have particularly good theories of property or contract or regulation to set the boundaries on the appropriate commercial uses of information, in part because technology and commerce are currently well ahead of the law. Yet it is equally clear that secured parties will, if they understand their rights, exercise significantly greater control over information assets than most of them-or anyone elsewould anticipate.

Recognizing the property-marginal nature of these assets may help to prevent inappropriate windfalls to certain SPs at the expense of $B / L^{\infty} s$. The propertymarginal status of some of these new technology assets appears to have been no impediment to the attachment of a security interest in them. Thus, courts have routinely recognized security interests in trademarks (in gross), trade secrets, and other assets that may not be "property." 440 Similarly, the fact that revised Article 9 contemplates that a security interest may be cut off as to a nonexclusive license of general intangibles suggests that at some point, and contrary to conventional wisdom, someone thought that such a license was "personal property" in which a security interest could be granted.

439 See also the discussion in Part IV.A, supra.

440 See In re Together Dev. Corp., 227 B.R. 439 (Bankr. D. Mass. 1998) (trademark); In re 199Z, Inc., 137 B.R. 778 (Bankr. C.D. Cal. 1992) (trademark); In re Chattanooga ChooChoo Co., 98 B.R. 792 (Bankr. E.D. Tenn. 1989) (trademark); In re C.C. \& Co., Inc., 86 B.R. 485 (Bankr. E.D. Va. 1988) (trademark); In re Roman Cleanser Co., 43 B.R. 940 (Bankr. E.D. Mich. 1984), aff'd on other grounds, 802 F.2d 207 (6th Cir.1986) (trademark); In re TR-3 Industries, Inc., 41 B.R. 128 (Bankr. C.D. Cal. 1984) (trademark); In re Avalon Software, Inc., 209 B.R. 517 (Bankr. D. Ariz. 1997) (trade secret); United States v. Antenna Systems, Inc., 251 F. Supp. 1013, 1016 (D.N.H. 1966) (trade secret); In re Emergency Beacon Corp., 23 UCC Rep.Serv. (CBC) 766 (S.D.N.Y.1977) ("patent rights, tradename, customer lists, books and records and ... [the] right to manufacture or sell emergency beacons and related electronic equipment are general intangibles within the meaning of [former] \$9-106 of the Uniform Commercial Code."); In re Levitz Ins. Agency, 152 B.R. 693, 697 (Bankr. D. Mass. 1992) (treating customer list as general intangible under former Article 9); see also In re Collecting Concepts, Inc., No. 99-60268-T, 2000 WL 1191026 (Bankr. E.D. Va. Feb. 28, 2002) (property of debtor's estate "includes customer lists"). 
If Article 9 can make property where there is none, it might also be able to strip the "property" out of a security interest created by the CIPs Rules, at least as against remote buyers and licensees. Indeed, if what we are really talking about is $\mathrm{B} / \mathrm{L}^{\infty}$ 's right to use information assets free from the security interests of prior, unknown (perhaps unknowable) secured parties, it would seem that the "property" interests of the prior SP would rarely have a higher economic or moral entitlement than the rights of the remote $B F P\left(B / L^{\infty}\right)$. The right of use in an economically productive fashion is, of course, central to our conceptions of property across categories. ${ }^{441}$ It is difficult to imagine that the rights of a secured party at this level would lead to greater "use value" than would those of the good faith $B / L^{\infty}$. Moreover, it seems exceedingly difficult to identify the basis for concluding that SP should have a "property" interest in the information assets of $\mathrm{B} / \mathrm{L}^{\infty} .442$ No theory of notice, reliance, efficiency, or equity would seem to support such a result. Yet, this is what the CIPs Rules would do.

I suggested in Part VI.C, above that the property rationale for full priority breaks down when applied to the CIPs Rules: Why are the contract and property rights of $B / L^{\infty}$ any less legitimate than those of remote prior lenders? Perhaps these same property notions should be brought to bear to protect $B / L^{\infty} \mathrm{s}$, whether or not they are technically BIOCOBs or LIOCOBs, and whether or not they would be caught by the "his seller" rule. Perhaps that which is property for SP in the hands of D should not be property for the benefit of SP in the hands of $B / L^{\infty}$.

Through an adjustment in the definition of property, then, courts could import the equitable limitations on the CIPs Rules forbidden by a fair reading of U.C.C. section 1-103. It would be economically counterproductive and inequitable to treat exchanged data, or a sub-sub-sublicense of software, or an organ transplant as subject to a CIPs Rule security interest in favor of some remote SP when $\mathrm{B} / \mathrm{L}^{\infty}$, the holder of that bundle of rights (whether or not property), had no notice of the security interest and no reasonable opportunity to learn of it.

Nor is this to leave secured parties without protection. Secured parties that genuinely rely on the value of assets that are highly mobile, mutable, and replicable should, in many instances, be able to mark these assets, in the same

441 See, e.g., Merrill \& Smith, supra note 434, at 372-74 (rights should be created and protected "by specifying certain use rights") (citing R.H. Coase, The Federal Communications Commission, 2 J.L. \& ECON. 1 (1959)). Merrill and Smith refer here to Coase's discussion about the creation, protection and distribution of federally created rights in bandwidth. In his own words, Coase explained that "what is being allocated by the Federal Communications Commission, or, if there were a market, what would be sold, is the right to use a piece of equipment to transmit signals in a particular way. Once the question is looked at in this way, it is unnecessary to think in terms of ownership of frequencies or the ether." Coase, supra at 33.

442 See STEPHEN R. MUNZER, A THEORY OF PROPERTY 24 (1990) ("[P]roperty is indeterminate at the margin."). It is perhaps at this level that Professor Mautner's conclusions about the moral rights of BFPs take on their greatest force. See Mautner, supra note 70, at 149 52 (asserting moral superiority of BFPs). 
way that chattel paper purchasers mark those financial documents to protect against the claim that a later purchaser is a bona fide purchaser who has acquired the paper free of the prior security interest. It seems highly likely that if shrinkwrap licenses can contain pages and pages of terms binding the licensee, they can also contain a simple statement of SP's security interest. $B / L^{\infty}$ s that do not care would then purchase at their peril. ${ }^{443}$

Where the collateral cannot be marked, the decisions will be the most difficult. Still, the equities should favor the remote buyer/licensee. Lenders that care about their collateral have historically had a knack for figuring out how to police the collateral and the debtor. It seems both unfair and unfounded (from a property perspective) to deny the rights of remote parties in favor of secured parties under these circumstances.

\section{CONCLUSION}

The rules on continuity of interest and proceeds under Article 9 have long posed challenges to generally accepted norms about negotiability. Outside the Article 9 system, negotiation of most forms of property to most bona fide purchasers results in a transfer free of prior claims or interests. Article 9, however, makes the creation and continuity of security interests easy and sure-perhaps too much so. In an older economy, where collateral was not as well traveled or as readily multiplied or transformed, Article 9's unusual restraints on negotiation were tolerable. Applied to new forms of collateral-information technologies and bioinformation assets- - the results will be surprising and disturbing.

Unless and until there is a meaningful legislative response, this article has proposed a judicial solution organized around one of the fundamental analytic units in question-property. While information assets may be property for some purposes-including the purpose of initially granting a security interest - there is no good reason that this property interest need be recognized in favor of secured parties against buyers or licensees of this information at a significant remove from the debtor.

443 Article 9's rules on "electronic chattel paper" appear to contemplate this kind of electronic marking. See U.C.C. $\$ 9-105$ (2) (2001) (security interest in electronic chattel paper perfected by control if electronic chattel paper "identifies the secured party as the assignee"). "Electronic chattel paper" is defined as chattel paper (i.e., a monetary obligation coupled with a lease or security interest) "evidenced by a record or records consisting of information stored in an electronic medium." Id. § 9-102(a)(31) (2001). 